\title{
Bioactives from culinary spices and herbs: a review
}

\author{
Milda E. Embuscado \\ McCormick \& Company, Inc., Hunt Valley, MD 21031, USA. E-mail: Milda_Embuscado@mccormick.com \\ DOI: $10.31665 /$ JFB.2019.6186 \\ Received: June 15, 2019; Revised received \& accepted: June 26, 2019 \\ Citation: Embuscado, M.E. (2019). Bioactives from culinary spices and herbs: a review. J. Food Bioact. 6: 68-99.

\begin{abstract}
Culinary spices and herbs have been used in food and beverages to enhance aroma, flavor, and color. They are rich in phytochemicals that provide significant antioxidant and anti-inflammatory effects. There is growing interest in identifying compounds from spices and herbs responsible for modulating oxidative and inflammatory stress to prevent diet-related diseases. This contribution will provide an overview of culinary spices and herbs, their classification, their sources or origins and more importantly, their chemical composition, antioxidant activity and their impacts on human health based on important and recent studies.
\end{abstract}

Keywords: Spices; Herbs; Antioxidants; Anti-inflammatory; Bioactives.

\section{Introduction}

Plants are major sources of food bioactives. Spices and herbs are plant materials that provide a wide range of biologically active compounds. In addition to being used as sources of aroma, flavor, and color and as preservatives, spices and herbs have been used for medicinal purposes and for health and wellness for centuries. The term bioactive is derived from the phrase biologically active which indicates that the substance has a positive effect on living organism, tissue or cell. Bioactive molecules are compounds that play an important role in human growth and development and have proven health benefits. They also amend disease risks by easing disease conditions. The National Institutes of Health (NIH) defines bioactive food components as "constituents in foods or dietary supplements, other than those needed to meet basic human nutritional needs, which are responsible for changes in health status." In the classical sense, bioactives are not nutrients. They are not essential for life but likewise perform essential functions: (1) they influence physiological or cellular activities which result in beneficial health effects, (2) they amend disease risk, rather than preventing deficiency diseases, and (3) they act as inducers and inhibitors of enzymes, inhibitors of receptor activity, and inducers and inhibitors of gene expression (Koe et al., 2014). In this respect, the absorption and bioavailability of bioactives present must also be considered (Shahidi and Peng, 2018).

Probiotics, phytosterols, lutein, lycopene, fatty acids and pep- tides are some examples of bioactive substances. Bioactives also include antioxidants such as polyphenols, carotenoids and nonflavonoid phenolics. Antioxidants protect the human body from oxidation brought about by free radicals, superoxide and other oxygen radicals as well as other substances that trigger oxidation. Bioactives can be classified into several groups based on their function, molecular structure or source. Table 1 summarizes the different groups, examples from each group, food sources, their functions and related publications. Note the diverse health benefits derived from these bioactives, from blocking low-density lipoproteins and cholesterol, antioxidant activity, anticancer to improving cardiovascular, joint and digestive health and strengthening immunity. Three out of seven different groups of bioactives are supplied by spices and herbs. Epidemiological studies indicate that cancer incidence in countries such as India where spices are consumed daily is much lower $(94 / 100,000)$ than those where spices are not consumed such as United States $(318 / 100,000)$ suggesting the potential role of spices in cancer prevention (Kunnumakkara et al., 2018). Food bioactives from top spices and herbs will be reviewed in this contribution paper based on significant scientific studies and recent findings.

\section{Spices and herbs}

The value and volume of spices being produced continue to increase by about $5 \%$ annually (Fig. 1a). The total world imports 


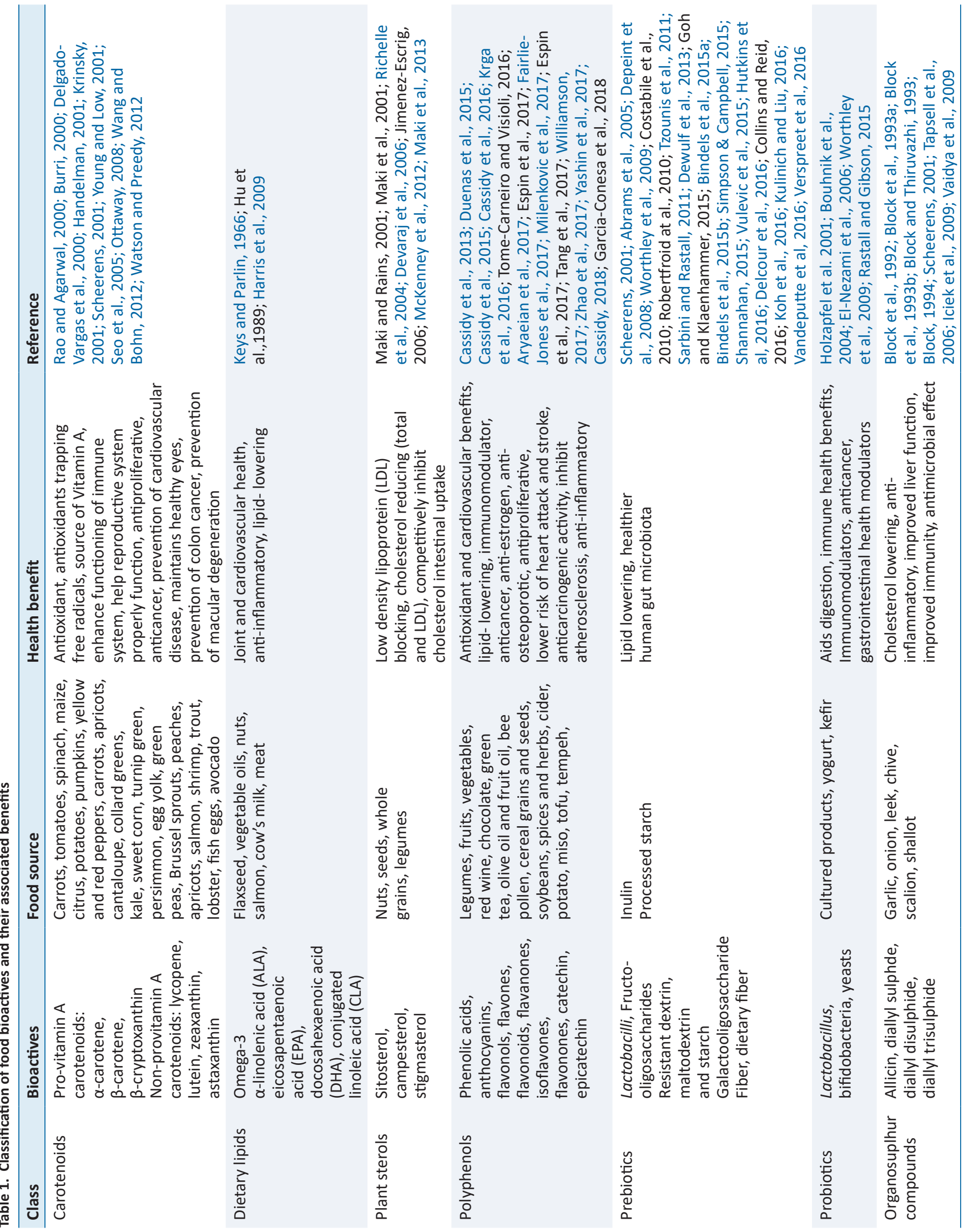



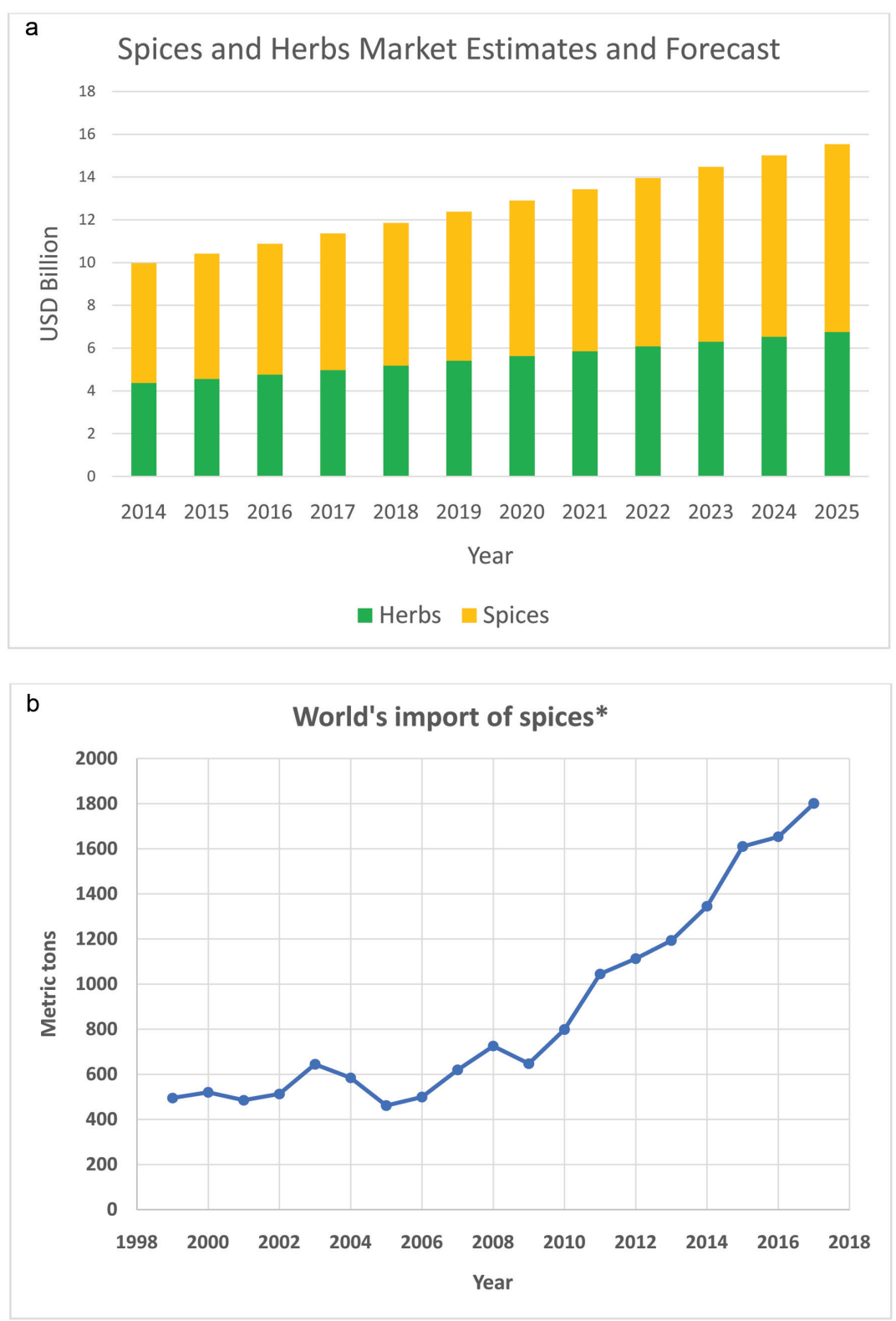

Figure 1. (a) Spices and herbs global market estimates and forecast (Varma, 2019); (b) World's import of spices (Source: USDA, www.fas.usda.gov).

from spices and herbs producing countries increased significantly from 1999 to 2017 (Fig. 1b). This is due to the growing popularity of using spices and herbs as natural and clean label ingredients and sources of aroma, flavor and color. Their popularity is also increasing due to the health benefits and therapeutic effects derived by including spices and herbs in personal diets. In fact, the Mediterranean diet includes herbs and spices with the whole grains, fruits, vegetables, beans and healthy fats and oils (e.g., olive oil) (Mayo Clinic, 2019). This provides a well-recognized healthy diet that reduces the risk of heart disease and lowers the level of oxidized low-density lipoprotein (LDL) cholesterol. The Mediterranean diet is also associated with reduced incidence of cancer, Parkinson's and Alzheimer's diseases (Mayo Clinic, 2019). Table 2 shows the sources of the spices and herbs in the world and the plant parts where they come from. Asia and the Middle East dominate produc- tion of most spices and herbs.

\section{Different product forms of selected spices and herbs}

Spices and herbs are commercially available to consumers in different forms (Table 3). Most spices and herbs when dried are available in ground or powder form. Some are freshly milled before use like whole black pepper when used in some dishes such as salads or soups as the aroma and flavor are retained better when not pre-milled. The white pepper comes from the black peppercorn in which the black pericarp or husk has been removed by soaking and fermenting the mature black pepper in water. This is to differentiate the black pepper from the white pepper which is also a popular spice because of its unique flavor and pungency. Extracts of spices 
Table 2. Major spices for world trade

\begin{tabular}{|c|c|c|c|}
\hline Spices/herbs & Scientific name & Part of plant & Top producer \\
\hline Pepper & Piper nigrum & Berries & $\begin{array}{l}\text { Indonesia (whole pepper); } \\
\text { India (crushed/ground pepper) }\end{array}$ \\
\hline Capsicums & $\begin{array}{l}\text { Capsicum annuum var annuum; } \\
\text { C. chinense; } C \text {. frutescen }\end{array}$ & Fruits & China \\
\hline Nutmeg/mace & Myristica fragrans & $\begin{array}{l}\text { Kernel of the seed; Net-like crimson } \\
\text { leathery outer growth or aril }\end{array}$ & Guatemala \\
\hline Cardamon & $\begin{array}{l}\text { Elettaria cardamomum; } \\
\text { E. major; E speciosa }\end{array}$ & Fruits & Guatemala \\
\hline Allspice/pimento & Pimenta dioica & Berries & \\
\hline Vanilla & $\begin{array}{l}\text { Vanilla planifolia (Mexican); V. pompona } \\
\text { (West Indies); V. tahitensis (Tahitian) }\end{array}$ & Beans & Madagascar \\
\hline Cloves & Syzygium aromaticun & Buds & Indonesia \\
\hline Ginger & Zingiber officinale & Rhizome & China \\
\hline Cinnamon/cassia & $\begin{array}{l}\text { Cinnamomum verum (Sri Lanka); } \\
\text { C. cassia (China); C. burmannii } \\
\text { (Indonesia); C. loureirii (Vietnam) }\end{array}$ & Bark & $\begin{array}{l}\text { Sri Lanka (whole cinnamon); } \\
\text { Indonesia (crushed/ } \\
\text { ground cinnamon) }\end{array}$ \\
\hline Turmeric & Curcuma longa & Rhizome & India \\
\hline Saffron & Crocus sativus & Stigma & Iran \\
\hline Coriander & Coriandrum sativum & Fruit & Morocco, India \\
\hline Cumin & Cumimum cyminum & Fruit & India, Syria, Turkey \\
\hline Mustard & $\begin{array}{l}\text { Sinapis alba (white mustard); } \\
\text { Brassica juncea (Indian mustard) }\end{array}$ & Seeds & Syria \\
\hline Sesame seeds & Sesamum indicum & Seeds & Nepal, Canada, Myanmar \\
\hline Sage & Salvia officinalis & Leaf & Turkey \\
\hline Oregano & Origanum vulgare & Leaf & Turkey \\
\hline Thyme & Thymus vulgaris & Leaf & Iran \\
\hline Bay leaf & Laaurus nobilis & Leaf & Iran \\
\hline Mints & Mentha arvensis; M. spicata; M. gracilis & Leaf & India, China \\
\hline
\end{tabular}

Tabulated based on information from UNIDO and FAO (2005).

and herbs are also available for specific markets. Some parts of the world like Europe, the Mediterranean region and Asia use fresh herbs in their cuisine.

\section{Classification of spices and herbs}

Herbs come from leaves of a plant while spices come from different parts of a plant other than the leaves (Table 4). Spices and herbs can be classified into various groups based on flavor/taste, taxonomy or part of the plant where they came from. Based on flavor or taste, spices and herbs can be classified into 4 groups: hot spices (black and white peppers, Cayenne pepper, mustard, chillies), mild flavor spices (paprika, coriander), aromatic spices (clove, cumin, dill fennel, nutmeg, mace, cinnamon) and aromatic herbs and vegetables (thyme, basil, bay leaf, marjoram, shallot, onion, garlic).

Based on taxonomic classification, spices and herbs fall under the class Angiospermae or the flowering plants. The taxonomic classification is illustrated in Table 5 and shows the taxonomic relationship of the different spices and herbs. Spices and herbs have been used for medicinal purposes for centuries and are one of the best sources of food bioactives functioning as natural antioxidants because they contain potent compounds that have been shown to impart antioxidative effects when consumed and when added in foods prone to oxidation such as fats and oils.

\section{Phytochemistry}

Phytochemicals constitute a large group of bioactives derived from plants. This group consists of flavonoids, non-flavonoid phenolic compounds, carotenoids, plant sterols, glucosinolates and other sulphur-containing compounds. There are more than 6,000 different flavonoids that have been described and this continues to grow upon discovery of new compounds (Harborne and Williams, 2000). Flavonoids are polyphenolic compounds that consist of 15 carbons, with 2 aromatic rings connected by a 3-carbon bridge (Jaganath and Crozier, 2010). Figure 3 shows the basic molecular structures of flavonoids. Table 6 contains a summary of the different classes within the spice and herb bioactives. Plants produce 
Table 3. Spices and herbs available to consumers

\begin{tabular}{|c|c|c|c|c|}
\hline Spice/Herb & Species & Common name & Description & $\begin{array}{l}\text { Forms available } \\
\text { in the market }\end{array}$ \\
\hline Black pepper & Piper nigrum & black pepper, pepper & $\begin{array}{l}\text { Black and round with rough surface } \\
\text { about } 2-3 \mathrm{~mm} \text { in diameter }\end{array}$ & Whole, ground \\
\hline White pepper & Piper nigrum & white pepper & $\begin{array}{l}\text { White or off white and round } \\
\text { about } 2-3 \mathrm{~mm} \text { in diameter; this } \\
\text { is actually the black peppercorn } \\
\text { which have been fermented and the } \\
\text { black pericarp has been removed }\end{array}$ & Whole, ground \\
\hline Chili pepper & Capsicum annuum & $\begin{array}{l}\text { chile, chile pepper, chilli } \\
\text { pepper, or chilli }\end{array}$ & $\begin{array}{l}\text { Elongated fruit green when } \\
\text { immature and turns to red, yellow, } \\
\text { deep purple, orange in color } \\
\text { when ripe depending on variety } \\
\text { and used in dishes to add heat }\end{array}$ & $\begin{array}{l}\text { Whole, fresh or } \\
\text { dry chili pepper, } \\
\text { dried flakes, } \\
\text { crushed, powder }\end{array}$ \\
\hline Cinnamon & $\begin{array}{l}\text { Cinnamomum verum } \\
\text { (C. zeylanicum); } \\
\text { C. cassia Presl (C. } \\
\text { aromaticaum); } \\
\text { C. burmannii; C. } \\
\text { loureirii Nees; } \text { C. } \\
\text { tamala (Buch.-Ham.) } \\
\text { Nees \& Eberm }\end{array}$ & $\begin{array}{l}\text { True or Ceylon cinnamon, } \\
\text { Mexican cinnamon; } \\
\text { Cassia, Chinese cinnamon; } \\
\text { Indonesian cassia, Korintje } \\
\text { cinnamon, Pandan cinnamon; } \\
\text { Vietnamese cassia, Saigon } \\
\text { cinnamon, Vietnamese } \\
\text { cinnamon; Indian cassia }\end{array}$ & $\begin{array}{l}\text { Very thin, light yellow brown } \\
\text { smooth bark, less dense, more } \\
\text { crumbly texture, highly fragrant } \\
\text { aroma, more aromatic in flavor; } \\
\text { Lower levels of coumarin (Figure 2); } \\
\text { Much stronger and harsher flavor } \\
\text { than Ceylon cinnamon, medium } \\
\text { to light reddish brown, hard and } \\
\text { woody, thicker bark (Figure 2) }\end{array}$ & $\begin{array}{l}\text { Ground, stick, } \\
\text { chips, extract }\end{array}$ \\
\hline Fenugreek & $\begin{array}{l}\text { Trigonella foenum- } \\
\text { graecum }\end{array}$ & fenugreek & $\begin{array}{l}\text { Small green oblong leaves } \\
\text { with maple syrup smell }\end{array}$ & Dry, powder \\
\hline Garlic & Allium sativum & garlic & $\begin{array}{l}\text { Spear-shaped beige in color } \\
\text { with pungent odor }\end{array}$ & $\begin{array}{l}\text { Fresh, dry, powder, } \\
\text { flakes, granules }\end{array}$ \\
\hline Ginger & Zingiber officinale & ginger & Yellow fragrant rhizome & $\begin{array}{l}\text { Fresh, dry, powder, } \\
\text { flakes, granules }\end{array}$ \\
\hline Rosemary & $\begin{array}{l}\text { Rosmarinus } \\
\text { officinalis L }\end{array}$ & rosemary & $\begin{array}{l}\text { Fragrant needle-like green leaves } \\
\text { from an evergreen plant }\end{array}$ & $\begin{array}{l}\text { Fresh whole or } \\
\text { dry leaf, crushed, } \\
\text { powder, extract }\end{array}$ \\
\hline Turmeric & Curcuma longa & turmeric & $\begin{array}{l}\text { Deep orange yellow rhizome with a } \\
\text { warm, bitter, hot and earthy flavor }\end{array}$ & $\begin{array}{l}\text { Fresh, dry, powder, } \\
\text { flakes, granules }\end{array}$ \\
\hline Vanilla & Vanilla planifolia & vanilla & $\begin{array}{l}\text { Long, greenish-yellow seed } \\
\text { pods when harvested that turn } \\
\text { to dark brown after curing }\end{array}$ & $\begin{array}{l}\text { Vanilla beans, } \\
\text { vanilla paste, vanilla } \\
\text { extract, vanilla } \\
\text { extract concentrate }\end{array}$ \\
\hline
\end{tabular}

these substances to defend themselves against various agents in the environment for survival and adaptation. The roles of phenolics and flavonoids include structural roles supporting or protecting tissues, involvement in defense strategies, as attractants for pollinators and seed-dispersing animals, and as allelopathic agents, ultra violet (UV) protectants and signal molecules in the interactions between plants and their environment (Jaganath and Crozier, 2010). The anthocyanins protect chloroplasts from photodegradation by absorbing high-energy quanta, while scavenging free radicals and reactive oxygen species (ROS) (Gould, 2004). These phytochemicals provide similar invaluable benefits to humans by modulating human metabolism in a manner favorable for the prevention or reduction in the risk of degenerative diseases such as cardiovascular diseases, diabetes, obesity and cancer (Anderson et al., 1999).

The aromatic herbs in the mint family contain a significant amount of effective antioxidants (Table 7) together with the other herbs in the mint family. In fact, these herbs are used as antioxi- dants in food to prevent development of rancidity and to improve the shelf life of oils and cosmetics. It is particularly effective in enhancing the stability of omega- 3 rich oils. Table 8 summarizes the effectiveness of rosemary or rosemary-derived products in preventing oxidation in foods and production of deleterious compounds during high temperature cooking. This table also listed some of the recent findings on the health benefits of consuming rosemary and other spices and herbs. Since rosemary has been found to be a very effective antioxidant, a number of natural and clean label antioxidants derived from rosemary are now commercially available. It is the main and significant raw material for the manufacture of antioxidants that are used in food and food products. Added benefits of using rosemary or extracts from rosemary are: (1) product is natural or from a natural source (2) clean label (3) long history of safe usage (4) non-GMO and (5) the organic variety is generally available. All these qualities and added benefits from rosemary are what consumers are looking for in food ingredients. 


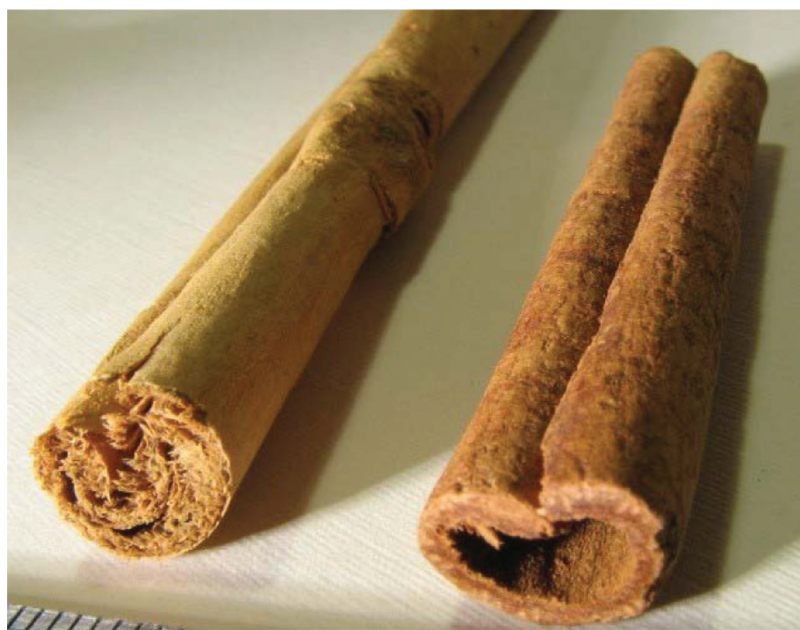

Figure 2. Left: Cinnamomum verum, right: $C$. burmannii-note the structural and color differences between these two species.

\section{Biological activities}

Figure 4 summarizes the significant effects and mechanism of action of curcumin, a potent bioactive from turmeric. This also sums up and reflects some of the overall health benefits and positive effects of bioactive compounds from spices and herbs on the human body such as an antioxidant, an anti-inflammatory, an anti-amyloidogenic, neuroprotective as well as enhancing effect on cognition (Shahidi and Hossain, 2018).

\section{Mechanism of action as an antioxidant}

The free radicals such as $\mathrm{R} \cdot \mathrm{RO} \bullet$ (alkoxyl radical), $\mathrm{ROO} \bullet$ (peroxyl radical), $\mathrm{O}_{2}-$ (superoxide radical anion), $\mathrm{H}_{2} \mathrm{O}_{2}$ (hydrogen peroxide), $\mathrm{OH}^{-}$(hydroxyl radical), $\mathrm{ROOH}$ (organic hydroperoxide) are constantly being produced in the body due to normal metabolic processes and due to exposure to environmental stressors such as exposure to ozone, industrial chemicals, air pollutants, smoking, UV light and radiation, among others. A appropriate balance between free radicals and antioxidants is necessary for proper physiological function (Lobo et al., 2010). If there is excessive free radicals in the body, then lipids, proteins and DNA are adversely affected which can trigger a number of diseases such as diabetes, cancer, heart disease and neurodegenerative

Table 4. Sources of spices and herbs

\begin{tabular}{ll}
\hline Part of the plant & Spice/Herb \\
\hline Leaves & Basil, oregano, bay leaf, thyme, tarragon \\
Bark & Cinnamon, cassia \\
Seed & Fennel, fenugreek, dill mustard \\
Flower/bud, pistil & Clove, saffron \\
Fruits/berries & Clove, chilli, black pepper, allspice \\
Bulbs & Onion, garlic, leek \\
Root & Ginger, turmeric \\
Aril & Mace \\
\hline
\end{tabular}

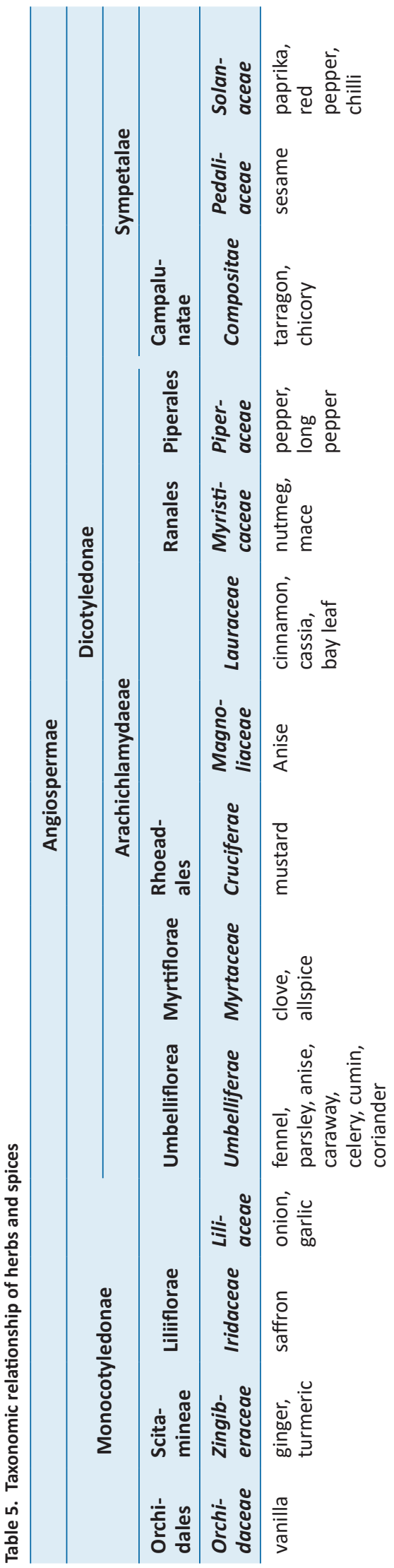


<smiles>[R]OC(=O)/C=C/c1ccc(O)c(O)c1</smiles><smiles>[R]OC(=O)C(C)C([R])O[R]</smiles><smiles>[R][R]C1CCCC1O[R]</smiles>

Phenolic acids
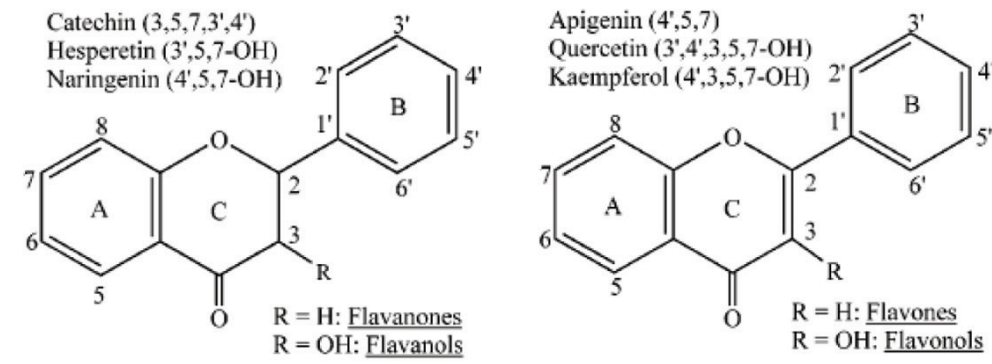

Flavonoids<smiles></smiles><smiles>CCO[C@H]1c2cc(C(C)C)c(O)c(O)c2[C@@]2(C=O)CCCC(C)(C)[C@@]1(C)O2</smiles>

Phenolic diterpenes<smiles>C=CCc1ccc(O)c(OC)c1</smiles>

$\underline{\text { Volatile oils (aromatic compounds) }}$

Figure 3. Structures of major phenolic compounds identified in spices and herbs. Reprinted with permission from Shan et al., (2005) American Chemical Society. 
Table 6. Classification of phytochemicals from spices and herbs

\begin{tabular}{|c|c|c|c|}
\hline Structural classes & Examples & Color & Spices and herbs \\
\hline Flavanols & $\begin{array}{l}\text { Quercetin, quercetin-3-O-rutinoside, myricetin, } \\
\text { kaempferol, isorhamnetin, gingerol }\end{array}$ & White to yellow & Onions, ginger \\
\hline Flavan-3-ols & $\begin{array}{l}\text { Catechin, epicatechin, epigallocatechin, } \\
\text { epigallocatechin gallate, proanthocyanidins }\end{array}$ & & Mint basil, rosemary, sage, dill \\
\hline Flavones & $\begin{array}{l}\text { Apigenin, luteolin, nobiletin, scutellarein, } \\
\text { sinensetin, tangeretin, isoorientin, orientin }\end{array}$ & & Celery, parsley, lemon grass \\
\hline $\begin{array}{l}\text { Anthocyanidins and } \\
\text { anthocyanins }\end{array}$ & $\begin{array}{l}\text { Cyanidin, delphinidin, petunidin, } \\
\text { peonidin, malvidin }\end{array}$ & $\begin{array}{l}\text { Red, blue, purple, } \\
\text { pink, mauve, violet }\end{array}$ & Red onions \\
\hline \multicolumn{4}{|c|}{ Nonflavonoid phenolic compounds } \\
\hline Phenolic acids & $\begin{array}{l}\text { Gallic acid, } p \text {-hydroxybenzoic acid, procatechuic } \\
\text { acid, vanillic acid, syringic acid, ellagic acid, } \\
\text { gallagic acid, punicalagin, gentisic acid }\end{array}$ & & $\begin{array}{l}\text { Cinnamon, clove, anise, dill, } \\
\text { fennel, caraway, parsley }\end{array}$ \\
\hline Hydroxycinammic acids & $\begin{array}{l}p \text {-coumaric, caffeic, ferulic, chlorogenic } \\
\text { acid, curcuminoids, curcumin }\end{array}$ & Yellow & Ginger, cardamom, turmeric \\
\hline Carotenoids & $\beta$-Carotene, lycopene, lutein, zeaxanthin & Yellow, orange, red & $\begin{array}{l}\text { Mustard greens, cayenne } \\
\text { pepper, chili pepper }\end{array}$ \\
\hline $\begin{array}{l}\text { Organosulfides, } \\
\text { indoles, glucosinolates/ } \\
\text { sulfur compounds }\end{array}$ & $\begin{array}{l}\text { Sulphoraphane, allyl methyl trisulfide, diallyl } \\
\text { sulfide, indol-3-carbinol, sulforaphane, sinigrin, } \\
\text { allicin, alliin, ally isothiocyanate, piperine }\end{array}$ & & $\begin{array}{l}\text { Garlic, onions, leeks, chives, } \\
\text { shallots, mustard, black pepper, } \\
\text { rutabaga, mustard green }\end{array}$ \\
\hline
\end{tabular}

ailments such as Alzheimer's disease. Spices and herbs contain antioxidants which can ameliorate conditions due to excessive free radicals in the body. An antioxidant is a compound that can donate an electron or a hydrogen atom to a free radical to neutralize it and reduce or prevent cellular damage. There are two mechanisms of action proposed for antioxidants: (1) chain-breaking step by donating an electron to the free radical, and (2) removal of ROS/reactive nitrogen species which initiates the secondary antioxidants by quenching chain-initiating catalysts including electron donation, metal ion chelation, co-antioxidants, or by gene expression regulation (Rice-Evans and Diplock, 1993). Bioactive molecules from spices and herbs act mostly as free radi- cal scavengers and block free radicals by donating a hydrogen atom. Since these antioxidant compounds possess low activation energy, the antioxidant free radicals produced are stabilized by their electrons delocalization which thus would not readily react to propagate additional free radicals. The mechanism of action can be explained by the structures of antioxidant compounds from spices and herbs (Tables 6-8, Fig. 3) in which the presence of aromatic rings and the substituent groups provide for stabilization of the structure even after donation of hydrogen atom. Most antioxidants in dietary plants are phenols, which act as chainbreaking antioxidants because their $-\mathrm{OH}$ group scavenges reactive radicals such as peroxyl radicals (ROO•). For example, car-

Table 7. Antioxidant compounds identified in rosemary and other aromatic herbs

\begin{tabular}{|c|c|c|}
\hline $\begin{array}{l}\text { Aromatic herbs in the } \\
\text { mint family Lamiaceae }\end{array}$ & Scientific name & Antioxidant compounds \\
\hline Rosemary & Rosmarinus officinalis & $\begin{array}{l}\text { Carnosal, 12-O-methylcarnosic, rosmanol, caffeic acid, rosmarinic acid, } \\
\text { caffeoyl derivatives, phenolic diterpenes (carnosic acid, carnosol, epirosmanol, } \\
\text { flavonoids, camphor, caffeic acid, ursolic acid, betulinic acid, 1,8-cineole }\end{array}$ \\
\hline Basil & Ocimum basilicum & $\begin{array}{l}\text { Eugenol, citral, citronellol, linalool, myrcene, pinene, ocimene, terpineol, linalyl } \\
\text { acetate, trans-ocimene, 1,8-cineole, camphor octanane, methyl eugenol, methyl } \\
\text { chavicol, beta-caryophylenne }\end{array}$ \\
\hline Lavender & Lavandula angustifolia & $\begin{array}{l}\text { Linalyl acetate, linalool, camphor, beta-ocimene, 1.8-cineole, borneol, } \\
\text { hotrienol, hexyl butyrate, alpha-bisabolol, caryophyllene oxide }\end{array}$ \\
\hline Marjoram & Origanum marjorana & $\begin{array}{l}\text { Beta-carotene, beta-sitosterol, caffeic-acid, carvacrol, eugenol, hydroquinone, } \\
\text { linalyl-acetate plant 3-17, myrcene, rosmarinic-acid, terpinen-4-ol }\end{array}$ \\
\hline Oregano & Origanum bulgare & $\begin{array}{l}\text { Caffeic acid, p-coumaric acid, rosmarinic acid, } \\
\text { caffeoyl derivatives, cavacrol, flavonoids }\end{array}$ \\
\hline Sage & Salvia officinalis & $\begin{array}{l}\text { Rosmanol, epirosmanol, phenolic acids (rosmarinic acid), phenolic diterpenes } \\
\text { (carnosic acid), flavonoids }\end{array}$ \\
\hline Thyme & Thymus vulgaris & $\begin{array}{l}\text { Phenolic acids (gallic acid, caffeic acid, rosmarinic acid), thymol, phenolic } \\
\text { diterpenes, flavonoids }\end{array}$ \\
\hline
\end{tabular}


Table 8. Antioxidants isolated from herbs and spice*

\begin{tabular}{|c|c|c|c|}
\hline Spice/herb & Scientific name & Antioxidant compounds & Mode of action \\
\hline Rosemary & Rosemarinus officinalis & $\begin{array}{l}\text { Carnosol, carnosic acid, rosmanol, rosmadial, diterpenes } \\
\text { (epirosmanol, isorosmanol, rosmaridipehnol, rosmariquinone, } \\
\text { rosmarinic acid }\end{array}$ & $\begin{array}{l}\text { Scavenge superoxide } \\
\text { radicals, lipid antioxidant } \\
\text { and metal chelator }\end{array}$ \\
\hline Sage & Salvia officinalis L & $\begin{array}{l}\text { Carnosol, carnosic acid, rosmanol, rosmadial, methyl and ethyl } \\
\text { esters of carnosol, rosmarinic acid }\end{array}$ & Free radical scavenger \\
\hline Oregano & Origanum vulgaris & $\begin{array}{l}\text { Rosmarinic acid, caffeic acid, protocatechuic acid, } \\
\text { 2-caffeoyloxy-3-[2-(4-hydroxybenzyl)-4,5-dihydroxy] } \\
\text { phenylpropionic acid; flavonoids-apigen, eriodictyol, } \\
\text { dihydroquercetin, dihydrokaempherol; cavacrol, tymol }\end{array}$ & Free radical scavenger \\
\hline Thyme & Thymus vulgaris $\mathrm{L}$ & $\begin{array}{l}\text { Thymol, cavacrol, p-Cumene-2,3-diol, Phenolic acids (gallic acid, } \\
\text { caffeic acid, rosmarinic acid), phenolic diterpenes, flavonoids }\end{array}$ & Free radical scavenger \\
\hline Ginger & Zingiber officinale & Gingerol. shogaol, zingerone & Free radical scavenger \\
\hline Turmeric & Curcuma domestica $\mathrm{L}$ & Curcumins, 4-hydroxycinnamoyl methane & Free radical scavenger \\
\hline Black pepper & Piper nigrum L & Kaempherol, rhamnetin, quercetin & Free radical scavenger \\
\hline Chili pepper & Capsicum frutescence $\mathrm{L}$ & Capsaicin, capsaicinol & Free radical scavenger \\
\hline Clove & Eugenia caryophyllata & $\begin{array}{l}\text { Phenolic acids (gallic acid), flavonol glucosides, phenolic } \\
\text { volatile oils (eugenol, acetyl eugenol, isoeugenol), tannins }\end{array}$ & $\begin{array}{l}\text { Free radical scavenger, } \\
\text { metal chelator }\end{array}$ \\
\hline Marjoram & Majorana hortensis & $\begin{array}{l}\text { Beta-carotene, beta-sitosterol, caffeic-acid, carvacrol, eugenol, } \\
\text { hydroquinone, linalyl-acetate plant 3-17, myrcene, } \\
\text { rosmarinic-acid, terpinen-4-ol }\end{array}$ & Free radical scavenger \\
\hline Cumin & Cumimum cymimum & $\begin{array}{l}\text { Cuminal, } \gamma \text {-terpinene, pinocarveol, linalool, } \\
\text { 1-methyl-2-(1-methylethyl)benzene, carotol }\end{array}$ & $\begin{array}{l}\text { Free radical scavenger, } \\
\text { metal chelator }\end{array}$ \\
\hline
\end{tabular}

*From various sources

Potential clinical value of curcumin

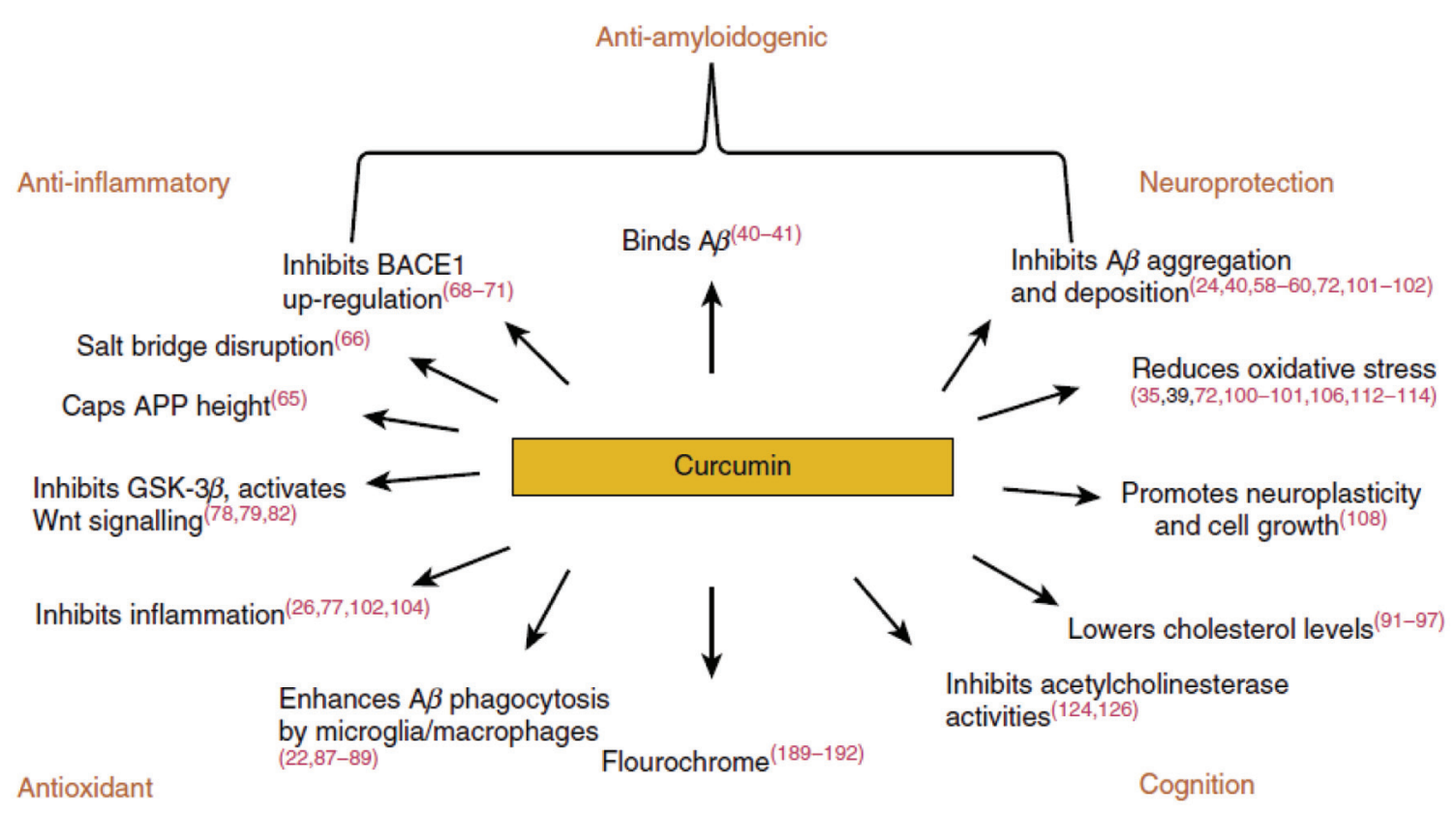

Diagnostic marker

Figure 4. Curcumin reported mechanisms of action. BACE 1, $\beta$-APP-cleaving enzyme-1: A $\beta, \beta$ amyloid; APP, amyloid precursor protein. Source: Gooze et al., 2016, Br. J. Nutr. 115, 455. Examining the potential clinical value of curcumin in the prevention and diagnosis of Alzheimer's disease. DOI: https://doi. org/10.1017/S0007114515004687. 


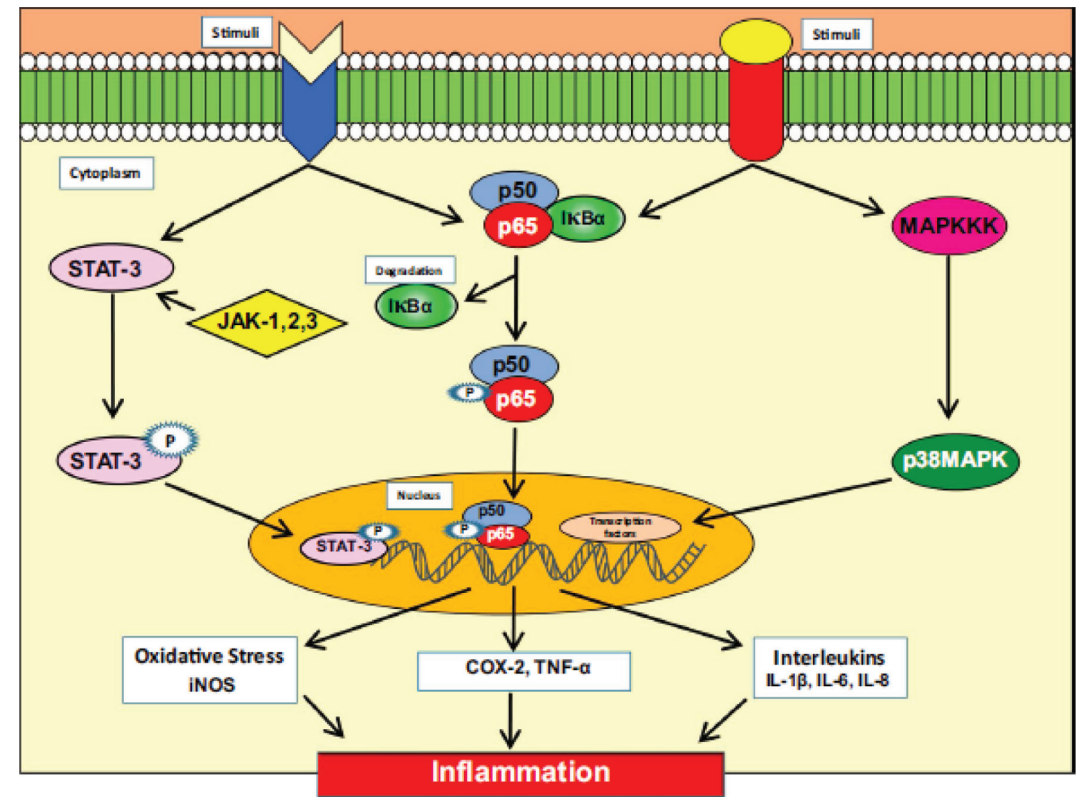

Figure 5. Molecular pathway of inflammation linked to chronic diseases. Source: Kunnumakkara et al., 2018, J. Transl. Med. 16:14. Chronic diseases, inflammation, and spices: how are they linked? BioMed Central. https://doi.org/10.1186/s12967-018-1381-2. http://creativecommons.org/publicdomain/ zero/1.0/.

nosic acid-a phenolic diterpene is rosemary's major oil-soluble antioxidant and rosmarinic acid-a caffeic acid dimer is its most powerful water-soluble antioxidant. Allicin, diallyl disulfide and diallyl trisulfide inhibit autoxidation by suppressing the hemolytic decomposition of hydroperoxides (Kim et al., 1997). Extracts of black pepper, nutmeg, rosehip, cinnamon and oregano leaf showed radical-scavenging effects and chelating capacities against $\mathrm{Fe}^{2+}$ and $\mathrm{Cu}^{2+}$ (Su et al., 2007).

The reaction mechanism of lipid oxidation involves 3 stages: initiation, propagation and termination. During the initiation stage, the lipid (RH) molecule through the action of catalysts breaks down to produce free radicals which can react with lipids, proteins or DNA causing cellular damage. More free radicals are formed during the propagation phase resulting in rapid oxidation. These free radicals react with oxygen to produce more free radicals to quickly oxidize lipid or other molecules. To prevent, minimize or slow down the rate of oxidation, oxygen and metal catalysts must be removed, or sequestered to render them unreactive. The

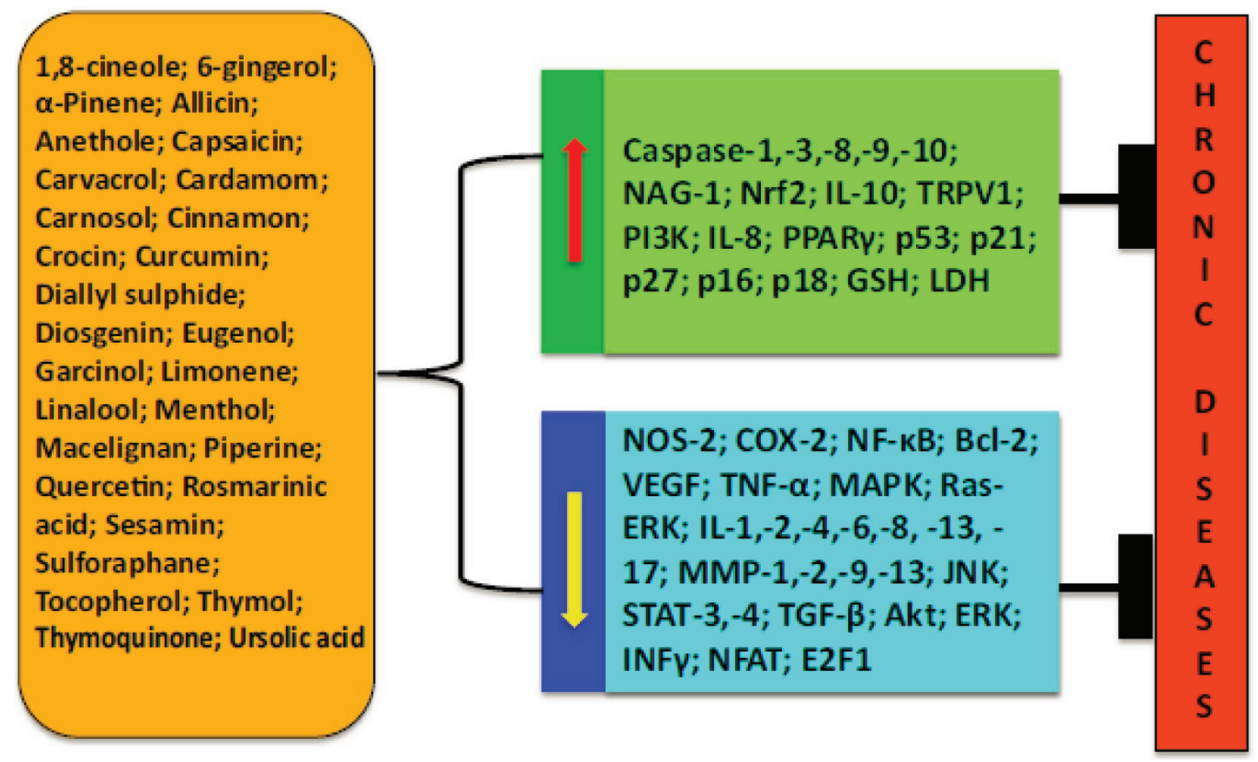

Figure 6. Different bioactive components of spices and their molecular mechanisms against chronic diseases. Source: Kunnumakkara, et al., 2018, J. Transl. Med. 16:14. Chronic diseases, inflammation, and spices: how are they linked? https://doi.org/10.1186/s12967-018-1381-2. http://creativecommons.org/ publicdomain/zero/1.0/. 


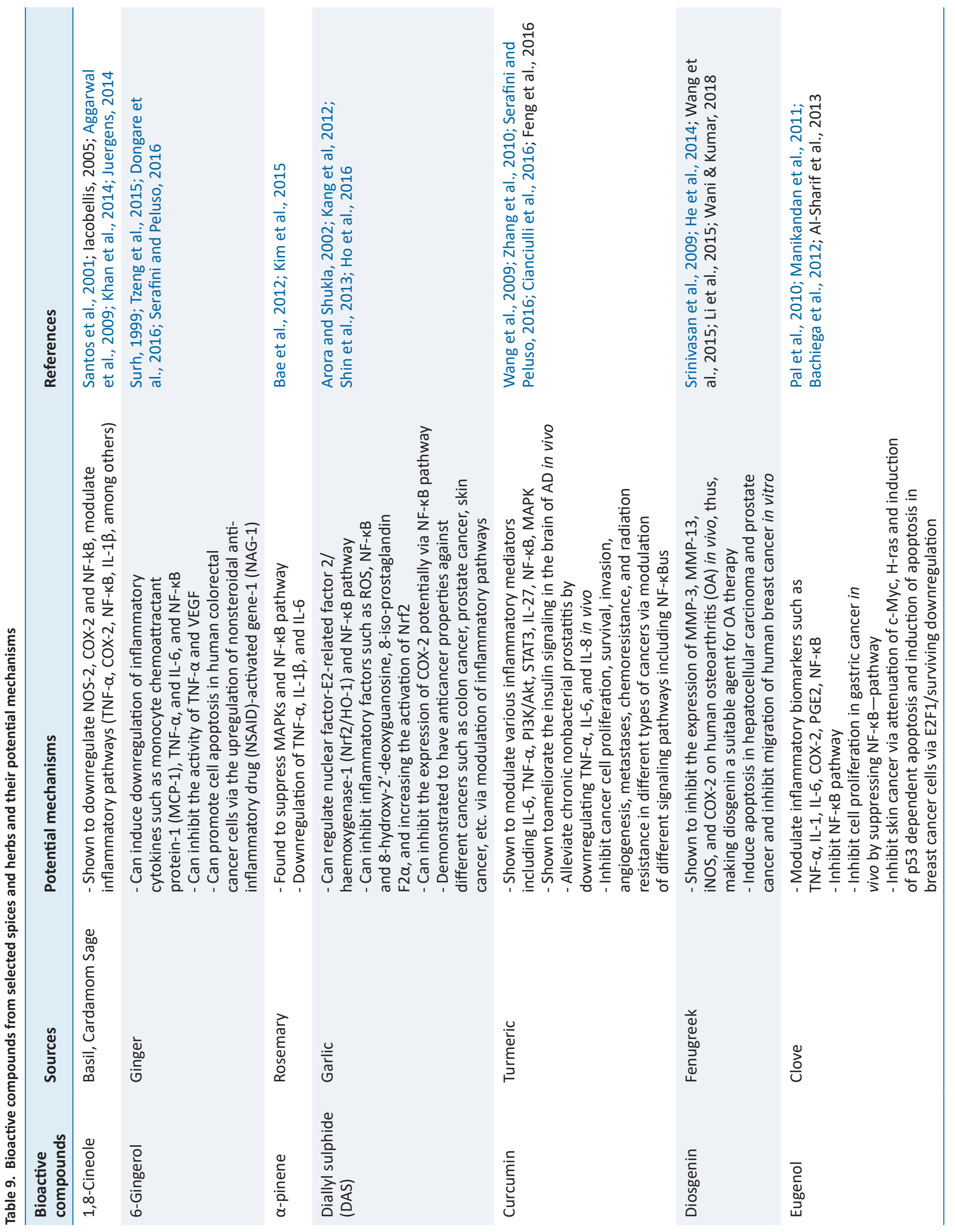




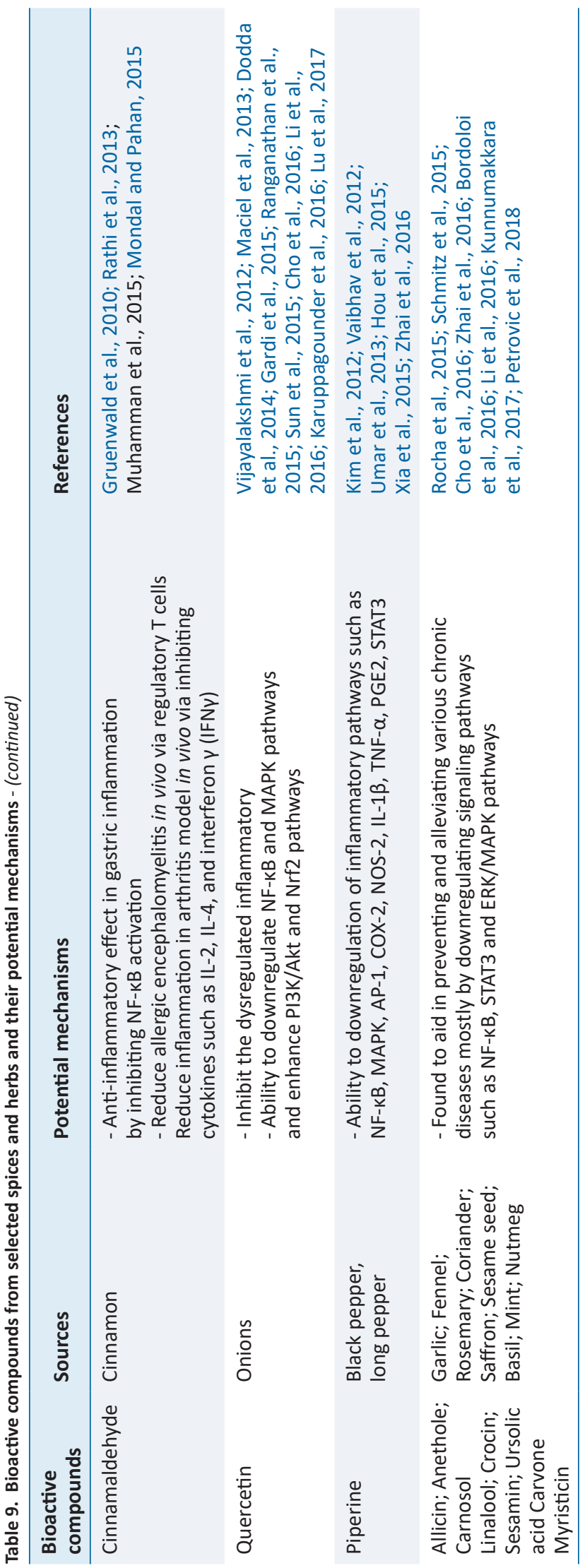

antioxidants from spices and herbs can minimize or stop oxidation through their free radical scavenging property at various stages of oxidation: (1) Initiation stage - oxygen scavengers and/or chelating agents; (2) Propagation stage - oxygen and/or free radical scavengers; and (3) Termination stage-free radical scavengers. Through these, the free radicals are neutralized and thus reducing their capacity to damage cellular tissues.

The effects of excessive free radicals in the body is termed as oxidative stress and in the absence of antioxidants to neutralize them are responsible for: (1) Inflammatory diseases — arthritis, vasculitis, glomerulonephritis, lupus erythematous, adult respiratory diseases syndrome; (2) Ischemic diseases - heart diseases, stroke, intestinal ischema; (3) neurological disorder-Alzheimer's disease, Parkinson's disease, muscular dystrophy and many other diseases (Lobo, 2010; Shahidi and Ambigaipalan, 2015).

\section{Anti-inflammatory effects of spices and herbs}

When the human body is exposed to environmental stressors and pathogens, the response is inflammation. There are 2 stages that occur in response to these stimuli (Aggarwal et al., 2009): (1) acute inflammation that is initiated by the immune cells which occurs in a short time; but if the inflammation persists, (2) chronic inflammation is initiated which brings about chronic diseases such as arthritis, cancer, cardiovascular diseases, diabetes, and neurological diseases.

Figure 5 shows the molecular pathway of inflammation linked to chronic diseases (Kunnumakkara et al., 2018).

Based on this diagram, NF- $\mathrm{BB}$ and STAT3, inflammatory enzymes such as cyclooxygenase-2 (COX-2), matrix metalloproteinase- 9 (MMP-9), and inflammatory cytokines such as tumor necrosis factor alpha (TNF- $\alpha$ ), interleukins (IL) such as IL-1, -6, -8, and chemokines are the main molecular mediators of the immune responses to infection, injury or environmental stressors (Kunnumakkara et al., 2018). What occurs next is the translocation of subunits p50 and p65 into the nucleus which bind to the promoters regions of various genes and activate more than 400 genes that are involved in inflammation and other chronic diseases (Yadav et al., 2010). When NF- $\kappa$ B is activated, it is known to initiate cancel cell proliferation, survival, invasion, angiogenesis, metastasis, chemoresistance, and radiation resistance and it also regulates the expression of inflammatory mediators such as COX-2, inducible nitric oxide synthase (iNOS), TNF- $\alpha$, and interleukins (Kawabata et al., 2010). Overexpression of the cytokine, TNF- $\alpha$, the most potent pro-inflammatory cytokine so far discovered, can lead to various chronic diseases, including cancer, via the activation of NF- $\kappa B$ (Kunnumakkara et al., 2018). There are several potential strategies that can be used for the prevention and management of chronic diseases: (1) Employ blockers of TNF- $\alpha$, (2) Upregulation of COX-2, iNOS, and aberrant expression of TNF- $\alpha$ and IL-1, IL-6 and IL-8 have been reported to play important roles in oxidative stress that leads to inflammation (Aggarwal 2009; Reuter et al., 2010; Sung et al., 2012; Pandurangan et al., 2015), and (3) Employ the mitogenactivated protein kinase pathway (MPK) as a potential molecular target for the treatment of chronic inflammatory diseases (Liang et al., 2016).

Spices and herbs contain bioactives that can interact with multiple targets and alter dysregulated inflammatory pathways and mediators associated with chronic diseases (Kunnumakkara, et al., 2018, Figure 6). A summary of these bioactives and their potential mechanisms for mitigating chronic diseases are summarized in Table 9. 


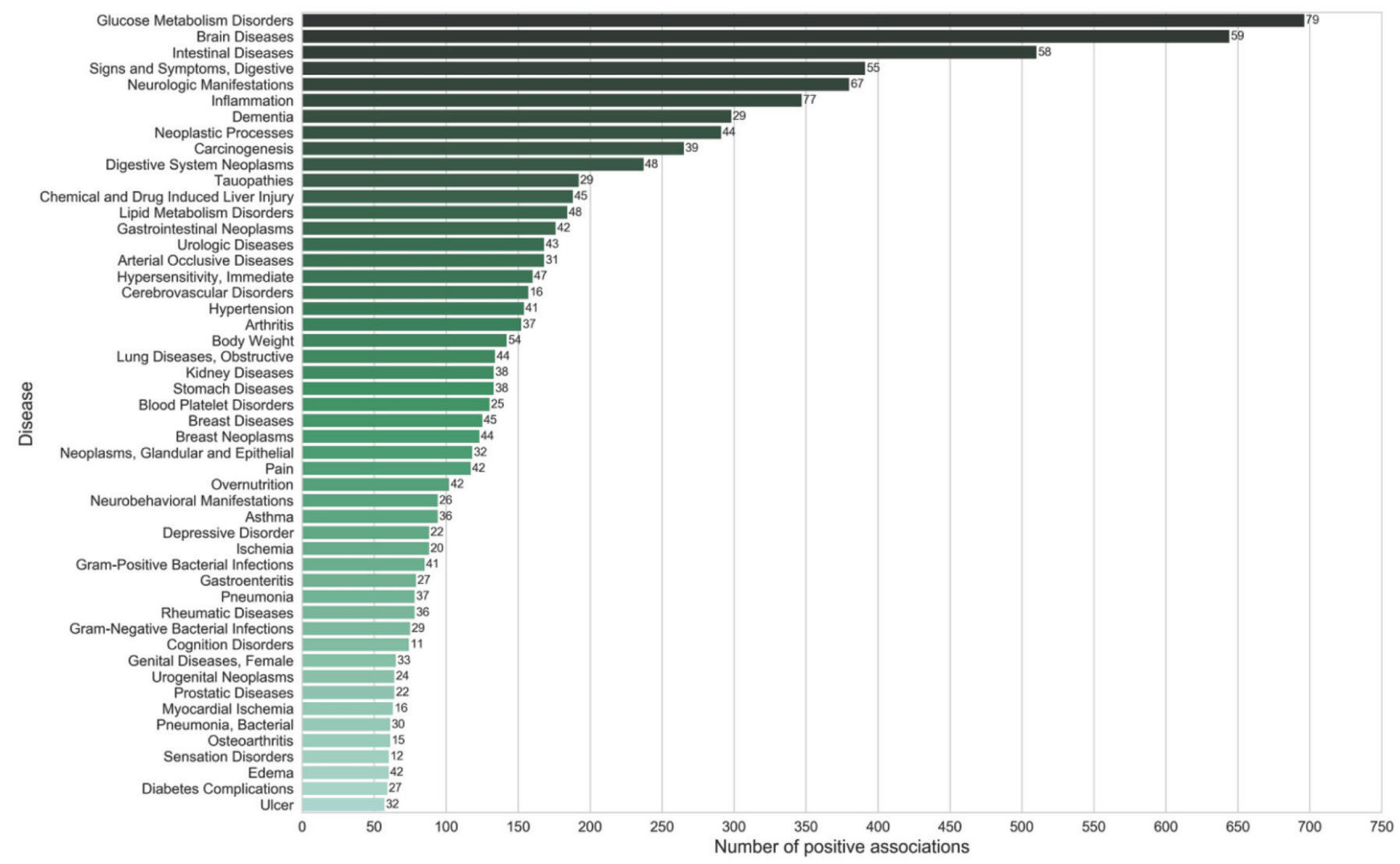

Figure 7. Top diseases (Third level of MeSH hierarchy) ranked according to their total number of positive associations. Numbers shown against the bars indicate the 'number of spices' involved in the associations. Source: Rakhi et al., 2018, PLoS ONE 13(5): e0198030. Data-driven analysis of biomedical literature suggests broad-spectrum benefits of culinary herbs and spices. (MeSH-Medical Subject Headings is a controlled vocabulary of biomedical terms curated and developed by National Library of Medicine. It organizes terms hierarchically from general to more specific.). www.PLOS.org. https://doi. org/10.1371/journal.pone.0198030.

\section{Anticarcinogenic and chemopreventative activities associ- ated with spices}

DNA damage has been associated with aging and cancer. Pathways associated in the development of cancer includes oxidative DNA damage brought about by redox activity of endogenous and exogenous species such as caused by active oxygen species (ROS). Jebalan et al. (2015) reported 11 aqueous and non-aqueous extracts from anise (Pimpinella anisum), coriander (Coriandrum sativum var. vulgare), cumin (Cuminum cyminum), dill (Anethum graveolens), fennel (Foeniculum vulgare var. vulgare), caraway (Carum carvi), celery (Apium graveolens) parsley (Petroselinum crispum), carrot seeds (Daucus carota), angelica (Angelica archangelica), and ajowan (Carum copticum) all from the Apiaceae family. Jebalan et al. (2015) found that aqueous $(5 \mathrm{mg} / \mathrm{ml})$ and non-aqueous extracts $(6 \mathrm{mg} / \mathrm{ml})$ substantially inhibited $(83-98 \%)$ formation of DNA adducts in the microsomal reaction but only aqueous extracts showed the inhibitory activity (83-96\%) in non-microsomal reaction. Adduct inhibition was also observed at 5-fold lower concentrations of aqueous extracts of cumin (60\%) and caraway (90\%), and 10 -fold lower concentrations of carrot seeds $(76 \%)$ and ajowan $(90 \%)$ and these results suggests the presence of two groups of phytochemicals - polar compounds that have free radical-scavenging activity, and lipophilic compounds that selectively inhibit P450 activity associated with estrogen metabolism (Jebalan et al., 2015). These are significant findings which demonstrate that these
Apiaceae species may be potentially protective against estrogenmediated breast cancer.

In another study on the in vitro evaluation on prostate cells, Lackova et al. (2017) showed that the extracts from black pepper and caraway seed gave the strongest inhibitory effect on prostatic cells using the Cell-Line Proliferative Activity Testing (MTT Assay). This is used to evaluate the cells' metabolic activity and provide the cytotoxicity of the tested compounds. The activity of the black pepper extract was postulated to be due to 3,4-dihydroxybenzaldehyde and naringenin chalcone and from caraway seeds, neochlorogenic acid and apigenin. Lackova et al. (2017) identified naringenin chalcone to be the most potent growth inhibitor of prostate cell.

Vanilla is one of the most important spices and flavorings. Vanillin which is responsible for the desirable aroma and flavor in vanilla extract has been shown to suppress metastasis in a mouse model (Jantaree et al., 2017) using the Transwell invasion assay but the homodimer of vanillin (divanillin, also a vanilla extract compound) exhibited a potency higher than vanillin and apocynin which was attributed to inhibiting phosphorylation of FAK and Akt and divanillin's stronger binding to the Y397 pocket of the FAK FERM domain based on molecular docking studies.

A review on spices for prevention and treatment of cancers by Zheng et al. (2016) evaluated more than 250 scientific papers on the subject. They concluded that numerous studies have documented the antioxidant, anti-inflammatory and immunomodulatory effects 


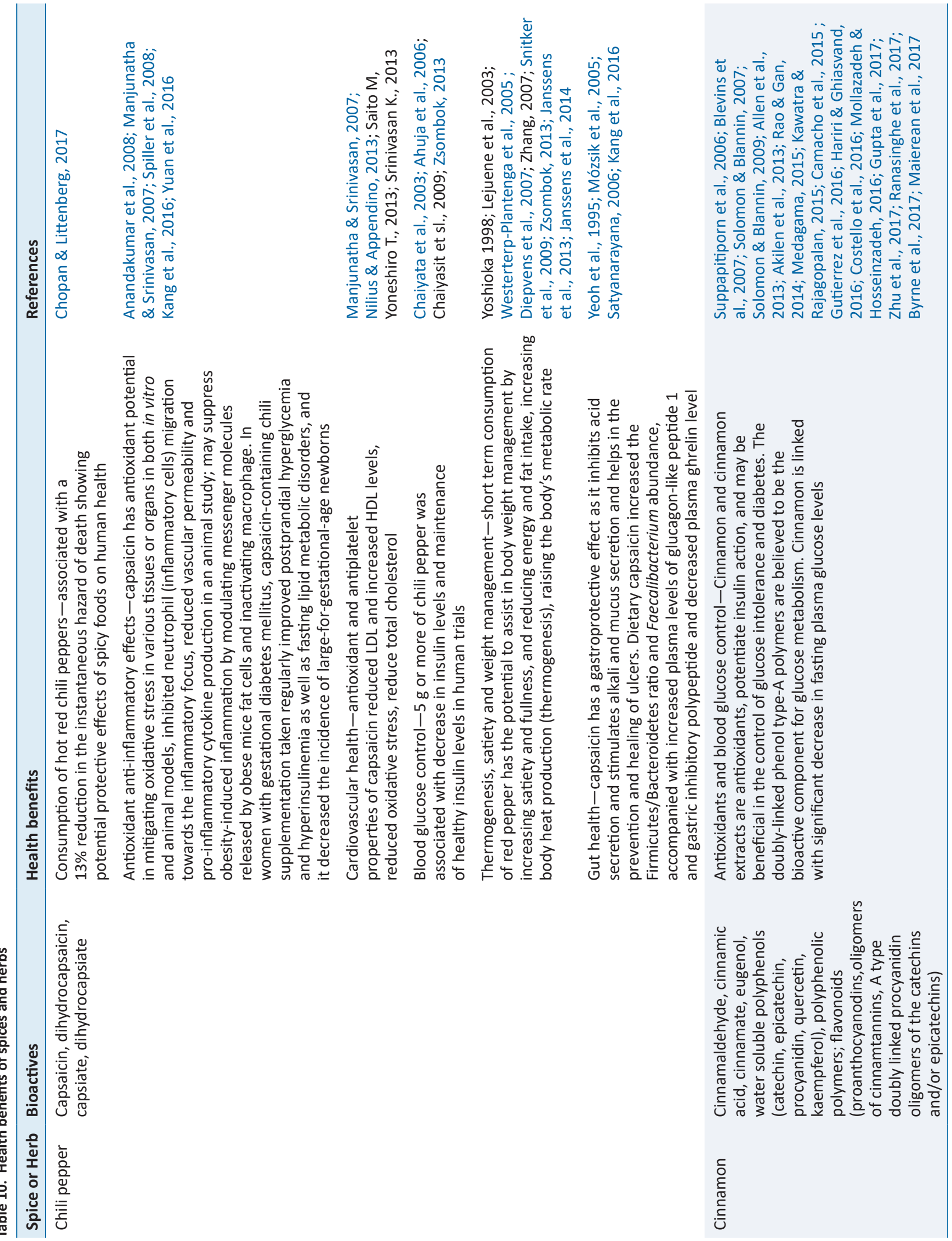




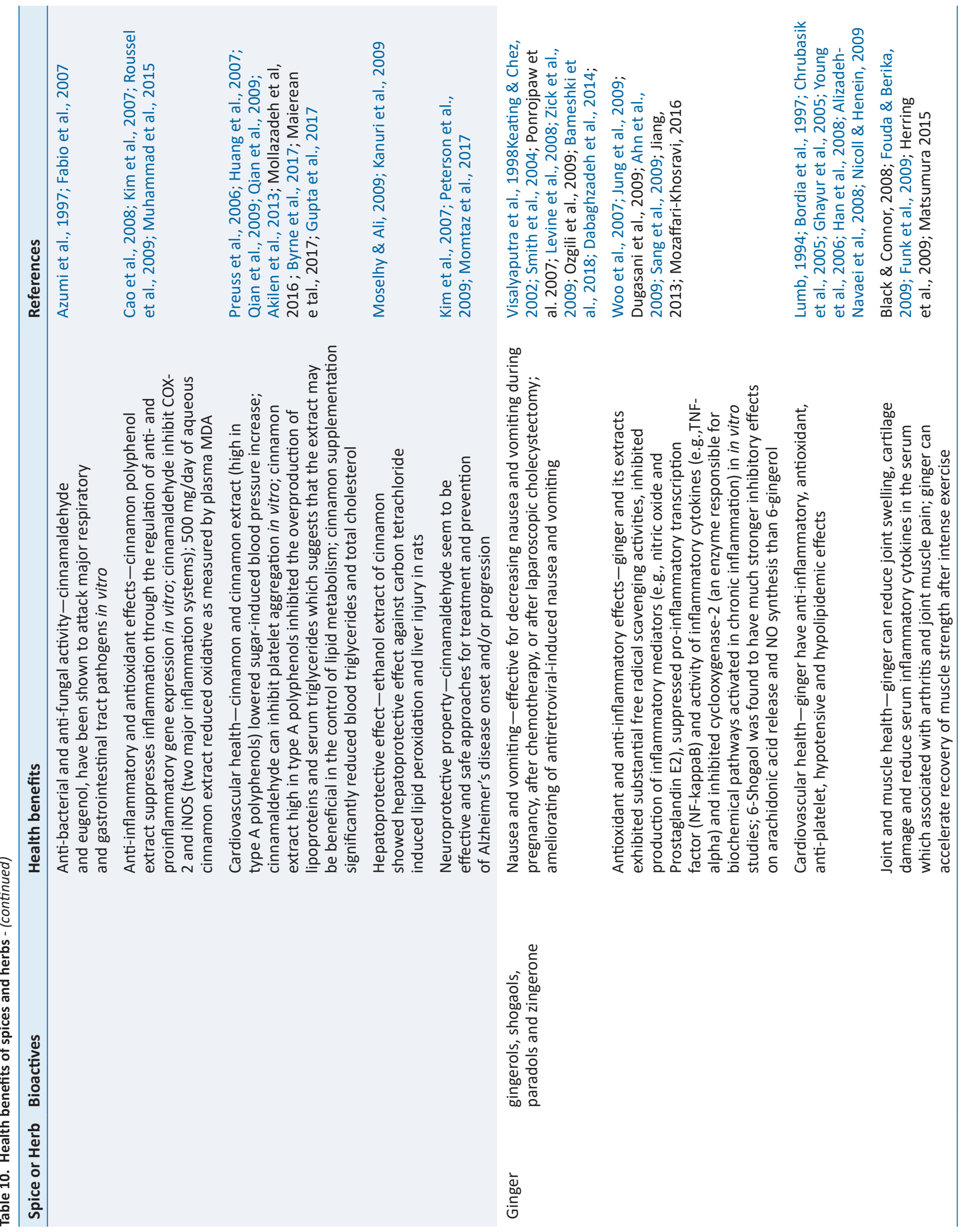




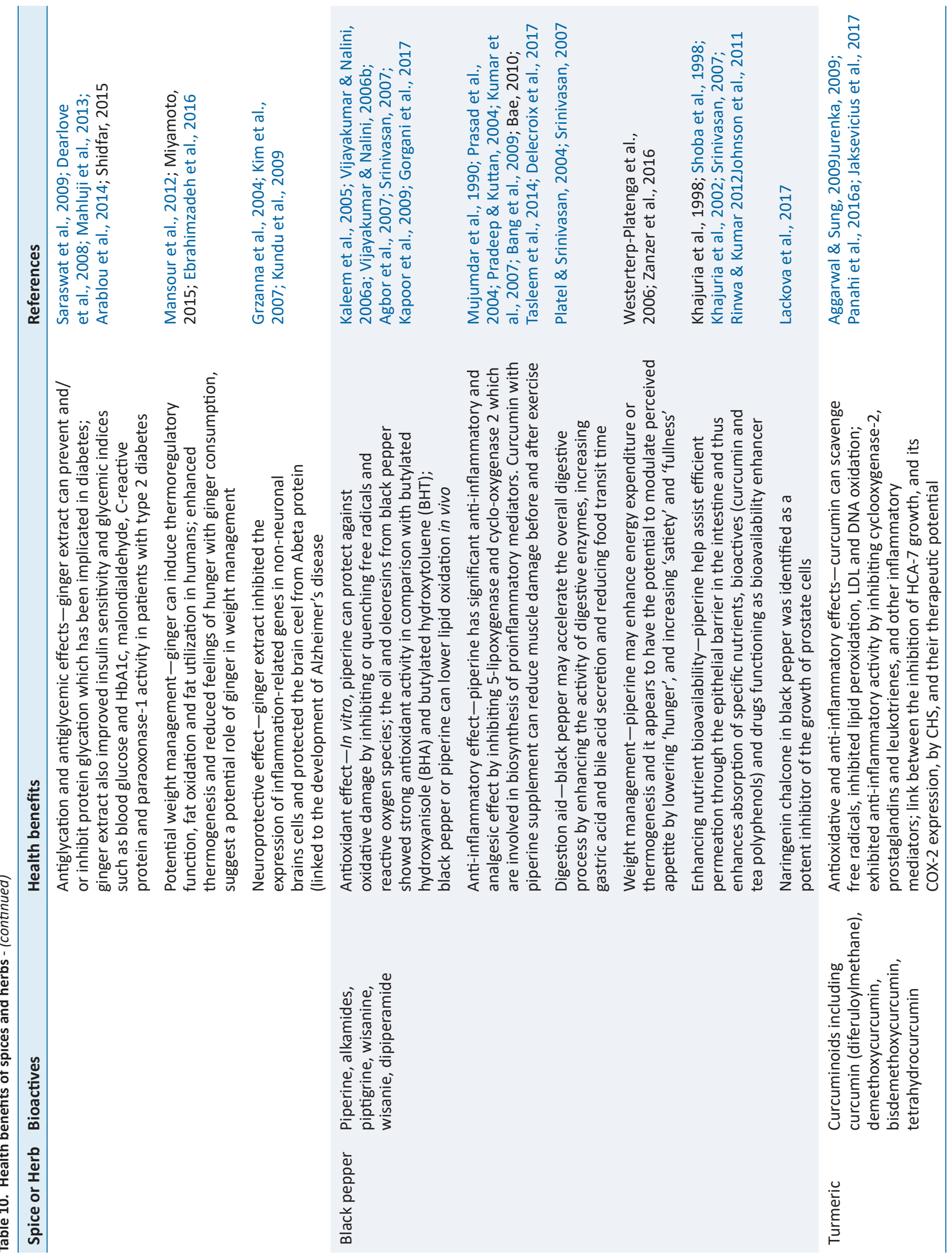




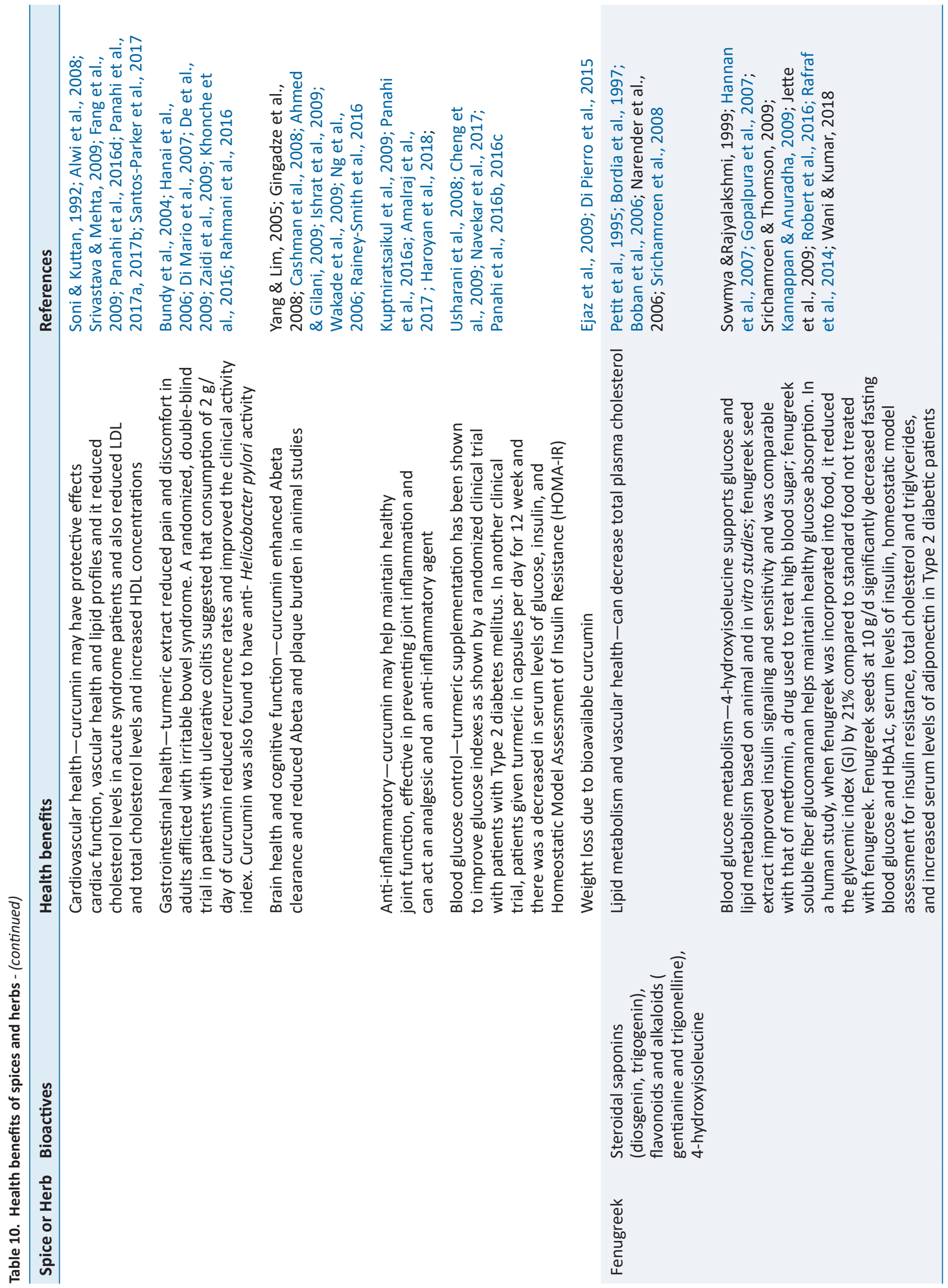




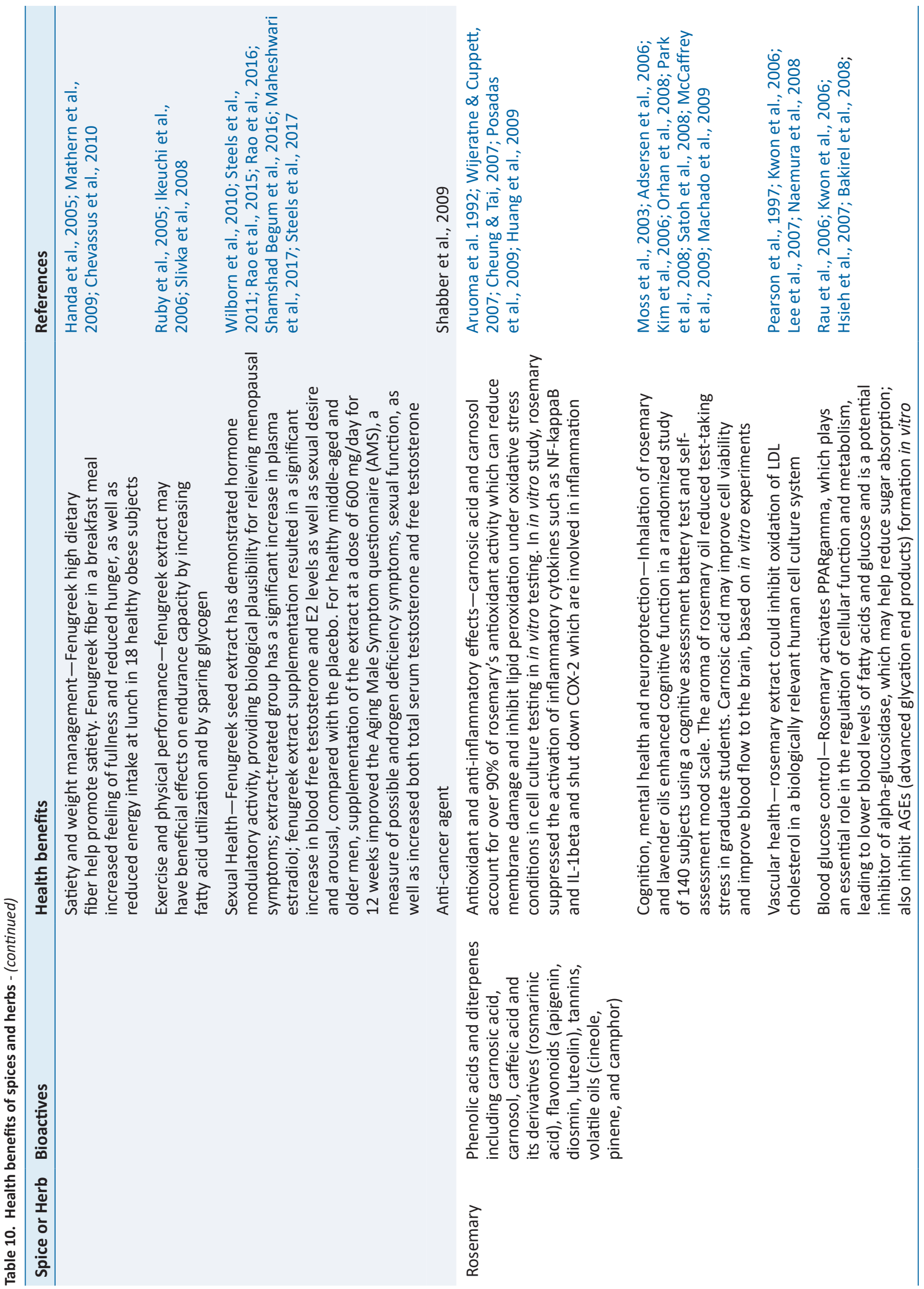




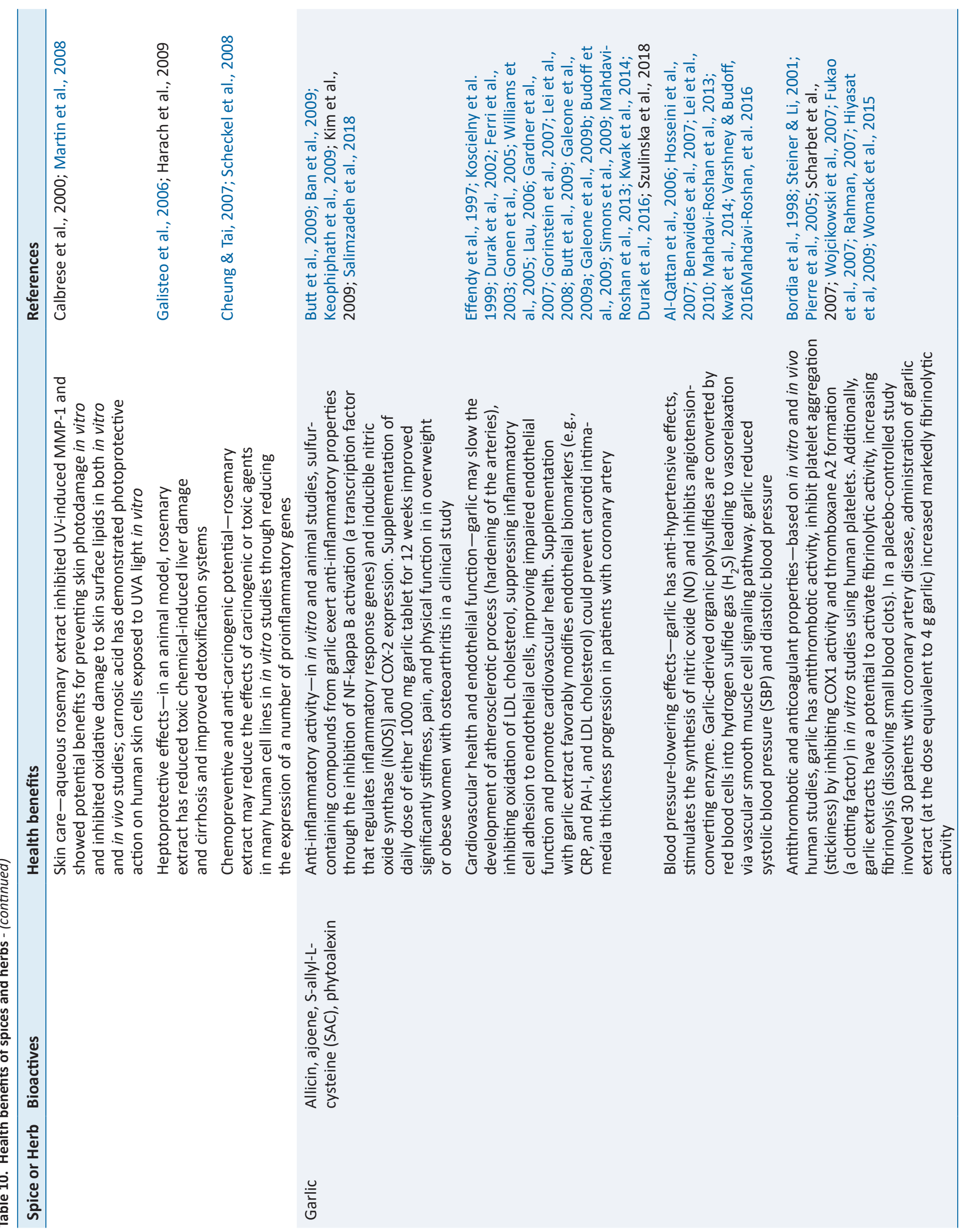




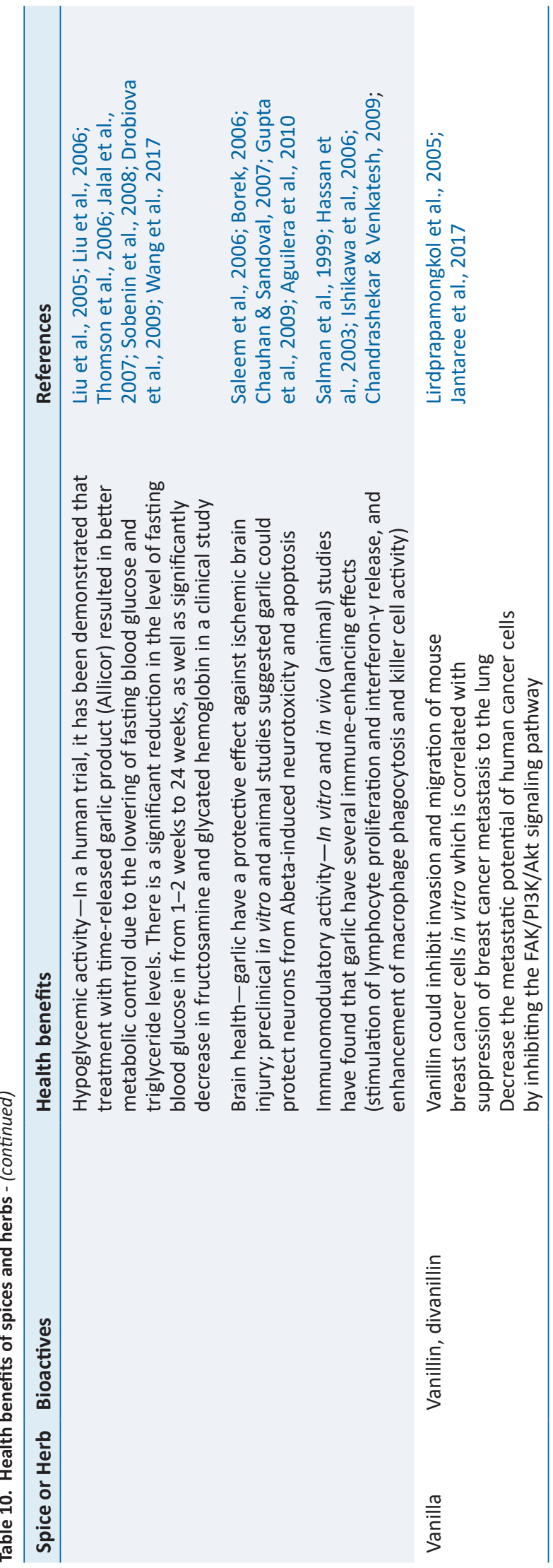

of spices might be related to prevention and treatment of several cancers and that several spices are potential sources of bioactive compounds for these effects: Curcuma longa (tumeric), Nigella sativa (black cumin), Zingiber officinale (ginger), Allium sativum (garlic), Crocus sativus (saffron), Piper nigrum (black pepper) and Capsicum annum (chili pepper). These spices contain several important bioactive compounds, such as curcumin, thymoquinone, piperine and capsaicin the mechanisms of action include inducing apoptosis, inhibiting proliferation, migration and invasion of tumors, and sensitizing tumors to radiotherapy and chemotherapy.

\section{Blood glucose control of spices and herbs}

Bioactives from chili pepper, cinnamon, ginger, turmeric, fenugreek, rosemary, and garlic maybe beneficial in the control of glucose intolerance and diabetes (Srinivasan, 2005; Chase and McQueen, 2007; Magistrelli and Chezem, 2012; Bayan et al., 2014; Upsani et.al., 2014; Heshmati and Namazi, 2015; Rashmi and Shilpy, 2016; Bi and Lim, 2017; Yasnin et al., 2017; Ge et al., 2017; Ranasinghe et al., 2017; Byrne et al., 2017 ). Figure 7 shows that associated with spices, it was found that diabetes mellitus, inflammation and carcinogenesis have the highest number positive associations and that the spices have a preventive role in various cancers (Rakhi et al., 2018). Chili pepper was associated with a decrease in insulin levels and healthy insulin in human trials while the doubly-linked phenol type-A polymers in cinnamon is the bioactive responsible for the control of glucose intolerance and potentiates insulin action. Ginger on the other hand can prevent and/or inhibit protein glycation which has been implicated in diabetes. Turmeric has been shown to improve glucose indices and decrease glucose in serum. An extract of fenugreek seed improved insulin signaling and sensitivity and was comparable with metroformin, a drug used to treat high blood sugar. The soluble fiber in fenugreek helps maintain healthy glucose absorption. Rosemary activates PPARgamma leading to lower levels of glucose and inhibitor of $\alpha$-glucosidase which may help reduce sugar absorption. Garlic powder tablets (Allicor) lowered fasting blood glucose.

There are other benefits of bioactives from spices and herbs such as enhancing nutrient bioavailability (piperine), weight management and satiety (chili pepper, ginger, fenugreek, piperine), gut health (chili pepper, turmeric), anti-bacterial and anti-fungal (eugenol and cinnamaldehyde from cinnamon), hepatoprotective effect against $\mathrm{CCl}_{4}$ (ethanol extract of cinnamon), neuroprotective (cinnamaldehyde from cinnamon), reduce nausea and vomiting during pregnancy or after chemotherapy (ginger), joint and muscle health (ginger), digestion aid (black pepper), lipid metabolism and vascular health (fenugreek, rosemary), chemopreventive and anticarcinogenic (rosemary), antithrombotic and anticoagulant (garlic), and immunomodulatory activity (garlic). Prevalence of cardiovascular disease (CVD) as correlated to diets in which spices play an important role was summarized by Tsui et al. (2018). Based on this review incidence of CVD increases when spices are not used in preparation of food as follows (1) Western diet (spice-free with salt and sugar): $11-15 \%$, (2) Arabic diet (saffron, peppers, allspice, turmeric, garlic, cumin, cinnamon, parsley and coriander): $7-12 \%$, (3) Indian diet (cardamom, clove, cassis, peppers, cumin coriander, nutmeg, mustard seed, fenugreek, turmeric, saffron and garlic): $7-11 \%$ (4) Chinese diet (Cardamom, cinnamon, cumin, cloves, peppers, nutmeg, peppercorns, fennel, star anise, garlic, ginger and chili peppers): 5\%, and (5) Mediterranean diet (Anise, basil, bay leaf, cardamom, cinnamon chervil, chilis, chives, cloves, cumin, coriander, dill, fennel, fenugreek, garlic, mace, marjoram, 
mint, nutmeg, oregano, peppers, rosemary, saffron, sage, savory, sumac, tarragon and thyme): $1.5-3.2 \%$ (Tsui et al., 2018). Table 10 provides the health benefits of spices and herbs in greater detail based on various studies including the referenced scientific publications.

\section{Summary}

For millennia, spices and herbs have been used to flavor food but are also sought after for their medicinal power. In fact, as early as the $1^{\text {st }}$ through the $4^{\text {th }}$ centuries, Arabian developed techniques to distill essential oils from aromatic plants and around the $9^{\text {th }}$ century, Arab physicians used spices and herbs to formulate syrup and flavoring extracts (Rosengarten, 1969) for homeopathic remedies. Today, there is a large volume of evidence that spices and herbs can help alleviate conditions linked with specific diseases as well as prevent or reduce risks associated with degenerative diseases such as cardiovascular diseases, diabetes, obesity and cancer. This is also supported by findings on meta-analysis of more than 1.5 million healthy adults that following a Mediterranean diet which included spices and herbs was associated with a reduced risk of cardiovascular mortality as well as overall mortality (Mayo Clinic, 2019). Scientific studies provided proof that spices and herbs from black pepper to vanilla contain phytochemicals that show strong antioxidant and anti-inflammatory activities both in vitro and in vivo and in clinical studies. Spices and herbs have shown therapeutic and protective potential against chronic disorders due to their anti-inflammatory, antiproliferative and pharmacological activities. There are still potential areas for future research that include concentration effects on treatment and acceptability, differences in reaction of humans to different phytochemicals as well as employing nutrigenomics to understand how the compounds in the diet (e.g., from spices and herbs) affect health by altering the expression of genes and the structure of an individual's gene at a molecular level.

\section{References}

Abrams, S.A., Griffin, I.J., Hawthorne, K.M., Liang, L., Gunn, S.K., Darlington, G., and Ellis, K.J. (2005). A combination of prebiotic short- and long-chain inulin-type fructans enhances calcium absorption and bone mineralization in young adolescents. Am. J. Clin. Nutr. 82(2): 471-476.

Adsersen, A., Gauguin, B., and Gudiksen, L. (2006). Screening of plants used in Danish folk medicine to treat memory dysfunction for acetylcholinesterase inhibitory activity. J. Ethnopharmacol. 104(3): 418-422.

Agbor, G.A., Vinson, J.A., Oben, J.E., and Ngogang, J.Y. (2007). In vitro antioxidant activity of three Piper species. J. Herb Pharmacother. 7(2): 49-64.

Aggarwal, B.B. (2009). Inflammation, a silent killer in cancer is not so silent! Curr. Opin Pharmacol. 9(4): 347-50.

Aggarwal, B., and Kunnumakkara, A.B. (2009). Molecular Targets and Therapeutic Uses of Spices: Modern Uses for Ancient Medicine. 1st ed. World Scientific Publishing Company, New Jersey, pp. 1-430.

Aggarwal, B.B., and Sung, B. (2009). Pharmacological basis for the role of curcumin in chronic diseases: an age-old spice with modern targets. Trends Pharmacol. Sci. 30(2): 85-94.

Aggarwal, B.B., Van Kuiken, M.E., Iyer, L.H., Harikumar, K.B., and Sung, B. (2009). Molecular targets of nutraceuticals derived from dietary spices: potential role in suppression of inflammation and tumorigenesis. Exp. Biol. Med. (Maywood). 234(8): 825-849.

Aguilera, P., Chánez-Cárdenas, M.E., and Ortiz-Plata, A. (2010). Aged garlic extract delays the appearance of infarct area in a cerebral ischemia model, an effect likely conditioned by the cellular antioxidant systems. Phytomedicine. 17(3-4): 241-247.

Ahmed, T., and Gilani, A.H. (2009). Inhibitory effect of curcuminoids on acetylcholinesterase activity and attenuation of scopolamine-induced amnesia may explain medicinal use of turmeric in Alzheimer's disease. Pharmacol. Biochem. Behav. 91(4): 554-559.

Ahn, S.I., Lee, J.K., and Young, H.S. (2009). Inhibition of homodimerization of toll-like receptor 4 by 6 -shogaol. Mol. Cells. 27(2): 211-215.

Ahuja, K.D., Robertson, I.K., Geraghty, D.P., and Ball, M.J. (2006). Effects of chili consumption on postprandial glucose, insulin, and energy metabolism. Am. J. Clin. Nutr. 84(1): 63-69.

Akilen, R., Pimlott, Z., Tsiami, A., and Robinson, N. (2013). Effect of shortterm administration of cinnamon on blood pressure in patients with prediabetes and type 2 diabetes. Nutrition. 29(10): 1192-6.

Allen, R.W., Schwartzman, E., Baker, W.L., Coleman, C.I., and Phung, O.J. (2013). Cinnamon use in type 2 diabetes: an updated systematic review and meta-analysis. Ann. Fam. Med. 1(5): 452-459.

Alizadeh-Navaei, R., Roozbeh, F., and Saravi, M. (2008). Investigation of the effect of ginger on the lipid levels. A double blind controlled clinical trial. Saudi Med. J. 29(9): 1280-1284.

Al-Qattan, K.K., Thomson, M., and Al-Mutawa'a, S. (2006). Nitric oxide mediates the blood-pressure lowering effect of garlic in the rat twokidney, one-clip model of hypertension. J. Nutr. 136(3 Suppl): 774S776 S.

Al-Sharif, I., Remmal, A., and Aboussekhra, A. (2013). Eugenol triggers apoptosis in breast cancer cells through E2F1/surviving down-regulation. BMC Cancer 13: 600.

Alwi, I., Santoso, T., and Suyono, S. (2008). The effect of curcumin on lipid level in patients with acute coronary syndrome. Acta Med. Indones. 40(4): 201-210.

Amalraj, A., Varma, K., and Jacob, J. (2017). A novel highly bioavailable curcumin formulation improves symptoms and diagnostic indicators in rheumatoid arthritis patients: A randomized, double-blind, placebocontrolled, two-dose, three-arm, and parallel-group study. J. Med. Food. 20(10): 1022-1030.

Anandakumar, P., Kamaraj, S., and Jagan, S. (2008). Capsaicin modulates pulmonary antioxidant defense system during benzo(a)pyreneinduced lung cancer in Swiss albino mice. Phytother. Res. 22(4): 529-533.

Anderson, J.J., Anthony, M.S., Cline, J.M., Washburn, S.A., and Garner, S.C. (1999). Health potential of soy isoflavones for menopausal women. Public Health Nutr. 2: 489-504.

Arablou, T., Aryaeian, N., Valizadeh, M., Sharifi, F., Hosseini, A., and Djalali, M. (2014). The effect of ginger consumption on glycemic status, lipid profile and some inflammatory markers in patients with type 2 diabetes mellitus. Int. J. Food Sci. Nutr. 65(4): 515-520.

Arora, A., and Shukla, Y. (2002). Induction of apoptosis by diallyl sulfide in DMBS-induced mouse skin tumors. Nutrition and Cancer. 44(1): $89-94$.

Aruoma, O.I., Halliwell, B., and Aeschbach, R. (1992). Antioxidant and prooxidant properties of active rosemary constituents: carnosol and carnosic acid. Xenobiotica. 22(2): 257-268.

Aryaeian, N., Sedehi, S.K., and Arablou, T. (2017). Polyphenols and their effects on diabetes management: A review. Med. J. Islam Repub. Iran. 31: 134 .

Azumi, S., Tanimura, A., and Tanamoto, K. (1997). A novel inhibitor of bacterial endotoxin derived from cinnamon bark. Biochem. Biophys. Res. Commun. 7(234): 506-510.

Bachiega, T.F., de Sousa, J.P., Bastos, J.K., and Sforcin, J.M. (2012). Clove and eugenol in noncytotoxic concentrations exert immunomodulatory/anti-inflammatory action on cytokine production by murine macrophages. J. Pharm. Pharmacol. 64(4): 610-616.

Bae, G.S., Kim, M.S., Jung, W.S., Seo, S.W., Yun, S.W., Kim, S.G., Park, R.K., Kim, E.C., Song, H.J., and Park, S.J. (2010). Inhibition of lipopolysaccharide-induced inflammatory responses by piperine. Eur. J. Pharmacol. 642(1-3): 154-1562.

Bae, G.S., Park, K.C., Choi, S.B., Jo, I.J., Choi, M.O., Hong, S.H., Song, K., Song, H.J., and Park, S.J. (2012). Protective effects of alpha-pinene in mice with cerulein-induced acute pancreatitis. Life Sci. 91(17-18): 866-871.

Bakirel, T., Bakirel, U., Keleş, O.U., Ulgen, S.G., and Yardibi, H. (2008). In 
vivo assessment of antidiabetic and antioxidant activities of rosemary (Rosmarinus officinalis) in alloxan-diabetic rabbits. J. Ethnopharmacol. 116(1): 64-73.

Bameshki, A., Namaiee, M.H., Jangjoo, A., Dadgarmohhaddam, M., Ghalibaf, M.H.E., Ghorbanzadeh, A., and Sheybani, S. (2018). Effect of oral ginger on prevention of nausea and vomiting after laparoscopic cholecystectomy: a double-blind, randomized, placebo-controlled trial. Electron Physician. 10(2): 6354-6362.

Ban, J.O., Oh, J.H., Kim, T.M., Kim, D.J., Jeong, H., Han, S.B., and Hong, J.T (2009). Anti-inflammatory and arthritic effects of thiacremonone, a novel sulfur compound isolated from garlic via inhibition of NF-kappaB. Arthritis Res. Ther. 11(5): R145.

Bang, J.S., Oh, D.H., Choi, H.M., Sur, B., Lim, S., Kim, J.Y., Yang, H., Yoo, M.C., Hahm, D., and Kim, S.K. (2009). Anti-inflammatory and antiarthritic effects of piperine in human interleukin $1 \beta$-stimulated fibroblast-like synoviocytes and in rat arthritis models. Arthritis Res. Ther. 11(2): R49.

Bayan, L., Koulivand, P.H., and Gorji, A. (2014). Garlic: a review of potential therapeutic effects. Avicenna J. Phytomed. 4(1): 1-14.

Benavides, G., Squadrito, G.L., Mills, R.W., Patel, H.D., Isbell, T.S., Patel, R.P., Darley-Usmar, V.M., Doeller, J.E., and Kraus, D.W. (2007). Hydrogen sulfide mediates the vasoactivity of garlic. Proc. Natl. Acad. Sci. USA. 104(46): 17977-17982.

Bindels, L.B., Delzenne, N.M., Cani, P.D., and Walter, J. (2015a). Towards a more comprehensive concept for prebiotics. Nat. Rev. Gastroenterol. Hepatol. 12(5): 303-310.

Bindels, L.B., Neyrinck, A.M., Salazar, N., Taminiau, B., Druart, C., and Muccioli, G.G. (2015b). Non digestible oligosaccharides modulate the gut microbiota to control the development of leukemia and associated cachexia in mice. PLoS ONE 10(6): e0131009.

Black, C.D., and O'Connor, P.J. (2008). Acute effects of dietary ginger on quadriceps muscle pain during moderate-intensity cycling exercise. Int. J. Sport. Nutr. Exerc. Metab. 18(6): 653-664.

Blevins, S.M., Leyva, M.J., Brown, J., Wright, J., Scofield, R.H., and Aston, C.E. (2007). Effect of cinnamon on glucose and lipid levels in noninsulin-dependent type 2 diabetes. Diabetes Care. 30(9): 2236-2237.

Block, E., Putman, D., and Zhao, S.H. (1992). Allium chemistry: GC-MS analysis of thiosulfinates and related compounds from onion, leek, scallion, shallot, shive and chinese chive. J. Agric. Food Chem. 40(12): 2431-2438.

Block, E., Naganathan, S., Putman, D., and Zhao, S.H. (1993a). Organosulfur chemistry of garlic and onion: Recent results. Pure Appl. Chem. 65: 625-632.

Block, E., Naganathan, S., Putman, D., and Zhao, S.H. (1993b). Garlic and onion chemistry. Chemistry International. 15: 178-180.

Block, E. (1994). Flavorants from garlic, onion, and other Alliums and their cancer preventitive properties. Food Phytochemicals for Cancer Prevention. In: Huang, M.T., Osawa, T., Ho, C.T., and Rosen, R.T. (Ed.). American Chemical Society, Washington DC, pp. 84-96.

Block, E., and Thiruvazhi, M. (1993). Allium chemistry: Synthesis of alk(en) yl 3,4-dimethyl-2-thienyl disulfides, components of distilled oils and extracts of Allium species. J. Agric. Food Chem. 41(12): 2235-2237.

Boban, P.T., Nambisan, B., and Sudhakaran, P.R. (2006). Hypolipidaemic effect of chemically different mucilages in rats: a comparative study. British J. Nutr.96: 1021-1029.

Bordia, A., Verma, S.K., and Srivastava, K.C. (1997). Effect of ginger (Zingiber officinale Rosc.) and fenugreek (Trigonella foenumgraecum L.) on blood lipids, blood sugar and platelet aggregation in patients with coronary artery disease. Prostaglandins Leukot Essent Fatty Acids. 56(5): 379-384.

Bordia, A., Verma, S.K., and Srivastava, K.C. (1998). Effect of garlic (Allium sativum) on blood lipids, blood sugar, fibrinogen and fibrinolytic activity in patients with coronary artery disease. Prostaglandins Leukot Essent Fatty Acids. 58(4): 257-263.

Bordoloi, D., Roy, N.K., Monisha, J., Padmavathi, G., and Kunnumakkara, A.B. (2016). Multi targeted agents in cancer cell chemosensitization: what we learnt from curcumin thus far. Recent Pat. Anticancer Drug Discov. 11(1): 67-97.

Borek, C. (2006). Garlic reduces dementia and heart-disease risk. J. Nutr. 136(3 Suppl): 810S-812S.

Bouhnik, Y., Raskine, L., Simoneau, G., Vicaut, E., Neut, C., Flourié, B.,
Brouns, F., and Bornet, F.R. (2004). The capacity of nondigestible carbohydrates to stimulate fecal bifidobacteria in healthy humans: double-blind, randomized, placebo-controlled, parallel-group, doseresponse relation study. Am. J. Clin. Nutr. 80(6): 1658-1664.

Budoff, M.J., Ahmadi, N., Gul, K.M., Liu, S.T., Flores, F.R., Tiano, J., Takasu, J., Miller, E., and Tsimikas, S. (2009). Aged garlic extract supplemented with $B$ vitamins, folic acid and L-arginine retards the progression of subclinical atherosclerosis: a randomized clinical trial. Prev. Med. 49(2-3): 101-107.

Bundy, R., Walker, A.F., Middleton, R.W., and Booth, J. (2004). Turmeric extract may improve irritable bowel syndrome symptomology in otherwise healthy adults: a pilot study. J. Altern. Complement. Med. 10(6): 1015-1018.

Burri, B.J. (2000). Retinoids and cancer prevention: crossing the line between food and drug. Nutrition 16: 1100-1101.

Butt, M.S., Sultan, M.T., Butt, M.S., and Iqbal, J. (2009). Garlic: nature's protection against physiological threats. Crit Rev Food Sci Nutr. 49(6): 538-551.

Byrne, A., Makadia, S., Sutherland, A., and Miller, M. (2017). Optimizing Non-Pharmacologic Management of Hypertriglyceridemia. Arch. Med. Res. 48(6): 483-487.

Calabrese, V., Scapagnini, G., Catalano, C., Dinotta, F., Geraci, D., and Morganti, P. (2000). Biochemical studies of a natural antioxidant isolated from rosemary and its application in cosmetic dermatology. Int. J. Tissue React. 22(1): 5-13.

Camacho, S., Michlig, S., de Senarclens-Bezençon, C., Meylan, J., Meystre, J., Pezzoli, M., Markram, H., and le Coutre, J. (2015). Anti-obesity and anti-hyperglycemic effects of cinnamaldehyde via altered ghrelin secretion and functional impact on food intake and gastric emptying. Sci. Rep. 5: 7919-7920.

Cao, H., Urban, J.F., and Anderson, R.A. (2008). Cinnamon polyphenol extract affects immune responses by regulating anti- and proinflammatory and glucose transporter gene expression in mouse macrophages. J. Nutr. 138(5): 833-840.

Cashman, J.R., Ghirmai, S., Abel, K.J., and Fiala, M. (2008). Immune defects in Alzheimer's disease: new medications development. BMC Neurosci. 9(Suppl 2): S13-S21.

Cassidy, A. (2018). Berry anthocyanin intake and cardiovascular health, Mol. Aspects Med.61: 76-82.

Cassidy, A., Mukamal, K.J., Liu, L., Franz, M., Eliassen, A.H., and Rimm, E.B. (2013). High anthocyanin intake is associated with a reduced risk of myocardial infarction in young and middle-aged women. Circulation. 127: 188-196.

Cassidy, A., Rogers, G., Peterson, J.J., Dwyer, J.T., Lin, H., and Jacques, P.F. (2015). Higher dietary anthocyanin and flavonol intakes are associated with anti-inflammatory effects in a population of US adults. Am J. Clin. Nutr. 102: 172-181.

Cassidy, A., Bertoia, M., Chiuve, S., Flint, A., Forman, J., and Rimm, E.B. (2016). Habitual intake of anthocyanins and flavanones and risk of cardiovascular disease in men. Am. J. Clin. Nutr. 104: 587-594.

Chaiyata, P., Puttadechakum, S., and Komindr, S. (2003). Effect of chili pepper (Capsicum frutescens) ingestion on plasma glucose response and metabolic rate in Thai women. J. Med. Assoc. Thai. 86(9): 854-860.

Chaiyasit, K., Khovidhunkit, W., and Wittayalertpanya, S. (2009). Pharmacokinetic and the effect of capsaicin in Capsicum frutescens on decreasing plasma glucose level. J. Med. Assoc. Thai. 92(1): 108-113.

Chandrashekar, P.M., and Venkatesh, Y.P. (2009). Identification of the protein components displaying immunomodulatory activity in aged garlic extract. J. Ethnopharmacol. 124(3): 384-490.

Chase, C.K., and McQueen, C.E. (2007). Cinnamon in diabetes mellitus. Am. J. Health Syst. Pharm. 64(10): 1033-1035.

Chauhan, N.B., and Sandoval, J. (2007). Amelioration of early cognitive deficits by aged garlic extract in Alzheimer's transgenic mice. Phytother. Res. 21(7): 629-640.

Cheng, T.C., Lin, C.S., Hsu, C.C., Chen, L.J., Cheng, K.C., and Vheng, J.T. (2009). Activation of muscarinic M-1 cholinoceptors by curcumin to increase glucose uptake into skeletal muscle isolated from Wistar rats. Neurosci. Lett. 465(3): 238-241.

Cheung, S., and Tai, J. (2007). Anti-proliferative and antioxidant properties of rosemary Rosmarinus officinalis. Oncol. Rep. 17(6): 1525-1531.

Chevassus, H., Molinier, N., Costa, F., Gabillaud, I., Mas, E., Dupuy, A.M., 
Michel, F., Cantie, C., Renard, E., Galtier, F., and Petit, P. (2010). A fenugreek seed extract selectively reduces spontaneous fat consumption in healthy volunteers. Eur. J. Clin. Pharmacol. 66(5): 449-455.

Cho, Y.H., Kim, N.H., Khan, I., Yu, J.M., Jung, H.G., Kim, H.H., Jang, J.Y., Kim, H.J., Kim, D.I., Kwak, J.H., Kang, S.C., and An, B.J. (2016). Anti-inflammatory potential of quercetin-O- $\beta$-d-(" 2 "-galloyl)-glucopyranoside and quercetin isolated from Diospyros kaki calyx via suppression of MAP signaling molecules in LPS induced RAW 264.7 macrophages. J. Food Sci. 81(10): C2447-C2456.

Chopan, M., and Littenberg, B. (2017). The Association of Hot Red Chili Pepper Consumption and Mortality: A Large Population-Based Cohort Study. PLoS ONE 12(1): e0169876.

Chrubasik, S., Pittler, M.H., and Roufogalis, B.D. (2005). Zingiberis rhizoma: a comprehensive review on the ginger effect and efficacy profiles. Phytomedicine. 12(9): 684-701.

Cianciulli, A., Calvello, R., Porro, C., Trotta, T., Salvatore, R., and Panaro, M.A. (2016). PI3k/Akt signalling pathway plays a crucial role in the anti-inflammatory effects of curcumin in LPS-activated microglia. Int. Immunopharmacol. 36: 282-290.

Costabile, A., Deaville, E.R., Morales, A.M., and Gibson, G.R. (2016). Prebiotic potential of a maize-based soluble fibre and impact of dose on the human gut microbiota. PloS one. 11(1): e0144457.

Costello, R.B., Dwyer, J.T., Saldanha, L., Bailey, R.L., Merkel, J., and Wambogo, E. (2016). Do cinnamon supplements have a role in glycemic control in Type 2 diabetes? A narrative. J. Acad. Nutr. Diet. 116(11): 1794-1802.

Dabaghzadeh, F., Khalili, H., Dashti-Khavidaki, S., Abbasian, L., and Moeinifard, A. (2014). Ginger for prevention of antiretroviral-induced nausea and vomiting: a randomized clinical trial. Expert Opin. Drug Saf 13(7): 859-866.

De, R., Kundu, P., Swarnakar, S., Ramamurthy, T., Chowdhury, A., Nair, G.B., and Mukhopadhyay, A.K. (2009). Antimicrobial activity of curcumin against Helicobacter pylori isolates from India and during infections in mice. Antimicrob. Agents Chemother. 53(4): 1592-1597.

Dearlove, R.P., Greenspan, P., Hartle, D.K., Swanson, R.B., and Hargrove, J.L. (2008). Inhibition of protein glycation by extracts of culinary herbs and spices. J. Med. Food. 11(2): 275-281.

Delcour, J.A., Aman, P., Courtin, C.M., Hamaker, B.R., and Verbeke, K. (2016). Prebiotics, fermentable dietary fiber, and health claims. Adv. Nutr. 7(1): 1-4.

Delecroix, B., Abaïdia, A.E., Leduc, C., Dawson, B., and Dupont, G. (2017). Curcumin and piperine supplementation and recovery following exercise induced muscle damage: A randomized controlled trial. J. Sports Sci. Med. 16(1): 147-153.

Delgado-Vargas, F., Jimenez, A.R., and Paredes-Lopes, O. (2000). Natural pigments: carotenoids, anthocyanins, and betalains - characteristics, biosynthesis, processing, and stability. Crit. Rev. Food Sci. Nutr. 40(3): 173-289.

Depeint, F., Tzortzis, G., Vulevic, J., I'Anson, K., and Gibson, G.R. (2008). Prebiotic evaluation of a novel galactooligosaccharide mixture produced by the enzymatic activity of Bifidobacterium bifidum NCIMB 41171, in healthy humans: a randomized, double-blind, crossover, placebo-controlled intervention study. Am. J. Clin. Nutr. 87(3): 785791.

Dewulf, E.M., Cani, P.D., Claus, S.P., Fuentes, S., Puylaert, P.G., Neyrinck, A.M., Bindels, L.B., de Vos, W.M., Gibson, G.R., Thissen, J.P., and Delzenne, N.M. (2013). Insight into the prebiotic concept: lessons from an exploratory, double blind intervention study with inulin-type fructans in obese women. Gut. 62(8): 1112-1121.

Devaraj, S., Autret, B.C., and Jialal, I. (2006). Reduced-calorie orange juice beverage with plant sterols lowers $\mathrm{C}$-reactive protein concentrations and improves the lipid profile in human volunteers. Am. J. Clin. Nutr. 84(4): 756-761.

Diepvens, K., Westerterp, K.R., and Westerterp-Plantenga, M.S. (2007). Obesity and thermogenesis related to the consumption of caffeine, ephedrine, capsaicin, and green tea. Am. J. Physiol. Regul. Integr Comp. Physiol. 292(1): R77-85.

Di Mario, F., Cavallaro, L.G., Nouvenne, A., Stefani, N., Cavestro, G.M., Loi, V., Maino, M., Comparato, G., Fanigliulo, L., Morana, E., Pilotto, A., Martelli, L., Martelli, M., Leandro, G., and Franze, A. (2007). A curcumin-based 1-week triple therapy for eradication of Helicobacter pylori infection: something to learn from failure? Helicobacter. 12(3): 238-243.

Di Pierro, F., Bressan, A., Ranaldi, D., Rapacioli, G., Giacomelli, L., and Bertuccioli, A. (2015). Potential role of bioavailable curcumin in weight loss and omental adipose tissue decrease preliminary data of a randomized, controlled trial in overweight people with metabolic syndrome. Preliminary study. Eur. Rev. Med. Pharmacol. Sci. (21): 4195-202.

Dodda, D., Chhajed, R., and Mishra, J. (2014). Protective effect of quercetin against acetic acid induced inflammatory bowel disease (IBD) like symptoms in rats: possible morphological and biochemical alterations. Pharmacol. Rep. 66(1): 169-173.

Dongare, S., Gupta, S.K., Mathur, R., Saxena, R., Mathur, S., Agarwal, R., Nag, T.C., Srivastava, S., and Kumar, P. (2016). Zingiber officinale attenuates retinal microvascular changes in diabetic rats via anti-inflammatory and antiangiogenic mechanisms. Molecular Vision. 22: 599-609.

Drobiova, H., Thomson, M., Al-Qattan, K., Peltonen-Shalaby, R., Al-Amin, Z., and Ali, M. (2009). Garlic increases antioxidant levels in diabetic and hypertensive rats determined by a modified peroxidase method. Evid.-Based Complement. Alternat. Med. 2011: 703049-703057.

Duenas, M., Munoz-Gonzalez, I., Cueva, C., Jimenez-Giron, A., SanchezPatan, F., Santos-Buelga, C., Moreno-Arribas, M.V., and Bartolome, B. (2015). A survey of modulation of gut microbiota by dietary polyphenols. Biomed. Res. Int. 2015: 850902.

Dugasani, S., Pichika, M.R., Nadarajah, V.D., Balijepalli, M.K., Tandra, S., and Korlakunta, J.N. (2010). Comparative antioxidant and antiinflammatory effects of [6]-gingerol, [8]-gingerol, [10]-gingerol and [6]-shogaol. J. Ethnopharmacol. 127(2): 515-520.

Durak, I., Oztürk, H.S., Olcay, E., and Guven, C. (2002). Effects of garlic extract supplementation on blood lipid and antioxidant parameters and atherosclerotic plaque formation process in cholesterol-fed rabbits. J. Herb. Pharmacother. 2(2): 19-32.

Durak, I., Aytaç, B., Atmaca, Y., Devrim, E., Avci, A., Erol, C., and Oral, D. (2016). Effects of garlic extract consumption on plasma and erythrocyte antioxidant parameters in atherosclerotic patients. Life Sci. 75(16): 1959-1966.

Ebrahimzadeh, A.V., Ostadrahimi, A., Asghari, J.M., Mehralizadeh, S., and Mahluji, S. (2016). Changes of serum adipocytokines and body weight following Zingiber officinale supplementation in obese women: a RCT. Eur. J. Nutr. 55(6): 2129-2136.

Effendy, J.L., Simmons, D.L., Campbell, G.R., and Campbell, J.H. (1997). The effect of the aged garlic extract, "Kyolic," on the development of experimental atherosclerosis. Atherosclerosis. 132: 37-42.

Ejaz, A., Wu, D., Kwan, P., and Meydani, M. (2009). Curcumin inhibits adipogenesis in 3T3-L1 adipocytes and angiogenesis and obesity in C57/ BL mice. J. Nutr. 139(5): 919-925.

El-Nezami, H.S., Polychronaki, N.N., Ma, J., Zhu, H., Ling, W., Salminen, E.K., Juvonen, R.O., Salminen, S.J., Poussa, T., and Mykkänen, H.M (2006). Probiotic supplementation reduces a biomarker for increased risk of liver cancer in young men from Southern China. Am. J. Clin. Nutr. 83(5): 1199-1203.

Espín, J.C., González-Sarrías, A., and Tomás-Barberán, F.A. (2017). The gut microbiota: A key factor in the therapeutic effects of (poly)phenols. Biochem. Pharmacol. 139: 82-93.

Fabio, A., Cermelli, C., Fabio, G., Nicoletti, P., and Quaglio, P. (2007) Screening of the antibacterial effects of a variety of essential oils on microorganisms responsible for respiratory infections. Phytother. Res. 21(4): 374-377.

Fairlie-Jones, L., Davison, K., Fromentin, E., and Hill, A.M. (2017). The effect of anthocyanin-rich foods or extracts on vascular function in adults: A systematic review and meta-analysis of randomised controlled trials. Nutrients. 9(8): 908-931.

Fang, X.D., Yang, F., Zhu, L., Shen, Y.L., Wang, L.L., and Chen, Y.Y. (2009). Curcumin ameliorates high glucose-induced acute vascular endothelial dysfunction in rat thoracic aorta. Clin. Exp. Pharmacol. Physiol. 36(120): 1177-1182.

Ferri, N., Yokoyama, K., Sadilek, M., Paolettei, R., Apitz-Castro, R., Gelb, M.H., and Corsini, A. (2003). Ajoene, a garlic compound, inhibits protein prenylation and arterial smooth muscle cell proliferation. $\mathrm{Br}$. J. Pharmacol. 138(5): 811-818 
Fouda, A.M., and Berika, M.Y. (2009). Evaluation of the effect of hydroalcoholic extract of Zingiber officinale rhizomes in rat collagen-induced arthritis. Basic Clin. Pharmacol. Toxicol. 104(3): 262-271.

Fraga, C.G., Croft, K.D., Kennedy, D.O., and Tomás-Barberán, F.A. (2019). The effects of polyphenols and other bioactives on human health. Food Funct. 10: 514-529.

Fukao, H., Yoshida, H., Tazawa, Y., and Hada, T. (2007). Antithrombotic effects of odorless garlic powder both in vitro and in vivo. Biosci. Biotechnol. Biochem. 71(1): 84-90.

Funk, J.L., Frye, J.B., Oyarzo, J.N., and Timmermann, B.N. (2009). Comparative effects of two gingerol-containing Zingiber officinale extracts on experimental rheumatoid arthritis. J. Nat. Prod. 72(3): 403-407.

Galeone, C., Pelucchi, C., Dal Maso, L., Negri, E., Montella, M., Zucchetto, A., Talamini, R., and La Vecchia, C. (2009a). Allium vegetables intake and endometrial cancer risk. Public Health Nutr. 12(9): 1576-1579.

Galeone, C., Tavani, A., Pelucchi, C., Negri, E., and La Vecchia, C. (2009b). Allium vegetable intake and risk of acute myocardial infarction in Italy. Eur. J. Nutr. 48(2): 120-123.

Galisteo, M., Suárez, A., Montilla, M.P., Torres, M.I., Gil, A., and Navarro, M.C. (2006). Protective effects of Rosmarinus tomentosus ethanol extract on thioacetamide-induced liver cirrhosis in rats. Phytomedicine. 13(1-2): 101-108.

García-Conesa, M.T., Chambers, K., Combet, E., Pinto, P., Garcia-Aloy, M., Andrés-Lacueva, C., de Pascual-Teresa, S., Mena, P., Ristic, A.K., Hollands, W.J., Kroon, P.A., Rodríguez-Mateos, A., Istas, G., A. Kontogiorgis, C.A., Rai, D.K., Gibney, E.R., Morand, C., Espín, J.C., and GonzálezSarrías, A. (2018). Meta-analysis of the effects of foods and derived products containing ellagitannins and anthocyanins on cardiometabolic biomarkers: Analysis of factors influencing variability of the individual responses. Int. J. Mol. Sci. 19(3): 694-727.

Gardi, C., Bauerova, K., Stringa, B., Kuncirova, V., Slovak, L., Ponist, S., Drafi, F., Bezakova, L., Tedesco, I., Acquaviva, A., Bilotto, S., and Russo, G.L. (2015). Quercetin reducedinflammation and increased antioxidant defense in rat adjuvant arthritis. Arch. Biochem. Biophys. 583: 150157.

Gardner, C.D., Lawson, L.D., Block, E., Chatterjee, L.M., Klazand, A., Balise, R.R., and Kraemer, H.C. (2007). Effect of raw garlic vs commercial garlic supplements on plasma lipid concentrations in adults with moderate hypercholesterolemia: a randomized clinical trial. Arch. Intern. Med. 167(4): 346-353.

Ge, Q., Cheng, L., and Chen, K. (2017). Treatment of diabetes mellitus using iPS cells and spice polyphenols. J. Diabetes Res. 2017: 5837804.

Ghayur, M.N., Gilani, A.H., Afridi, M.B., and Houghton, P.J. (2005). Cardiovascular effects of ginger aqueous extract and its phenolic constituents are mediated through multiple pathways. Vascul. Pharmacol. 43(4): 234-241

Goh, Y.J., and Klaenhammer, T.R. (2015). Genetic mechanisms of prebiotic oligosaccharide metabolism in probiotic microbes. Ann. Rev. Food Sci. Technol. 6(4): 137-156

Gonen, A., Harats, D., Rabinkov, A., Miron, T., Mirelman, D., Wilchek, M., Weiner, L., Ulman, E., Ben-Shushan, D., and Shalsh, A. (2005). The antiatherogenic effect of allicin: possible mode of action. Pathobiology. 72(6): 325-334

Gongadze, N., Antelava, N., Kezeli, T., Okudjava, M., and Pachokoria, K. (2008). The mechanisms of neurodegenerative processes and current pharmacotherapy of Alzheimer's disease. Georgian Med. News. (155): 44-48.

Gooze Goozee, K.G., Shah, T.M., Sohrabi, H.R., Rainey-Smith, S.R., Brown, B., Verdile, G., and Martins, R.N. (2016). Examining the potential clinical value of curcumin in the prevention and diagnosis of Alzheimer's disease. Br. J. Nutr. 115(3): 449-465.

Gopalpura, P.B., Jayanthi, C., and Dubey, S. (2007). Effect of Trigonella foenum-graecum seeds on the glycemic index of food: a clinical evaluation. Int. J. Diab. Dev. Ctries. 27: 4145

Gorgani, L., Mohammadi, M., Najafpour, G.D., and Nikzad, M. (2017). Piperine-the bioactive compound of black pepper: from isolation to medicinal formulations. Compr. Rev. in Food Sci. Food Saf. 16 124-140.

Gorinstein, S., Jastrzebski, Z., Namiesnik, J., Leontowicz, H., and Trakhtenberg, S. (2007). The atherosclerotic heart disease and protecting properties of garlic: contemporary data. Mol. Nutr. Food Res. 51(11):
$1365-1381$

Gould, K. (2004). Nature's Swiss army knife: The diverse protective roles of anthocyanins in leaves. J. Biomed. Biotech. 2004(5): 314-320.

Gruenwald, J., Freder, J., and Armbruester, N. (2010). Cinnamon and health. Crit. Rev. Food Sci. Nutr. 50(9): 822-834.

Grzanna, R., Phan, P., Polotsky, A., Lindmark, L., and Frondoza, C.G. (2004) Ginger extract inhibits beta-amyloid peptide-induced cytokine and chemokine expression in cultured THP-1 monocytes. J. Altern. Complement. Med. 10(6): 1009-1013.

Gupta, V.B., Indi, S.S., and Rao, K.S. (2009). Garlic extract exhibits antiamyloidogenic activity on amyloid-beta fibrillogenesis: relevance to Alzheimer's disease. Phytother. Res. 23(1): 111-115.

Gupta, J.S., Puri, S., Misra, A., Gulati, S., and Mani, K. (2017). Effect of oral cinnamon intervention on metabolic profile and body composition of Asian Indians with metabolic syndrome: a randomized double -blind control trial. Lipids Health Dis. 16(1): 13-22.

Gutierrez, J.L., Bowden, R.G., and Willoughby, D.S. (2016). Cassia cinnamon supplementation reduces peak blood glucose responses but does not improve insulin resistance and sensitivity in young, sedentary, obese women. J. Diet. Suppl. 13(4): 461-471.

Han, L.K., Morimoto, C., and Zheng, Y.N. (2008). Effects of zingerone on fat storage in ovariectomized rats. Yakugaku Zasshi. 128(8): 1195-1201.

Hanai, H., lida, T., Takeuchi, K., Watanabe, F., Maruyama, Y., Andoh, A., Tsujikawa, T., Fujiyama, T., Fujiyama, Y., Mitsuyama, K., Sata, M., Yamada, M., Iwaoka, Y., Kanke, K., Hiraishi, H., Hirayama, K., Arai, H., Yoshi, S., Uchijima, M., Nagata, T., and Koide, Y. (2006). Curcumin maintenance therapy for ulcerative colitis: randomized, multicenter, double-blind, placebo-controlled trial. Clin. Gastroenterol. Hepatol. 4(12): 1502-1506.

Handa, T., Yamaguchi, K., Sono, Y., and Yazawa, K. (2005). Effects of fenugreek seed extract in obese mice fed a high-fat diet. Biosci. Biotechnol. Biochem. 69(6): 1186-1188.

Handelman, G.J. (2001). The evolving role of carotenoids in human biochemistry. Nutrition. 17(10): 818-822.

Hannan, J.M., Ali, L., Rokeya, B., Khaleque, J., Akter, M., Flatt, P.R., and Abdel-Wahab, Y.H. (2007). Soluble dietary fibre fraction of Trigonella foenum-graecum (fenugreek) seed improves glucose homeostasis in animal models of type 1 and type 2 diabetes by delaying carbohydrate digestion and absorption, and enhancing insulin action. Br. J. Nutr. 97(3): 514-521.

Harach, T., Aprikian, O., Monnard, I., Moulin, J., Membrez, M., Beolor, J.C., Raab, T., Mace, K., and Darimont, C. (2010). Rosemary (Rosmarinus officinalis L.) leaf extract limits weight gain and liver steatosis in mice fed a high-fat diet. Planta Med. 76(6): 566-571.

Harborne, J.B., and Williams, C.A. (2000). Advances in flavonoid research since 1992. Phytochemistry. 55(6): 481-504.

Hariri, M., and Ghiasvand, R. (2016). Cinnamon and chronic diseases. Adv. Exp. Med. Biol. 929: 1-24.

Harris, W.S., Mozaffarian, D., Lefevre, M., Toner, C.D., Colombo, J., Cun nane, S.C., Holden, J.M., Klurfeld, D.M., Morris, M.C., and Whelan, J. (2009). Towards establishing dietary reference intakes for eicosapentaenoic and docosahexaenoic acids. Nutr. 139(4): 804S-8019S.

Haroyan, A., Mukuchyan, V., Mkrtchyan, N., Minasyan, N., Gasparyan, S., Sargsyan, A., Narimanyan, M., and Hovhannisyan, A. (2018). Efficacy and safety of curcumin and its combination with boswellic acid in osteoarthritis: a comparative, randomized, double-blind, placebocontrolled study. BMC Complement. Altern. Med. 18(7): 1-26.

Hassan, H.A., El-Agmy, S.M., Gaur, R.L., Fernando, A., Raj, M.H., and Ouhtit, A. (2009). In vivo evidence of hepato- and reno-protective effect of garlic oil against sodium nitrite-induced oxidative stress. Int. J. Biol. Sci. 5(3): 249-255.

Hassan, Z.M., Yaraee, R., Zare, N., Ghazanfari, T., Nejad, A.H.S., and Nazori, B. (2003). Immunomodulatory affect of R10 fraction of garlic extract on natural killer activity. Int. Immunopharmacol. 3(10-11): 1483-1489.

He, Z., Chen, H., Li, G., Zhu, H., Gao, Y., Zhang, L., and Sun, J. (2014). Diosgenin inhibits the migration of human breast cancer MDA-MB-231 cells by suppressing Vav2 activity. Phytomedicine. 21(6): 871-876.

Hiyasat, B., Sabha, D., Grotzinger, K., Kempfert, J., Rauwald, J.W., Mohr, F.W., and Dhein, S. (2009). Antiplatelet activity of Allium ursinum and Allium sativum. Pharmacology. 83(4): 197-204. 
Ho, C.Y., Lu, C.C., Weng, C.J., and Yen, G.C. (2016). Protective effects of dialIyl sulfide on ovalbumin-induced pulmonary inflammation of allergic asthma mice by microRNA-144,-34a, and -34b/c-modulated Nrf2 activation. J. Agric.Food Chem. 64(1): 151-160.

Holzapfel, W.H., Haberer, P., Geisen, R., Björkroth, J., and Schillinger, U. (2001). Taxonomy and important features of probiotic microorganisms in food and nutrition. Am. J. Clin. Nutr. 73(2 Suppl): 365S-373S

Hou, X.F., Pan, H., Xu, L.H., Zha, Q.B., He, X.H., and Ouyang, D.Y. (2015). Piperine suppresses the expression of CXCL8 in lipopolysaccharideactivated SW480 and HT-29 cells via downregulating the mitogenactivated protein kinase pathways. Inflammation. 38(3): 1093-1102.

Hosseini, M., Shafiee, S.M., and Baluchnejadmojarad, T. (2007). Garlic extract reduces serum angiotensin converting enzyme (ACE) activity in nondiabetic and streptozotocin-diabetic rats. Pathophysiology. 14(2): 109-112.

Hsieh, C.L., Peng, C.H., Chyau, C.C., Lin, Y.C., Wang, H.E., and Peng, R.Y. (2007). Low-density lipoprotein, collagen, and thrombin models reveal that Rosemarinus officinalis L. exhibits potent antiglycative effects. J. Agric. Food Chem. 55(8): 2884-2891.

Hu, M.L., Frankel, E.N., Leibovitz, B.E., and Tappel, A.L. (1989a). Effect of dietary lipids and vitamin $\mathrm{E}$ on in vitro lipid peroxidation in rat liver and kidney homogenates. J. Nutr. 119(11): 1574-1582.

Huang, J., Wang, S., Luo, X., Xie, Y., and Shi, X. (2007). Cinnamaldehyde reduction of platelet aggregation and thrombosis in rodents. Thromb. Res. 119(3): 337-342.

Huang, H.C., Huang, C.Y., Lin-Shiau, S.Y., and Lin, J.K. (2009). Ursolic acid inhibits IL-1beta or TNF-alpha-induced C6 glioma invasion through suppressing the association ZIP/p62 with PKC-zeta and downregulating the MMP-9 expression. Mol. Carcinog. 48(6): 517-531.

Hutkins, R.W., Krumbeck, J.A., Bindels, L.B., Cani, P.D., Fahey, G., Goh, Y.J., Hamaker, B., Martens, E.C., Millds, D.A., Rastral, R.A., Vaughan, E., and Sanders, M.E. (2016). Prebiotics; why definitions matter. Curr. Opin. Biotechnol. 37: 1-7.

lacobellis, N.S., Lo Cantore, P., Capasso, F., and Senatore, F. (2005). Antibacterial activity of Cuminum cyminum $L$. and Carum carvi L. essential oils. J. Agric. Food Chem. 53(1): 57-61.

Iciek, M., Kwiecień, I., and Włodek, L. (2009). Biological properties of garlic and garlic-derived organosulfur compounds. Environ. Mol. Mutagen. 50(3): 247-265

Ikeuchi, M., Yamaguchi, K., Koyama, T., Sono, Y., and Yazawa, K. (2006). Effects of fenugreek seeds (Trigonella foenum greaecum) extract on endurance capacity in mice. J. Nutr. Sci. Vitaminol. 52(4): 287-592.

Ishikawa, H., Saeki, T., Otani, T., Suzuki, T., Shimozuma, K., Nishino, H. Fukuda, S., and Moritomo, K. (2006). Aged garlic extract prevents a decline of NK cell number and activity in patients with advanced cancer. J. Nutr. 136(3 Suppl): 816S-820S.

Ishrat, T., Hoda, M.N., Khan, M.B., Yousuf, S., Ahmad, M., Khan, M.M., Ahmad, A., and Islam, F. (2009). Amelioration of cognitive deficits and neurodegeneration by curcumin in rat model of sporadic dementia of Alzheimer's type (SDAT). Eur. Neuropsychopharmacol. 19(9): 636-647.

Jaganath, I.B., and Crozier, A. (2010). Dietary flavonoids and phenolic compounds. Dietary Flavonoids and Phenolic compounds. In: Fraga, C.G. (Ed.). John Wiley \& Sons, Hoboken, NJ, pp. 1-49.

Jaksevicius, A., Carew, M., Moditahedi, H., and Opara, E. (2017). Inhibitory Effects of Culinary Herbs and Spices on the Growth of HCA-7 Colorectal Cancer Cells and Their COX-2 Expression. Nutrients. 9(10): 1051-1073.

Jalal, R., Bagheri, S.M., Moghimi, A., and Rasuli, M.B. (2007). Hypoglycemic effect of aqueous shallot and garlic extracts in rats with fructoseinduced insulin resistance. J. Clin. Biochem. Nutr. 41(3): 218-223.

Janssens, P.L., Hursel, R., Martens, E.A., and Westerterp-Plantenga, M.S. (2013). Acute effects of capsaicin on energy expenditure and fat oxidation in negative energy balance. PLoS One. 8(7): e67786.

Janssens, P.L., Hursel, R., and Westerterp-Plantenga, M.S. (2014). Capsaicin increases sensation of fullness in energy balance and decreases desire to eat after dinner in negative energy balance. Appetite. 77: 44-49.

Jantaree, P., Lirdprapamongkol, K., Kaewsri, W., Thongsornkleeb, C., Choowongkomon, K., Atjanasuppat, K., Ruchirawat, S., and Svasti, J. (2017). Homodimers of vanillin and apocynin decrease the meta- static potential of human cancer cells by inhibiting the FAK/PI3K/Akt signaling pathway. J. Agric.Food Chem. 65(11): 2299-2306.

Jetté, L., Harvey, L., Eugeni, K., and Levens, N. (2009). 4-Hydroxyisoleucine: a plant-derived treatment for metabolic syndrome. Curr. Opin. Investig. Drugs. 10(4): 353-358.

Jeyabalan, J., Aqil, F., Soper, L., Schultz, D.J., and Gupta, R.C. (2015). Potent chemopreventive/antioxidant activity detected in common spices of the Apiaceae family. Nutr. Cancer. 67(7): 1201-1207.

Jiang, Y., Turgeon, D.K., Wright, B.D., Sidahmed, E., Ruffin, M.T., Brenner, D.E., Sen, A., and Zick, S.M. (2013). Effect of ginger root on cyclooxygenase-1 and 15-hydroxyprostaglandin dehydrogenase expression in colonic mucosa of humans at normal and increased risk for colorectal cancer. Eur. J. Cancer Prev. 22(5): 455-460.

Jiménez-Escrig, A., Santos-Hidalgo, A.B., and Saura-Calixto, F. (2006). Common sources and estimated intake of plant sterols in the Spanish diet. J. Agric. Food Chem. 54(9): 3462-3471.

Johnson, J.J., Nihal, M., Siddiqui, I.A., Scarlett, C.O., Bailey, H.H., Mukhtar, H., and Ahmad, N. (2011). Enhancing the bioavailability of resveratrol by combining it with piperine. Mol. Nutr. Food Res. 55(8): 1169-1176.

Juergens, U.R. (2014). Anti-inflammatory properties of the monoterpene 1.8-cineole: current evidence for co-medication in inflammatory airway diseases. Drug Res (Stuttg). 64(12): 638-646.

Jung, H.W., Yoon, C.H., Park, K.M., Han, H.S., and Park, Y.K. (2009). Hexane fraction of Zingiberis Rhizoma Crudus extract inhibits the production of nitric oxide and proinflammatory cytokines in LPS-stimulated BV2 microglial cells via the NF-kappaB pathway. Food Chem Toxicol. 47(6): 1190-1197.

Jurenka, J.S. (2009). Anti-inflammatory properties of curcumin, a major constituent of Curcuma longa: a review of preclinical and clinical research. Altern. Med. Rev. 14(2): 141-53.

Kaleem, M., Sheema, Sarmad, H., and Bano, B. (2005). Protective effects of Piper nigrum and Vinca rosea in alloxan induced diabetic rats. Indian J. Physiol. Pharmacol. 49(1): 65-71.

Kang, J.S., Kim, T.M., Shim, T.J., Salim, E.I., Han, B.S., and Kim, D.J. (2012). Modifying effect of diallyl sulfide on colon carcinogenesis in $\mathrm{C} 57 \mathrm{BL} / 6$ J-ApcMin/+ mice. Asian Pac. J. Cancer Prev. 13(4): 1115-1118.

Kang, C., Zhang, Y., Zhu, X., Liu, K., Wang, X., Chen, M., Wang, J., Chen, H., Hui, S., Huang, L., Zhang, Q., Zhu, J., Wang, B., and Mi, M. (2016) Healthy Subjects Differentially Respond to Dietary Capsaicin Correlating with Specific Gut Enterotypes. J. Clin. Endocrinol. Metab. 101(12): 4681-4689.

Kang, J.H., Kim, C.S., Han, I.S., Kawada, T., and Yu, R. (2007). Capsaicin, a spicy component of hot peppers, modulates adipokine gene expression and protein release from obese-mouse adipose tissues and isolated adipocytes, and suppresses the inflammatory responses of adipose tissue macrophages. FEBS Lett. 581(23): 4389-4396.

Kannappan, S., and Anuradha, C.V. (2009). Insulin sensitizing actions of fenugreek seed polyphenols, quercetin \& metformin in a rat model. Indian J. Med. Res. 129(4): 401-408.

Kanuri, G., Weber, S., Volynets, V., Spruss, A., Bischoff, S.C., and Bergheim, I. (2009). Cinnamon extract protects against acute alcohol-induced liver steatosis in mice. J. Nutr. 139(3): 482-487.

Kapoor, I.P., Singh, B., Singh, G., De Heluani, C.S., De Lampasona, M.P., and Cataln, C.A. (2009). Chemistry and in vitro antioxidant activity of volatile oil and oleoresins of black pepper (Piper nigrum). J. Agric. Food Chem. 57(12): 5358-5364.

Kapoor, I.P., Singh, B., and Singh, G. (2009). Chemistry and in vitro antioxidant activity of volatile oil and oleoresins of black pepper (Piper nigrum). J. Agric. Food Chem. 57(12): 5358-5364.

Karuppagounder, V., Arumugam, S., Thandavarayan, R.A., Sreedhar, R., Giridharan, V.V., and Watanabe, K. (2016). Molecular targets of quercetin with anti-inflammatory properties in atopic dermatitis. Drug Discov. Today. 21(4): 632-639.

Kawabata, K., Kawai, Y., and Terao, J. (2010). Suppressive effect of quercetin on acute stress-induced hypothalamicpituitary-adrenal axis response in Wistar rats. J. Nut. Biochem. 21: 374-380.

Kawatra, P., and Rajagopalan, R. (2015). Cinnamon: Mystic powers of a minute ingredient. Pharmacognosy Res. 7(Suppl 1): S1-6.

Keating, A., and Chez, R.A. (2002). Ginger syrup as an antiemetic in early pregnancy. Altern. Ther. Health Med. 8(5): 89-91.

Keophiphath, M., Priem, F., Jacquemond-Collet, I., Clement, K., and Laca- 
sa, D. (2009). 1,2-vinyldithiin from garlic inhibits differentiation and inflammation of human preadipocytes. J. Nutr. 139(11): 2055-2060.

Keys, A., and Parlin, R.W. (1966). Serum cholesterol response to changes in dietary lipids. Am. J. Clin. Nutr. 19(3): 175-181.

Khajuria, A., Thusu, N., and Zutshi, U. Piperine modulates permeability characteristics of intestine by inducing alterations in membrane dynamics: influence on brush border membrane fluidity, ultrastructure and enzyme kinetics. Phytomedicine 9(3): 224-231.

Khan, A., Vaibhav, K., Javed, H., Tabassum, R., Ahmed, M.E., Khan, M.M., Khan, M.B., Shrivastava, P., Islam, F., Siddiqui, M.S., Safhi, M.M., and Islam, F. (2014). 1,8-cineole (eucalyptol) mitigates inflammation in amyloid Beta toxicated PC12 cells: relevance to Alzheimer's disease. Neurochem Res. 39(2): 344-352.

Khonche, A., Biglarian, O., Panahi, Y., Valizadegan, G., Soflaei, S.S. Ghamarchehreh, M.E., Majeed, M., and Sahebkar, A. (2016). Adjunctive Therapy with Curcumin for Peptic Ulcer: a Randomized Controlled Trial. Drug Res. (Stuttg). 66(8): 444-448.

Kim, H.G., Han, E.H., Jang, W.S., Choi, J.H., Khanal, T., Park, B.H., Tran, T.P., Chung, Y.C., and Jeong, H.G. (2012). Piperine inhibits PMA-induced cyclooxygenase-2 expression through downregulating NF-KB, C/EBP and AP-1 signaling pathways in murine macrophages. Food Chem. Toxicol. 50(7): 2342-2348

Kim, D.S., Lee, H.J., Jeon, Y.D., Han, Y.H., Kee, J.Y., Kim, H.J., Shin, H.J., Kang, J., Lee, B.S., Kim, S.H., Kim, S.J., Park, S.H., Choi, B.M., Park, S.J., Um, J.Y., and Hong, S.H. (2015). Alphapinene exhibits anti-inflammatory activity through the suppression of MAPKs and the NF-KB pathway in mouse peritoneal macrophages. Am. J. Chin. Med. 43(4): 731-742.

Kim, S.H., Hong, J.H., and Lee, Y.C. (2013). Ursolic acid, a potential PPARY agonist, suppresses ovalbumin-induced airway inflammation and Penh by downregulating IL-5, IL-13, and IL-17 in a mouse model of allergic asthma. Eur. J Pharmacol. 701(1-3): 131-143.

Kim, D.H., Kim, C.H., Kim, M.S., Kim, J.Y., Jung, K.J., Chung, J.H., An, W.G., Lee, J.W., Yu, B.P., and Chung, H.Y. (2007). Suppression of age-related inflammatory NF-kappaB activation by cinnamaldehyde. Biogerontology. 8(5): 545-554.

Kim, D.S., Kim, J.Y., and Han, Y.S. (2007). Alzheimer's disease drug discovery from herbs: neuroprotectivity from beta-amyloid (1-42) insult. J. Altern. Complement. Med. 13(3): 333-340.

Kim, J.Y., and Kwon, O. (2009). Garlic intake and cancer risk: an analysis using the Food and Drug Administration's evidence-based review system for the scientific evaluation of health claims. Am. J. Clin. Nutr. 89: 257-264.

Kim, S.J., Kim, J.S., Cho, H.S., Lee, H.J., Kim, S.Y., Kim, S., Lee, S.Y., and Sung, C.H. (2006). Carnosol, a component of rosemary (Rosmarinus officinalis L.) protects nigral dopaminergic neuronal cells. Neuroreport. 17(16): 1729-1733.

Knott, E.J., Richard, A.J., Mynatt, R.L., Ribnicky, D., Stephens, J.M., and Bruce-Keller, A. (2017). Fenugreek supplementation during high-fat feeding improves specific markers of metabolic health. Sci. Rep. 7(1): 12770

Koe, X.F., Muhammad, T.S.T., Chong, A.S.C., Wahab, H.A., and Tan, M.L. (2014). Cytochrome P450 induction properties of food and herbalderived compounds using a novel multiplex RT-qPCR in vitro assay, a drug-food interaction prediction tool. Food Science \& Nutrition 2014 2(5): 500-520.

Koh, A., De Vadder, F., Kovatcheva-Datchary, P., and Backhed, F. (2016). From dietary fiber to host physiology: short-chain fatty acids as key bacterial metabolites. Cell. 165(6): 1332-1345.

Koscielny, J., Klussendorf, D., Latza, R., Schmitt, R., Radtke, H., Siegel, G., and Kiesewetter, H. (1999). The antiatherosclerotic effect of Allium sativum. Atherosclerosis. 144(1): 237-249.

Krga, I., Monfoulet, L.E., Konic-Ristic, A., Mercier, S., Glibetic, M., Morand C., and Milenkovic, D. (2016). Anthocyanins and their gut metabolites reduce the adhesion of monocyte to TNF $\alpha$-activated endothelia cells at physiologically relevant concentrations. Arch. Biochem. Biophys. 599: 51-59.

Krinsky, N.I. (2001). Carotenoids as antioxidants. Nutrition. 17(10): 815817

Kulinich, A., and Liu, L. (2016). Human milk oligosaccharides: the role in the fine-tuning of innate immune responses. Carbohydr. Res. 432: $62-70$.
Kumar, S., Singhal, V., Roshan, R., Sharma, A., Rembhotkar, G.W., and Ghosh, B. (2007). Piperine inhibits TNF-alpha induced adhesion of neutrophils to endothelial monolayer through suppression of NFkappaB and IkappaB kinase activation. Eur. J. Pharmacol. 575(1-3): 177-186.

Kundu, J.K., Na, H.K., and Surh, Y.J. (2009). Ginger-derived phenolic substances with cancer preventive and therapeutic potential. Forum Nutr. 61: 182-192.

Kunnumakkara, A.B., Bordoloi, D., Padmavathi, G., Monisha, J., Roy, N.K., Prasad, S., and Aggarwal, B.B. (2017). Curcumin, the golden nutraceutical: multitargeting for multiple chronic diseases. Br. J. Pharmacol. 174(11): 1325-1348.

Kunnumakkara, A., Sallo, B.L., Banik, K., Harsha, C., Prasad, S., Chandra Gupta, S., Chandra Bharti, A., and Aggarwal, B.B. (2018). Chronic diseases, inflammation and spices: how are they linked? J. Transl. Med. 16: 14 .

Kuptniratsaikul, V., Thanakhumtorn, S., Chinswangwantanakul, P., Wattanamongkonsil, L., and Thamlikitkul, V. (2009). Efficacy and safety of Curcuma domestica extracts in patients with knee osteoarthritis. J. Altern. Complement. Med. 15(8): 891-897.

Kwak, J.S., Kim, J.Y., Paek, J.E., Lee, Y.J., Kim, H.R., Park, D.S., and Kwon, O. (2014). Garlic powder intake and cardiovascular risk factors: a metaanalysis of randomized controlled clinical trials. Nutr. Res. Pract. 8(6): 644-654.

Kwon, Y.I., Vattem, D.A., and Shetty, K. (2006). Evaluation of clonal herbs of Lamiaceae species for management of diabetes and hypertension. Asia Pac. J. Clin. Nutr. 15(1): 107-118.

Lackova, Z., Buchtelova, H., Buchtova, Z., Klejdus, B., Heger, Z., Brtnicky, M., Kynicky, J., Zitka, O., and Adam, O. (2017). Anticarcinogenic effect of spices due to phenolic and flavonoid compounds - in vitro evaluation on prostate cells. Molecules. 22: 1626

Lau, B.H. (2006). Suppression of LDL oxidation by garlic compounds is a possible mechanism of cardiovascular health benefit. J. Nutr. 136(3 Suppl): 765S-768S

Lee, J.J., Jin, Y.R., Lee, J.H., Yu, J.Y., Han, X.H., Oh, K.W., Hong, J.T., Kim, T.J., and Yun, Y.P. (2007). Antiplatelet activity of carnosic acid, a phenolic diterpene from Rosmarinus officinalis. Planta Med. 73(2): 121-127.

Lei, Y.P., Chen, H.W., Sheen, L.Y., and Lii, C.K. (2008). Diallyl disulfide and diallyl trisulfide suppress oxidized LDL-induced vascular cell adhesion molecule and E-selectin expression through protein kinase A- and Bdependent signaling pathways. J. Nutr. 138(6): 996-1003.

Lei, Y.P., Liu, C.T., Sheen, L.Y., Chen, H.W., and Lii, C.K. (2010). Diallyl disulfide and diallyl trisulfide protect endothelial nitric oxide synthase against damage by oxidized low-density lipoprotein. Mol. Nutr. Food Res. 54(Suppl 1): S42-52.

Lejeune, M.P., Kovacs, E.M., and Westerterp-Plantenga, M.S. (2003). Effect of capsaicin on substrate oxidation and weight maintenance after modest body-weight loss in human subjects. Br. J. Nutr. 90(3): 651-659.

Levine, M.E., Gillis, M.G., Koch, S.Y., Voss, A.C., Stern, R.M., and Koch, K.L. (2008). Protein and ginger for the treatment of chemotherapy-induced delayed nausea. J. Altern. Complement Med. 14(5): 545-551.

Li, L.C., Piao, H.M., Zheng, M.Y., Lin, Z.H., Li, G., and Yan, G.H. (2016). Sesamin attenuates mast cell-mediated allergic responses by suppressing the activation of p38 and nuclear factor-kB. Mol. Med. Rep. 13(1): 536-542.

Li, X., Liu, H.C., Yao, Q.Y., Xu, B.L., Zhang, S.C., and Tu, C.T. (2016). Quercetin protects mice from ConA-induced hepatitis by inhibiting HMGB1-TLR expression and down-regulating the nuclear factor kappa B pathway. Inflammation. 39(1): 96-106.

Liang, Z., Xu, Y., Wen, X., Nie, H., Hu, T., Yang, X., Chu, X., Yang, J., Deng, X., and $\mathrm{He}, \mathrm{J}$. (2016). Rosmarinic acid attenuates airway inflammation and hyperresponsiveness in a murine model of asthma. Molecules. 21(6): 769-784.

Lirdprapamongkol, K., Sakurai, H., Kawasaki, N., Choo, M.K., Saitoh, Y., Aozuka, Y., Singhirunnusorn, P., Ruchirawat, S., Svasti, J., and Saiki, I. (2005). Vanillin suppresses in vitro invasion and in vivo metastasis of mouse breast cancer cells. Eur. J. Pharm. Sci. 25(1): 57-65.

Liu, C.T., Wong, P.L., Lii, C.K., Hse, H., and Sheen, L.Y. (2006). Antidiabetic effect of garlic oil but not diallyl disulfide in rats with streptozotocininduced diabetes. Food Chem. Toxicol. 44(8): 1377-1384. 
Liu, C.T., Hse, H., Lii, C.K., Chen, P.S., and Sheen, L.Y. (2005). Effects of garlic oil and diallyl trisulfide on glycemic control in diabetic rats. Eur. J. Pharmacol. 516(2): 165-173.

Louis, P., Flint, H.J., and Michel, C. (2016). How to manipulate the microbiota: prebiotics. Adv. Exp. Med. Biol. 902: 119-142.

Lobo, V., Patil, A., Phatak, A., and Chandra, N. (2010). Free radicals, antioxidants and functional foods: Impact on human health. Pharmacogn. Rev. 4(8): 118-126.

Lu, X.L., Zhao, C.H., Yao, X.L., and Zhang, H. (2017). Quercetin attenuates high fructose feeding-induced atherosclerosis by suppressing inflammation and apoptosis via ROS-regulated PI3K/AKT signaling pathway. Biomed. Pharmacother. 85: 658-671.

Lumb, A.B. (1994). Effect of dried ginger on human platelet function. Thromb Haemost. 71(1): 110-111.

Machado, D.G., Bettio, L.E., Cunha, M.P., Capra, J.C., Dalmarco, J.B., Pizzolatti, M.G., and Rodrigues, A.L. (2009). Antidepressant-like effect of the extract of Rosmarinus officinalis in mice: involvement of the monoaminergic system. Prog. Neuropsychopharmacol. Biol. Psychiatry. 33(4): 642-650.

Maciel, R.M., Costa, M.M., Martins, D.B., França, R.T., Schmatz, R., Graça, D.L., Duarte, M.M., Danesi, C.C., Mazzanti, C.M., Schetinger, M.R., Paim, F.C., Palma, H.E., Abdala, F.H., Stefanello, N., Zimpel, C.K., Felin, D.V., and Lopes, S.T. (2013). Antioxidant and anti-inflammatory effects ofquercetin in functional and morphological alterations in streptozotocin-induced diabetic rats. Res. Vet. Sci. 95(2): 389-397.

Mahdavi-Roshan, M., Zahedmehr, A., Mohammad-Zadeh, A., Sanato, H.R., Shakerian, F., Firouzi, A., Klani, R., and Nasrollahzadeh, J. (2013). Effect of garlic powder tablet on carotid intima-media thickness in patients with coronary artery disease: a preliminary randomized controlled trial. Nutr. Health. 22(2): 143-155.

Mahdavi-Roshan, M., Nasrollahzadeh, J., Mohammad Zadeh, A., and Zahedmehr, A. (2016). Does garlic supplementation control blood pressure in patients with severe coronary artery disease? A Clinical Trial Study. Iran Red Crescent Med. J. 18(11): e23871.

Maheshwari, A., Verma, N., Swaroop, A., Bagchi, M., Preuss, H.G., Tiwari, K., and Bagchi, D. (2017). Efficacy of Furosap TM, a novel Trigonella foenum-graecum seed extract, in enhancing testosterone level and improving sperm profile in male volunteers. Int. J. Med. Sci. 14(1): 58-66.

Mahluji, S., Attari, V.E., Mobasseri, M., Payahoo, L., Ostadrahimi, A., and Golzari, S.E. (2013). Effects of ginger (Zingiber officinale) on plasma glucose level, $\mathrm{HbA} 1 \mathrm{c}$ and insulin sensitivity in type 2 diabetic patients. Int. J. Food Sci. Nutr. 64(6): 682-686.

Maierean, S.M., Serban, M.C., Sahebkar, A., and Ursoniu, S. (2017). The effects of cinnamon supplementation on blood lipid concentrations: A systematic review and meta-analysis. J. Clin. Lipidol. 11(6): 13931406

Maki, K.C., Davidson, M.H., Umporowicz, D.M., Schaefer, E.J., Dicklin, M.R., Ingram, K.A., Chen, S., McNamanar, J.R., Gebhart, B.W., RibayaMercado, J.D., Perrone, G., Robins, S.J., and Franke, W.C. (2001a). Lipid responses to plant-sterol-enriched reduced-fat spreads incorporated into a National Cholesterol Education Program Step I. Am. J. Clin. Nutr. 74: 33-43.

Maki, K.C., and Rains, T.M. (2001b). Hypocholesterolemic effects of plant sterols and stanols: Do the dose-response curves diverge? Prostaglandins, Leukotrienes and Essential Fatty Acids 85: 5-6.

Maki, K.C., Lawless, A.L., Reeves, M.S., Kelley, K.M., Dicklin, M.R., Jenks, B.H., Shneyvas, E., and Brooks, J.R. (2013). Lipid effects of a dietary supplement softgel capsule containing plant sterols/stanols in primary hypercholesterolemia. Nutr. 29: 96-100.

Manikandan, P., Vinothini, R., Vidya Priyadarsini, D., and Nagini, P.S. (2011). Eugenol inhibits cell proliferation via NF-KB suppression in a rat model of gastric carcinogenesis induced by MNNG. Investigational New Drugs. 29(1): 110-117.

Manjunatha, H., and Srinivasan, K. (2007). Hypolipidemic and antioxidant effects of curcumin and capsaicin in high-fat-fed rats. Can. J. Physiol. Pharmacol. 85(6): 588-596.

Mansour, M.S., Ni, Y.M., Roberts, A.L., Kelleman, M., Roychoudhury, A., and St-Onge, M.P. (2012). Ginger consumption enhances the thermic effect of food and promotes feelings of satiety without affecting metabolic and hormonal parameters in overweight men: a pilot study. Metabolism. 61(10): 1347-1352

Mathern, J.R., Raatz, S.K., Thomas, W., and Slavin, J.L. (2009). Effect of fenugreek fiber on satiety, blood glucose and insulin response and energy intake in obese subjects. Phytother. Res. 23(11): 1543-1548.

Martin, R., Pierrard, C., Lejeune, F., Hilaire, P., Breton, L., and Bernerd, F. (2008). Photoprotective effect of a water-soluble extract of Rosmarinus officinalis L. against UV-induced matrix metalloproteinase-1 in human dermal fibroblasts and reconstructed skin. Eur. J. Dermatol. 18(2): 128-35.

Matsumura, M.D., Zavorsky, G.S., and Smoliga, J.M. (2015). The effects of pre-exercise ginger supplementation on muscle damage and delayed onset muscle soreness. Phytother. Res. 29(6): 887-893.

Muir, J.G., Yeow, E.G.W., Keogh, J., Pizzey, C., Bird, A.R., Sharpe, K., O’Dea, K., and Macrae, F.A. (2004). Combining wheat bran with resistant starch has more beneficial effects on fecal indexes than does wheat bran alone. Am. J. Clin. Nutr. 79: 1020-1028.

Mayo Clinic Staff. Mediterranean diet: A heart-healthy eating plan. Mayo Clinic. https://www.mayoclinic.org/healthy-lifestyle/nutrition-andhealthy-eating/in-depth/mediterranean-diet/art-20047801.

McCaffrey, R., Thomas, D.J., and Kinzelman, A.O. (2009). The effects of lavender and rosemary essential oils on test-taking anxiety among graduate nursing students. Holist. Nurs. Pract. 23(2): 88-93.

McKenney, J.M., Maki, K.C., Cook, C.M., Jenks, B.H., Shneyvas, E., Brooks, J.R., and Rains, T.M. (2012). Favorable lipid-altering effects of a softgel plant sterol/stanol dietary supplement in men and women with primary hypercholesterolemia. J. Clinical Lipidology. 6: 276-277.

Medagama, A.B. (2015). The glycaemic outcomes of Cinnamon, a review of the experimental evidence and clinical trials. Nutr. J. 14: 108-120.

Milenkovic, D., Morand, C., Cassidy, A., Konic-Ristic, A., Tomás-Barberán, F., Ordovas, J.M., Kroon, P., De Caterina, R., and Rodriguez-Mateos, A. (2017). Interindividual variability in biomarkers of cardiometabolic health after consumption of major plant-food bioactive compounds and the determinants involved. Adv. Nutr. 8(4): 558-570.

Milenkovic, D., Jude, B., and Morand, C. (2013). miRNA as molecular target of polyphenols underlying their biological effects. Free Radic. Biol. Med. 64: 40-51.

Miyamoto, M., Matsuzaki, K., Katakura, M., Hara, T., Tanabe, Y., and Shido, O. (2015). Oral intake of encapsulated dried ginger root powder hardly affects human thermoregulatory function, but appears to facilitate fat utilization. Int. J. Biometeorol. 59(10): 1461-1474.

Mollazadeh, H., and Hosseinzadeh, H. (2016). Cinnamon effects on metabolic syndrome: a review based on its mechanisms. Iran J. Basic Med. Sci. 19(12): 1258-1270.

Momtaz, S., Niaz, K., Maqbool, F., Abdollahi, M., Seyed, L., and Nabavi, M. (2017). STAT3 targeting by polyphenols: Novel therapeutic strategy for melanoma. Biofactors. 43(3): 347-370.

Mondal, S., and Pahan, K. (2015). Cinnamon ameliorates experimental allergic encephalomyelitis in mice via regulatory T cells: Implications for multiple sclerosis therapy. PLoS ONE 10(1): e0116566.

Moselhy, S.S., and Ali, H.K. (2009). Hepatoprotective effect of cinnamon extracts against carbon tetrachloride induced oxidative stress and liver injury in rats. Biol. Res. 42(1): 93-98.

Moss, M., Cook, J., Wesnes, K., and Duckett, P. (2003). Aromas of rosemary and lavender essential oils differentially affect cognition and mood in healthy adults. Int. J. Neurosci. 113(1): 15-38.

Mozaffari-Khosravi, H., Naderi, Z., Dehghan, A., Nadjarzadeh, A., and Fallah Huseini, H. (2016). Effect of ginger supplementation on proinflammatory cytokines in older patients with osteoarthritis: Outcomes of a randomized controlled clinical trial. J. Nutr. Gerontol. Geriatr. 35(3): 209-218.

Mózsik, G., Szolcsányi, J., and Rácz, I. (2005). Gastroprotection induced by capsaicin in healthy human subjects. World J. Gastroenterol. 11(33): 5180-5184.

Muhammad, J.S., Zaidi, S.F., Shaharyar, S., Refaat, A., Usmanghani, K., Saiki, I., and Sugiyama, T. (2015). Anti-inflammatory effect of cinnamaldehyde in Helicobacter pylori induced gastric inflammation. Biol. Pharm. Bull. 38(1): 109-115.

Mujumdar, A.M., Dhuley, J.N., Deshmukh, V.K., Raman, P.H., and Naik, S.R. (1990). Anti-inflammatory activity of piperine. Jpn. J. Med. Sci. Biol. 43: 95-100.

Naemura, A., Ura, M., Yamashita, T., Arai, R., and Yamamoto, J. (2008) 
Long-term intake of rosemary and common thyme herbs inhibits experimental thrombosis without prolongation of bleeding time. Thromb. Res. 122(4): 517-522.

Narender, T., Puri, A., Shweta, Khaliq, T., Saxena, R., Bhatia, G., and Chandra, R. (2005). 4-hydroxyisoleucine an unusual amino acid as antidyslipidemic and antihyperglycemic agent. Bioorg. Med. Chem. Lett. 16(2): 293-296.

Navekar, R., Rafraf, M., Ghaffari, A., Asghari-Jafarabadi, M., and Khoshbaten, M. (2017). Turmeric supplementation improves serum glucose indices and leptin levels in patients with nonalcoholic fatty liver iseases. J. Am. Coll. Nutr. 36(4): 261-267.

Nicoll, R., and Henein, M.Y. (2009). Ginger (Zingiber officinale Roscoe): a hot remedy for cardiovascular disease? Int. J. Cardiol. 131(3): 408409.

Nilius, B., and Appendino, G. (2013). Spices: the savory and beneficial science of pungency. Rev. Physiol. Biochem. Pharmacol. 164: 1-76.

Ng, T.P., Chiam, P.C., Lee, T., Chua, H.C., Lim, L., and Kua, E.H. (2006). Curry consumption and cognitive function in the elderly. Am. J. Epidemiol. 164(9): 898-906.

Ottaway, P.B. (2008). Food Fortification and Supplementation - Technological, Safety and Regulatory Aspects. CRC Press, Boca Raton, FL, p. 320.

Qian, B., Dawson, H., Polansky, M.M., and Anderson, R.A. (2009). Cinnamon extract attenuates TNF-alpha-induced intestinal lipoprotein ApoB48 overproduction by regulating inflammatory, insulin, and lipoprotein pathways in enterocytes. Horm. Metab. Res. 41(7): 51622.

Qian, B., Polansky, M.M., Sato, Y., Adeli, K., and Anderson, R.A. (2009). Cinnamon extract inhibits the postprandial overproduction of apolipoprotein B48-containing lipoproteins in fructose-fed animals. J. Nutr. Biochem. 20(11): 901-908.

Orhan, I., Aslan, S., Kartal, M., Sener, B., and Basar, H.C. (2008). Inhibitory effect of Turkish Rosmarinus officinalis on acetylcholinesterase and butyrylcholinesterase enzymes. Food Chem. 108: 663-668.

Ozgoli, G., Goli, M., and Simbar, M. (2009). Effects of ginger capsules on pregnancy, nausea, and vomiting. J. Altern. Complement. Med. 5(3): 243-246.

Pal, S.K., Reckamp, K., Yu, H., and Figlin, R.A. (2010). Akt inhibitors in clinical development for the treatment of cancer. Expert Opin. Investig. Drugs. 19(11): 1355-1366.

Panahi, Y., Alishiri, G.H., Parvin, S., and Sahebkar, A. (2016a). Mitigation of systemic oxidative stress by curcuminoids in osteoarthritis: Results of a randomized controlled trial. J. Diet. Suppl. 13(2): 209-220.

Panahi, Y., Hosseini, M.S., Khalili, N., Naimi, E., Simental-Mendia, L.E., Majeed, M., and Sahebkar, A. (2016b). Effects of curcumin on serum cytokine concentrations in subjects with metabolic syndrome: A posthoc analysis of a randomized controlled trial. Biomed. Pharmacother. 82: $578-582$.

Panahi, Y., Hosseini, M.S., Khalili, N., Naimi, E., Soflael, S.S., Majeed, M., and Sahebkar, A. (2016c). Effects of supplementation with curcumin on serum adipokine concentrations: A randomized controlled trial. Nutrition. 32(10): 1116-1122.

Panahi, Y., Kianpour, P., Mohtashami, R., Jafari, R., Simental-Mendia L.E., and Sahebkar, A. (2016d). Curcumin Lowers Serum Lipids and Uric Acid in Subjects With Nonalcoholic Fatty Liver Disease: A Randomized Controlled Trial. J. Cardiovasc. Pharmacol. 68(3): 223-229.

Panahi, Y., Khalili, N., Sahebi, E., Namazi, S., Reiner, Z., Majeed, M., and Sahebkar, A. (2017a). Curcuminoids modify lipid profile in type 2 mellitus: A randomized controlled trial. Complement. Ther. Med. 33: 1-5.

Panahi, Y., Kianpour, P., Mohtashami, R., Jafari, R., Simental-Mendia, L.E., and Sahebkar, A. (2017b). Efficacy and safety of phytosomal curcumin in non-alcoholic fatty liver disease: A randomized controlled trial. Drug Res. (Stuttg). 67(4): 244-251.

Pandurangan, A.K., Ismail, S., Saadatdoust, Z., and Esa, N.M. (2015). Allicin alleviates dextran sodium sulfate- (DSS-) induced ulcerative colitis in BALB/c mice. Oxid. Med. Cell. Longev. 2015: 605208.

Park, J.A., Kim, S., Lee, S.Y., Kim, C.S., Kim, D.K., Kim, S.J., and Chun, H.S. (2008). Beneficial effects of carnosic acid on dieldrin-induced dopaminergic neuronal cell death. Neuroreport. 19(13): 1301-1304.

Pearson, D.A., Frankel, E.N., Aeschbach, R., and German, B.J. (1997). Oxidation of low-density lipoprotein by rosemary and plant phenolics. J. Agric. Food Chem. 45(3): 578-582.
Peterson, D.W., George, R.C., Scaramozzino, F., LaPointe, N.E., Anderson, R.A., Graves, D.J., and Lew, J. (2009). Cinnamon extract inhibits tau aggregation associated with Alzheimer's disease in vitro. J. Alzheimers Dis. 17(3): 585-597.

Petit, P.R., Sauvaire, Y.D., Hillaire-Buys, D.M., Leconte, O.M., Baissac, Y.G., Ponsin, G.R., and Ribes, G.R. (1995). Steroid saponins from fenugreek seeds: extraction, purification, and pharmacological investigation on feeding behavior and plasma cholesterol. Steroids. 60(10): 674-680.

Petrovic, V., Nepal, A., Olaisen, C., Bachke, S., Hira, J., Søgaard, C.K., Røst L.M., Misund, K., Andreassen, T., Melø, T.M., Bartsova, Z., Bruheim, P., and Otterlei, M. (2018). Anti-cancer potential of homemade fresh garlic extract is related to increased endoplasmic reticulum stress. Nutrients. 10(4): 450

Pierre, S., Crosbie, L., and Duttaroy, A.K. (2005). Inhibitory effect of aqueous extracts of some herbs on human platelet aggregation in vitro. Platelets. 16(8): 469-673.

Platel, K., and Srinivasan, K. (2004). Digestive stimulant action of spices: a myth or reality? Indian J. Med. Res. 119: 167-179.

Pongrojpaw, D., Somprasit, C., and Chanthasenanont, A. (2007). A randomized comparison of ginger and dimenhydrinate in the treatment of nausea and vomiting in pregnancy. J. Med. Assoc. Thai. 90(9): 1703-1709.

Posadas, S.J., Caz, V., Largo, C., De la Gandara, B., Matallanas, B., Reglero, G., and De Miguel, E. (2009). Protective effect of supercritical fluid rosemary extract, Rosmarinus officinalis, on antioxidants of major organs of aged rats. Exp. Gerontol. 44(6-7): 383-389.

Pradeep, C.R., and Kuttan, G. (2004). Piperine is a potent inhibitor of nuclear factor-kappaB (NF-kappaB), c-Fos, CREB, ATF-2 and proinflammatory cytokine gene expression in B16F-10 melanoma cells. Int. Immunopharmacol. 4(14): 1795-1803.

Prasad, N.S., Raghavendra, R., Lokesh, B.R., and AkhilenderNaidua, K. (2004). Spice phenolics inhibit human PMNL 5-lipoxygenase. Prostaglandins Leukot. Essent. Fatty Acids. 70(6): 521-528.

Preuss, H.G., Echard, B., Polansky, M.M., and Anderson, R. (2006). Whole cinnamon and aqueous extracts ameliorate sucrose-induced blood pressure elevations in spontaneously hypertensive rats. J. Am. Coll. Nutr. 25(2): 144-150.

Rafraf, M., Malekiyan, M., Asghari-Jafarabadi, M., and Aliasgarzadeh, A. (2014). Effect of fenugreek seeds on serum metabolic factors and adiponectin levels in type 2 diabetic patients. Int. J. Vitam. Nutr. Res. 84(3-4): 196-205.

Rahman, K. (2007). Effects of garlic on platelet biochemistry and physiology. Mol. Nutr. Food Res. 51(11): 1335-1344.

Rahmani, S., Asgary, S., Askari, G., Keshvari, M., Hatamipour, M., Feizl, A., and Sahebkar, A. (2016). Treatment of non-alcoholic fatty liver disease with curcumin: A randomized placebo-controlled trial. Phytother. Res. 30(9): 1540-1548.

Rainey-Smith, S.R., Brown, B.M., Sohrabi, H.R., Shah, T., Goozee, K.G. Gupta, V.B., and Martins, R.N. (2016). Curcumin and cognition: randomised, placebo-controlled, double-blind study of communitydwelling older adults. Br. J. Nutr. 115(12): 2106-2113.

Rakhi, N.K., Tuwani, R., Mukherjee, J., and Bagler, G. (2018). Data-driven analysis of biomedical literature suggests broad-spectrum benefits of culinary herbs and spices. PLoS ONE 13(5): e0198030.

Ranasinghe, P., Jayawardena, R., Pigera, S., Wathurapatha, W.S., Weeratunga, H.D., Premakumara, G.A.S., Kataulanda, P., Constantine, G.R., and Galappaththy, P. (2017). Evaluation of pharmacodynamic properties and safety of Cinnamomum zeylanicum (Ceylon cinnamon) in healthy adults: a phase I clinical trial. BMC Complement Altern. Med. 28 17(1): 550-559.

Rao, A.V., and Agarwal, S. (2000). Role of antioxidant lycopene in cancer and heart disease. J. Am. Coll. Nutr. 19: 563-569.

Rao, A., Steels, E., Beccaria, G., Inder, W.J., and Vitetta, L. (2015). Influence of a specialized Trigonella foenum-graecum seed extract (Libifem), on testosterone, estradiol and sexual function in healthy menstruating women, a randomised placebo-controlled study. Phytother. Res 29(8): 1123-1130.

Rao, A., Steels, E., Inder, W.J., Abraham, S., and Vitetta, L. (2016). Testofen, a specialised Trigonella foenum-graecum seed extract reduces agerelated symptoms of androgen decrease, increases testosterone levels and improves sexual function in healthy aging males in a double- 
blind randomised clinical study. Aging Male. 19(2): 134-142.

Rao, P.V., and Gan, S.H. (2014). Cinnamon: a multifaceted medicinal plant. Evid. Based Complement Alternat. Med. 2014: 642942.

Rosengarten, F. Jr (1969). The Book of Spices. Livingston Publishing Company, Wynnewood, Pennsylvania, p. 345

Rakhi, N.K., Tuwani, R., Mukherjee, J., and Bagler, G. (2018). Data-driven analysis of biomedical literature suggests broad-spectrum benefits of culinary herbs and spices. PLoS One. 13(5): e0198030.

Ranganathan, S., Halagowder, D., and Sivasithambaram, N.D. (2015) Quercetin suppresses twist to induce apoptosis in MCF-7 breast cancer cells. PLoS ONE. 10(10): e0141370.

Rastall, R.A., and Gibson, G.R. (2015). Recent developments in prebiotics to selectively impact beneficial microbes and promote intestinal health. Curr. Opin. Biotechnol. 32: 42-46.

Rathi, B., Bodhankar, S., Mohan, V., and Thakurdesai, P. (2013). Ameliorative effects of a polyphenolic fraction of Cinnamomum zeylanicum L. bark in animal models of inflammation and arthritis. Sci. Pharm. 81(2): 567-589.

Rau, O., Wurglics, M., Paulke, A., Zitzkowski, J., Meindl, N., Bock, A., Dingermann, T., Abdel-Tawab, M., and Schubert-Zsilavecz, M. (2006) Carnosic acid and carnosol, phenolic diterpene compounds of the labiate herbs rosemary and sage, are activators of the human peroxisome proliferator-activated receptor gamma. Planta Med. 72(10): 881-887.

Reuter, S., Gupta, S.C., Chaturvedi, M.M., and Aggarwal, B.B. (2010). Oxidative stress, inflammation, and cancer: how are they linked? Free. Radic. Biol. Med. 49(11): 1603-1616.

Richelle, M., Enslen, M., Hager, C., Groux, M., Tavazzi, I., Godin, J.P., Berger, A., Métairon, S., Quaile, S., Piguet-Welsch, C., Sagalowicz, L., Green, H., and Bernard Fay, L. (2004). Both free and esterified plant sterols reduce cholesterol absorption and the bioavailability of $\beta$-carotene and $\alpha$-tocopherol in normocholesterolemic humans. Am. J. Clin. Nutr. 80: 171-177.

Rice-Evans, C.A., and Diplock, A.T. (1993). Current status of antioxidant therapy. Free Radic. Biol. Med. 15(1): 77-96.

Rinwa, P., and Kumar, A. (2012). Piperine potentiates the protective effects of curcumin against chronic unpredictable stress-induced cognitive impairment and oxidative damage in mice. Brain Res. 1488: 38-50.

Robert, S.D., Ismail, A.A., and Rosli, W.I. (2016). Reduction of postprandial blood glucose in healthy subjects by buns and flatbreads incorporated with fenugreek seed powder. Eur. J. Nutr. 55(7): 2275-2280.

Roberfroid, M., Gibson, G.R., Hoyles, L., McCartney, A.L., Rastall, R., Rowland, I., Wolvers, D., Watzl, B., Szajewska, H., Stahl, B., Guarner, F., Respondek, F., Whelan, K., Coxam, V., Davicco, M.J., Léotoing, L., Wittrant, Y., Delzenne, N.M., Cani, P.D., Neyrinck, A.M., and Meheust, A. (2010). Prebiotic effects: metabolic and health benefits. Br. J. Nutr 104(Suppl 2): S1-63.

Rocha, J., Eduardo-Figueira, M., Barateiro, A., Fernandes, A., Brites, D. Bronze, R., Duarte, C.M., Serra, A.T., Pinto, R., Freitas, M., Fernandes, E., Silva-Lima, B., Mota-Filipe, H., and Sepodes, B. (2015). Anti-inflammatory effect of rosmarinic acid and an extract of Rosmarinus officinalis in rat models of local and systemic inflammation. Basic Clin. Pharmacol. Toxicol. 16(5): 398-413.

Roussel, A.M., Hininger, I., Benaraba, R., Ziegenfuss, T.N., and Anderson, R.A. (2009). Antioxidant effects of a cinnamon extract in people with impaired fasting glucose that are overweight or obese. J. Am. Coll. Nutr. 28(1): 16-21.

Ruby, B.C., Gaskill, S.E., Slivka, D., and Harger, S.G. (2005). The addition of fenugreek extract (Trigonella foenum-gracum) to glucose feeding increases muscle glycogen resynthesis after exercise. Amino Acids. 28(1): 71-76

Saleem, S., Ahmad, M., Ahmad, A.S., Yousuf, S., Ansari, M.A., Khan, M.B. Ishrat, T., and Islam, F. (2006). Behavioral and histologic neuroprotection of aqueous garlic extract after reversible focal cerebral ischemia. J. Med. Food. 9(4): 537-544.

Salman, H., Bergman, M., Bessler, H., Punsky, I., and Djaldetti, M. (1999). Effect of a garlic derivative (alliin) on peripheral blood cell immune responses. Int. J. Immunopharmacol. 21(9): 589-597.

Saito, M., and Yoneshiro, T. (2013). Capsinoids and related food ingredients activating brown fat thermogenesis and reducing body fat in humans. Curr. Opin. Lipidol. 24(1): 71-77.
Salimzadeh, A., Alipoor, E., Dehghani, S., Yaser, M., Hosseini, M., FeinieBisset, C., and Hosseinzadeh-Attar, M.J. (2018). The effect of 12-week garlic supplementation on symptom relief in overweight or obese women with knee osteoarthritis. Int. J. Clin. Pract. 72(6): e13208.

Sang, S., Hong, J., Wu, H., Liu, J., Yang, C.S., Pan, M.H., Badmaev, V., and Ho, C.T. (2009). Increased growth inhibitory effects on human cancer cells and anti-inflammatory potency of shogaols from Zingiber officinale relative to gingerols. J. Agric. Food Chem. 57(22): 10645-10650.

Santos, F.A., Silva, R.M., Tomé, A.R., Rao, V.S., Pompeu, M.M., Teixeira M.J., De Freitas, L.A., and De Souza, V.L. (2001). 1,8-cineole protects against liver failure in an in vivo murine model of endotoxemic shock. J. Pharm. Pharmacol. 53(4): 505-511.

Santos-Parker, J.R., Strahler, T.R., Bassett, C.J., Bispham, N.Z., Chonchol, M.B., and Seals, D.R. (2017). Curcumin supplementation improves vascular endothelial function in healthy middle-aged and older adults by increasing nitric oxide bioavailability and reducing oxidative stress. Aging. 9(1): 187-208.

Saraswat, M., Reddy, P.Y., Muthenna, P., and Reddy, G.B. (2009). Prevention of non-enzymic glycation of proteins by dietary agents: prospects for alleviating diabetic complications. Br. J. Nutr. 101(11): 1714-1721.

Sarbini, S., and Rastall, R.A. (2011). Prebiotics: metabolism, structure, and function. Functional Food Reviews. 3(3): 93-106.

Satoh, T., Kosaka, K., Itoh, K., Kobayashi, A., Yamamoto, M., Shimojo, Y., Kitajima, C., Cui, J., Kamins, J., Okamoto, S., Izumi, M., Shirasawa, T., and Lipton, S.A. (2008). Carnosic acid, a catechol-type electrophilic compound, protects neurons both in vitro and in vivo through activation of the Keap1/Nrf2 pathway via S-alkylation of targeted cysteines on Keap1. J. Neurochem. 104(4): 1116-1131.

Satyanarayana, M.N. (2006). Capsaicin and gastric ulcers. Crit. Rev. Food Sci. Nutr. 46(4): 275-328.

Scharbert, G., Kalb, M.L., Duris, M., Marschalek, C., and Kozek-Langeneckey, S.A. (2007). Garlic at dietary doses does not impair platelet function. Anesth Analg. 105(5): 1214-1218.

Scheckel, K.A., Degner, S.C., and Romagnolo, D.F. (2008). Rosmarinic acid antagonizes activator protein-1-dependent activation of cyclooxygenase- 2 expression in human cancer and nonmalignant cell lines. J. Nutr. 138(11): 2098-2105.

Scheerens, J.C. (2001). Phytochemicals and the consumer: Factors affecting fruit and vegetable consumption and the potential for increasing small fruit in the diet. Hort. Technolgy 11: 547-556.

Schmitz, K., Barthelmes, J., Stolz, L., Beyer, S., Diehl, O., and Tegeder, I. (2015). "Disease modifying nutricals" for multiple sclerosis. Pharmacol. Ther. 148: 85-113.

Seo, J.S., Burri, B.J., Quan, Z., and Neidlinger, T.R. (2005). Extraction and chromatography of carotenoids from pumpkin. J. Chromatogr. A. 1073(1-2): 371-375.

Serafini, M., and Peluso, I. (2016). Functional foods for health: The interrelated antioxidant and anti-inflammatory role of fruits, vegetables, herbs, spices and cocoa in humans. Curr. Pharm. Des. 22(44): 67016715.

Shabbeer, S., Sobolewski, M., Anchoori, R.K., Kachhap, S., Hidalgo, M., Jimeno, A., Davidson, N., Carducci, M.A., and Khan, S.R. (2009). Fenugreek: A naturally occurring edible spice as an anticancer agent. Cancer Biol. Ther. 8(3): 272-278

Shahidi, F., and Hossain, A. (2018). Bioactives in spices and spice oleoresins: Phytochemicals and their biological effects in food preservation and health promotion. J. Food Bioact. 3: 8-75.

Shahidi, F., and Peng, H. (2018). Bioaccessibility and bioavailability of phenolic compounds. J. Food Bioact 4: 11-68.

Shahidi, F., and Ambigaipalan, P. (2015). Phenolics and polyphenolics in food, beverages and spices: Antioxidant activity and health effects - A review. J. Funct. Foods 18: 820-897.

Shamshad Begum, S., Jayalakshmi, H.K., Vidyavathi, H.G., Gopakumar, G., Abin, I., Balu, M., Geetha, K., Suresha, S.V., Vasundhara, M., and Krishnakumar, I.M. (2016). A novel extract of fenugreek husk (FenuSMART ${ }^{\mathrm{TM}}$ ) alleviates postmenopausal symptoms and helps to establish the hormonal balance: A randomized, double-blind, placebocontrolled study. Phytother. Res. 30(11): 1775-1784.

Shan, B., Cai, Y.Z., Sun, M., and Corke, H. (2005). Antioxidant capacity of 26 spice extracts and characterization of their phenolic constituents. J. Agric. Food. Chem. 53(20): 7749-7759. 
Shannahan, F. (2015). Fibre man meets microbe man. Am. J. Clin. Nutr. 101: 1-2.

Shin, N.R., Kwon, O.K., Kim, H.S., Kim, J.C., Oh, S.R., and Ahn, K.S. (2013). Diallyl-disulfide, an organosulfur compound of garlic, attenuates airway inflammation via activation of the Nrf-2/HO-1 pathway and NFkappaB suppression. Food Chem. Toxicol. 62: 506-513.

Shidfar, F., Rajab, A., Rahideh, T., Khandouzi, N., Hosseini, S., and Shidfar, S. (2015). The effect of ginger (Zingiber officinale) on glycemic markers in patients with type 2 diabetes. J. Complement. Integr. Med. 12(2): 165-170.

Shoba, G., Joy, D., Joseph, T., Majeed, M., Rajendran, R., and Srinivas, P.S. (1998). Influence of piperine on the pharmacokinetics of curcumin in animals and human volunteers. Planta Med. 64(4): 353-356

Simons, S., Wollersheim, H., and Thien, T. (2009). A systematic review on the influence of trial quality on the effect of garlic on blood pressure. Neth. J. Med. 67(6): 212-219.

Simpson, H.L., and Campbell, B.J. (2015). Review article: dietary fibre-microbiota interactions. Aliment. Pharmacol. Ther. 42(2): 158-179.

Slivka, D., Cuddy, J., Hailes, W., Harger, S., and Ruby, B. (2008). Glycogen resynthesis and exercise performance with the addition of fenugreek extract (4-hydroxyisoleucine) to post-exercise carbohydrate feeding. Amino Acids. 35(2): 439-444.

Smith, C., Crowther, C., Willson, K., Hothham, N., and McMillian, V. (2004). A randomized controlled trial of ginger to treat nausea and vomiting in pregnancy. Obstet. Gynecol. 103(4): 639-645.

Snitker, S., Fujishima, Y., Shen, H., Ott, S., Pi-Sunyer, X., Furuhata, Y., Sato, H., and Takahashi, M. (2009). Effects of novel capsinoid treatment on fatness and energy metabolism in humans: possible pharmacogenetic implications. Am. J. Clin. Nutr. 89(1): 45-50.

Sobenin, I.A., Nedosugova, L.V., Filatova, L.V., Balabolkin, M.I., Gorchakova, T.V., and Orekhov, A.N. (2008). Metabolic effects of time-released garlic powder tablets in type 2 diabetes mellitus: the results of double-blinded placebo-controlled study. Acta Diabetol. 45(1): 1-6.

Solomon, T.P., and Blannin, A.K. (2007). Effects of short-term cinnamon ingestion on in vivo glucose tolerance. Diabetes Obes. Metab. 9(6): 895-901.

Solomon, T.P., and Blannin, A.K. (2009). Changes in glucose tolerance and insulin sensitivity following 2 weeks of daily cinnamon ingestion in healthy humans. Eur. J. Appl. Physiol. 105(6): 969-976.

Soni, K.B., and Kuttan, R. (1992). Effect of oral curcumin administration on serum peroxides and cholesterol levels in human volunteers. Indian J. Physiol. Pharmacol. 36(4): 273-275.

Sowmya, P., and Rajyalakshmi, P. (1999). Hypocholesterolemic effect of germinated fenugreek seeds in human subjects. Plant Foods Hum. Nutr. 53(4): 359-365.

Spiller, F., Alves, M.K., Vieira, S.M., Carvalho, T.A., Leite, C.E., Lunardelli, A., Poloni, J.A., Cunha, F.Q., and de Oliveira, J.R. (2008). Anti-inflammatory effects of red pepper (Capsicum baccatum) on carrageenan- and antigen-induced inflammation. J. Pharm. Pharmacol. 60(4): 473-478.

Srichamroen, A., Field, C.J., Thomson, A.B., and Basu, T.K. (2008). The modifying effects of galactomannan from Canadian-grown fenugreek (Trigonella foenum-graecum L.) on the glycemic and lipidemic status in rats. J. Clin. Biochem. Nutr. 43(3): 167-174.

Srichamroen, A., Thomson, A.B., Field, C.J., and Basu, T.K. (2009). In vitro intestinal glucose uptake is inhibited by galactomannan from Canadian fenugreek seed (Trigonella foenum graecum $\mathrm{L}$ ) in genetically lean and obese rats. Nutr. Res. 29(1): 49-54.

Srinivasan, K. (2007). Black pepper and its pungent principle-piperine: a review of diverse physiological effects. Crit. Rev. Food Sci. Nutr. 47(8): 735-748.

Srinivasan, S., Koduru, S., Kumar, R., Venguswamy, G., Kyprianou, N., and Damodaran, C. (2009). Diosgenin targets Akt-mediated prosurvival signaling in human breast cancer cells. Int. J. Cancer. 125(4): 961967.

Srinivasan, K. (2013). Dietary spices as beneficial modulators of lipid profile in conditions of metabolic disorders and diseases. Food Funct. 4(4): 503-521.

Srivastava, G., and Mehta, J.L. (2009). Currying the heart: curcumin and cardioprotection. J. Cardiovasc. Pharmacol. Ther. 14(1): 22-27.

Steels, E., Rao, A., and Vitetta, L. (2011). Physiological aspects of male libido enhanced by standardized Trigonella foenum-graecum extract and mineral formulation. Phytother. Res. 25(9): 1294-300

Steels, E., Steele, M.L., Harold, M., and Coulson, S. (2017). Efficacy of a proprietary Trigonella foenum-graecum L. de-husked seed extract in reducing menopausal symptoms in otherwise healthy women: $\mathrm{A}$ double-blind, randomized, placebo-controlled study. Phytother. Res. 31(9): 1316-1322.

Steiner, M., and Li, W. (2001). Aged garlic extract, a modulator of cardiovascular risk factors: a dose-finding study on the effects of AGE on platelet functions. J. Nutr. 131(3s): 980S-984S.

Sun, G.Y., Chen, Z., Jasmer, K.J., Chuang, D.Y., Gu, Z., Hannink, M., and Simonyi, A. (2015). Quercetinattenuates inflammatory responses in BV-2 microglial cells: role of MAPKs on the Nrf2 pathway and induction of heme oxygenase-1. PLoS ONE. 10(10): e0141509.

Sung, B., Prasad, S., Yadav, V.R., and Aggarwal, B.B. (2012). Cancer cell signaling pathwaystargeted by spice-derived nutraceuticals. Nutr. Cancer. 64(2): 173-197.

Surh, Y. (1999). Molecular mechanisms of chemopreventive effects of selected dietary and medicinal phenolic substances. Mutat. Res. 428(1 2): 305-27.

Suppapitiporn, S., Kanpaksi, N., and Suppapitiporn, S. (2006). The effect of cinnamon cassia powder in type 2 diabetes mellitus. J. Med. Assoc. Thai. 89(Suppl 3): S200-S205.

Szulińska, M., Kręgielska-Narożna, M., and Świątek, J. (2018). Garlic extract favorably modifies markers of endothelial function in obese patients - randomized double-blind placebo-controlled nutritional intervention. Biomed. Pharmacother. 102: 792-797.

Tapsell, L.C., Hemphill, I., Cobiac, L., Patch, C.S., and Sullivan, D.R. (2006). Health benefits of herbs and spices: the past, the present, the future. The Medical J. Australia 185(4 Suppl): S1-S24.

Tasleem, F., Azhar, I., Ali, S.N., Perveen, S., and Mahmood, Z.A. (2014). Analgesic and anti-inflammatory activities of Piper nigrum L. Asian Pac. J. Trop. Med. (Suppl 1): 461-468.

Thomson, M., Al-Qattan, K.K., Bordia, T., and Ali, M. (2006). Including garlic in the diet may help lower blood glucose, cholesterol, and triglycerides. J. Nutr. 136(3 Suppl): 800S-802S.

Tomé-Carneiro, J., and Visioli, F. (2016). Polyphenol-based nutraceuticals for the prevention and treatment of cardiovascular disease: Review of human evidence. Phytomedicine. 23(11): 1145-1174.

Tsui, P.F., Chin-Sheng Lin, C.S., Ling-Jun Ho, L.J., and Jenn-Haung Lai, J.H. (2018). Spices and atherosclerosis. Nutrients. 10(11): 1724.

Tzeng, T.F., Liou, S.S., Chang, C.J., and Liu, I.M. (2015). 6-gingerol protects against nutritional steatohepatitis by regulating key genes related to inflammation and lipid metabolism. Nutrients. 7(2): 999-1020.

Tzounis, X., Rodriguez-Mateos, A., Vulevic, J., Gibson, G.R., Kwik-Uribe, C., and Spencer, J.P.E. (2011). Prebiotic evaluation of cocoa-derived flavanols in healthy humans by using a randomized, controlled, doubleblind, crossover intervention study. Am. J. Clin. Nutr. 93: 62-72.

Umar, S., Golam Sarwar, A.H., Umar, K., Ahmad, N., Sajad, M., Ahmad, S., Katiyar, C.K., and Khan, H.A. (2013). Piperine ameliorates oxidative stress, inflammation and histological outcome in collagen induced arthritis. Cell Immunol. 284(1-2): 51-59.

Usharani, P., Mateen, A.A., Naidu, M.U., Raju, Y.S., and Chandra, N. (2008) Effect of NCB-02, atorvastatin and placebo on endothelial function, oxidative stress and inflammatory markers in patients with type 2 diabetes mellitus: a randomized, parallel-group, placebo-controlled, 8-week study. Drugs R D. 9(4): 243-250.

Vaibhav, K., Shrivastava, P., Javed, H., Khan, A., Ahmed, M.E., Tabassum, R., Khan, M.M., Khuwaja, G., Islam, F., Siddiqui, M.S., Safhi, M.M., and Islam, F. (2012). Piperine suppresses cerebral ischemia-reperfusioninduced inflammation through the repression of COX-2, NOS-2, and NF-KB in middle cerebral artery occlusion rat model. Mol. Cell Biochem. 367(1-2): 73-84.

Vaidya, V., Ingold, K.U., and Pratt, D.A. (2009). Garlic: source of the ultimate antioxidants--sulfenic acids. Angew Chem. Int. Ed. Engl. 48(1) $157-160$

Vandeputte, D., Falony, G., Vieira-Silva, S., Wang, J., Sailer, M., Theis, S., Verbeke, K., and Raes, J. (2016). Prebiotic inulin-type fructans induce specific changes in the human gut microbiota. Gut. 66(11): 19681974.

Varma, J. https://www.grandviewresearch.com/.

Varshney, R., and Budoff, M.J. (2016). Garlic and heart disease. J. Nutr. 
146(2): 416S-421S

Verspreet, J., Damen, B., Broekaert, W.F., Verbeke, K., Delcour, J.A., and Courtin, C.M. (2016). A critical look at prebiotics within the dietary fiber concept. Ann. Rev. Food Sci. Technol. 7: 167-190.

Vijayakumar, R.S., and Nalini, N. (2006a). Efficacy of piperine, an alkaloidal constituent from Piper nigrum on erythrocyte antioxidant status in high fat diet and antithyroid drug induced hyperlipidemic rats. Cell Biochem. Funct. 24(6): 491-498.

Vijayakumar, R.S., and Nalini, N. (2006b). Piperine, an active principle from Piper nigrum, modulates hormonal and apo lipoprotein profiles in hyperlipidemic rats. J. Basic Clin. Physiol. Pharmacol. (2): 71-86.

Vijayalakshmi, A., Ravichandiran, V., Malarkodi, V., Nirmala, S., and Jayakumari, S. (2012). Screening of flavonoid "quercetin" from the rhizome of Smilax china Linn. For anti-psoriatic activity. Asian Pac. J. Trop Biomed. 2(4): 269-275.

Visalyaputra, S., Petchpaisit, N., Somcharoen, K., and Choavaratana, S. (1998). The efficacy of ginger root in the prevention of postoperative nausea and vomiting after outpatient gynaecological laparoscopy. Anaesthesia. 53(5): 506-510.

Vulevic, J., Juric, A., Walton, G.E., Claus, S.P., Tzortzis, G., Toward, R.E., and Gibson, G.R. (2015). Influence of galacto-oligosaccharide mixture (BGOS) on gut microbiota, immune parameters and metabonomics in elderly persons. Br. J. Nutr. 114(4): 586-595.

Wakade, C., King, M.D., Laird, M.D., Alleyne, C.H., and Dhandapani, K.M. (2009). Curcumin attenuates vascular inflammation and cerebral vasospasm after subarachnoid hemorrhage in mice. Antioxid. Redox Signal. 11(1): 35-45.

Wang, L., and Bohn, T. Health-Promoting Food Ingredients and Functional Food Processing, Nutrition, Well-Being and Health, Jaouad Bouayed and Torsten Bohn, IntechOpen. Available from: https://www.intechopen.com/books/nutrition-well-being-and-health/health-promoting-food-ingredients-development-and-processing.

Wang, J., Zhang, X., Lan, H., and Wang, W. (2017). Effect of garlic supplement in the management of type 2 diabetes mellitus (T2DM): a meta-analysis of randomized controlled trials. Food Nutr. Res. 61(1): 1377571.

Wang, S.L., Li, Y., Wen, Y., Chen, Y.F., Na, L.X., Li, S.T., and Sun, C.H. (2009). Curcumin, a potential inhibitor of up-regulation of TNF-alpha and IL-6 induced by palmitate in 3T3-L1 adipocytes through NF-kappaB and JNK pathway. Biomed. Environ. Sci. 22(1): 32-39.

Wani, S.A., and Kumar, P. (2018). Fenugreek: A review on its nutraceutical properties and utilization in various food products. J. Saudi Soc. Agr. Sci. 17(2): 97-106.

Watson, R., and Preedy, V. (2012). Bioactive Food as Dietary Interventions for Cardiovascular Disease. Elsevier, Academic Press, NY, p. 746.

Westerterp-Plantenga, M., Diepvens, K., Joosen, A.M., Berube-Parent, S., and Tremblay, A. (2006). Metabolic effects of spices, teas, and caffeine. Physiol. Behav. 89(1): 85-91.

Westerterp-Plantenga, M.S., Smeets, A., and Lejeune, M.P. (2005). Sensory and gastrointestinal satiety effects of capsaicin on food intake. Int. J. Obes (Lond.). 29(6): 682-688.

Wijeratne, S.S., and Cuppett, S.L. (2007). Potential of rosemary (Rosemarinus officinalis L.) diterpenes in preventing lipid hydroperoxidemediated oxidative stress in Caco-2 cells. J. Agric. Food Chem. 55(4): 1193-1199.

Wilborn, C., Taylor, L., Poole, C., Foster, C., Willoughby, D., and Kreider, R. (2010). Effects of a purported aromatase and $5 \alpha$-reductase inhibitor on hormone profiles in college-age men. Int. J. Sport Nutr. Exerc. Metab. 20(6): 457-465.

Williams, M.J., Sutherland, W.H., McCormick, M.P., Yeoman, D.J., and de Jong, S.A. (2005). Aged garlic extract improves endothelial function in men with coronary artery disease. Phytother. Res. 19(4): 314-9.

Williamson, G. (2017). The role of polyphenols in modern nutrition - A review. Special issue: Nutrition science past and future: Celebrating a multidisciplined approach. Nut. Bulletin. 42(3): 226-235.

Wojcikowski, K., Myers, S., and Brooks, L. (2007). Effects of garlic oil on platelet aggregation: a double-blind placebo-controlled crossover study. Platelets. 18(1): 29-34.

Womack, C.J., Lawton, D.J., Redmond, L., Todd, M.K., and Hargens, T.A. (2015). The effects of acute garlic supplementation on the fibrinolytic and vasoreactive response to exercise. J. Int. Soc. Sports Nutr. 12: 23.
Worthley, D.L., Leu, R.K.L., Whitehall, V.L., Conlon, M., Christophersen, C., Belobrajdic, D., Mallitt, K.A., Hu, Y., Irahara, N., Ogino, S., Leggett, B.A., and Young, G.P. (2009). A human, double-blind, placebo-controlled, crossover trial of prebiotic, probiotic, and synbiotic supplementation: effects on luminal, inflammatory, epigenetic, and epithelial biomarkers of colorectal cancer. Am. J. Clin. Nutr. 90: 578-586.

Woo, H.M., Kang, J.H., Kawada, T., Yoo, H., Sung, M.K., and Yu, R. (2007). Active spice-derived components can inhibit inflammatory responses of adipose tissue in obesity by suppressing inflammatory actions of macrophages and release of monocyte chemoattractant protein-1 from adipocytes. Life Sci. 80(10): 926-631.

Xia, Y., Khoi, P.N., Yoon, H.J., Lian, S., Joo, Y.E., Chay, K.O., Kim, K.K., and Jung, Y.D. (2015). Piperine inhibits IL-1 $\beta$-induced IL-6 expression by suppressing p38 MAPK and STAT3 activation in gastric cancer cells. Mol. Cell. Biochem. 398(1-2): 147-156.

Yadav, V.R., Prasad, S., Sung, B., Kannappan, R., and Aggarwal, B.B. (2010). Targeting inflammatory pathways by triterpenoids for prevention and treatment of cancer. Toxins (Basel). 2(10): 2428-2466.

Yang, F., Lim, G.P., Begum, A.N., Ubeda, O.J., Simmons, M.R., Ambegaokar, S.S., Chen, P.P., Kayed, R., Glabe, C.G., Frautschy, S.A., and Cole, G.M (2005). Curcumin inhibits formation of amyloid beta oligomers and fibrils, binds plaques, and reduces amyloid in vivo. J. Biol. Chem. 280(7): 5892-5901.

Yashin, A., Yashin, Y., Xia, X., and Nemzer, B. (2017). Antioxidant activity of spices and their impact on human health: A review. Antioxidants (Basel). 6(3): 18

Yeoh, K.G., Kang, J.Y., Yap, I., Guan, R., Tan, C.C., Wee, A., and Teng, C.H. (1995). Chili protects against aspirin-induced gastroduodenal mucosal injury in humans. Dig. Dis. Sci. 40(3): 580-583.

Yoshioka, M., St-Pierre, S., Suzuki, M., and Tremblay, A. (1998). Effects of red pepper added to high-fat and high-carbohydrate meals on energy metabolism and substrate utilization in Japanese women. Br. J. Nutr. 80(6): 503-510.

Young, A.J., and Low, G.M. (2001). Antioxidants and prooxidant properties of carotenoids. Archived Biochem Biophysics 385: 20-27.

Young, H.Y., Liao, J.C., Chang, Y.S., Luo, Y.L., Lu, M.C., and Peng, W.H. (2006). Synergistic effect of ginger and nifedipine on human platelet aggregation: a study in hypertensive patients and normal volunteers. Am. J. Chin. Med. 34(4): 545-551

Yuan, L.J., Qin, Y., Wang, L., Zeng, Y., Chang, H., Wang, J., Wang, B., Wan, J., Chen, S.H., Zhang, Q.Y., Zhu, J.D., Zhou, Y., and Mi, M.T. (2016). Capsaicin-containing chili improved postprandial hyperglycemia, hyperinsulinemia, and fasting lipid disorders in women with gestational diabetes mellitus and lowered the incidence of large-for-gestationalage newborns. Clin. Nutr. 35(2): 388-393.

Zaidi, S.F., Yamada, K., Kadowaki, M., Usmanghani, K., and Sugiyama, T. (2009). Bactericidal activity of medicinal plants, employed for the treatment of gastrointestinal ailments, against Helicobacter pylori. J. Ethnopharmacol. 121(2): 286-291.

Zanzer, Y.C., Plaza, M., Douglas, A., Turner, C., and Östman, E. (2018). Black pepper-based beverage induced appetite-suppressing effects without altering postprandial glycaemia, gut and thyroid hormones or gastrointestinal well-being: a randomized crossover study in healthy subjects. Food Funct. 9(5): 2774-2786.

Zick, S.M., Ruffin, M.T., Lee, J., Normolle, D.P., Siden, R., Alwari, S., and Brenner, D.E. (2009). Phase II trial of encapsulated ginger as a treatment for chemotherapy-induced nausea and vomiting. Support Care Cancer. 17(5): 563-572.

Zhao, Y., Chen, B., Shen, J., Wan, L., Zhu, Y., Yi, T., and Xiao, Z. (2017). The beneficial effects of quercetin, curcumin and resveratrol in obesity. Oxid. Med. Cell Longev. 2017: 1459497.

Zhai, W.J., Zhang, Z.B., Xu, N.N., Guo, Y.F., Qiu, C., Li, C.Y., Deng, G.Z., and Guo, M.Y. (2016). Piperine Plays an Anti-Inflammatory Role in Staphylococcus aureus Endometritis by Inhibiting Activation of NF-KB and MAPK Pathways in Mice. Evid. Based Complement Alternat Med. 2016: 8597208

Zhang, C., Browne, A., Child, D., and Tanzi, R.E. (2010). Curcumin decreases amyloid-beta peptide levels by attenuating the maturation of amyloid-beta precursor protein. J. Biol. Chem. 285(37): 28472-28480.

Zhang, L.L., Liu, D.Y., Ma, L.Q., Luo, Z.D., Cao, T.B., Zhong, J., Yan, Z.C., Wang, L.J., Zhao, Z.G., Zhu, S.J., Schrader, M., Thilo, F., Zhu, Z.M., and 
Tepel, M. (2007). Activation of transient receptor potential vanilloid type-1 (TRPV1) channel prevents adipogenesis and obesity. Circ Res. 100(7): 1063-1070.

Zheng, J., Zhou, Y., Li, Y., Xu, D.P., Li, S., and Li, H.B. (2016). Spices for prevention and treatment of cancers. Nutrients 8(8): E495.

Zhu, R., Liu, H., Liu, C., Wang, L., Ma, R., Chen, B., Li, L., Niu, J., Fu, M.,
Zhang, D., and Gao, S. (2017). Cinnamaldehyde in diabetes: A review of pharmacology, pharmacokinetics and safety. Pharmacol. Res. 122: 78-89.

Zsombok, A. (2013). Vanilloid receptors - do they have a role in whole body metabolism? Evidence from TRPV1. J. Diabetes Complications. 27(3): 287-292. 